UNIVERSIDADE DE SÃO PAULO

PROGRAMA DE PÓS GRADUAÇÃO INTERUNIDADES

EM ESTÉTICA E HISTÓRIA DA ARTE

\title{
ITINERÁRIO, ESTUDO ESTÉTICO E ESTILÍSTICO DE UMA ESCULTURA DOGON: "FIGURA HERMAFRODITA" DO MESTRE DE YAYÉ
}

Jair Guilherme Filho

\author{
Dissertação apresentada ao Programa \\ de Pós-Graduação Interunidades na Área de \\ Concentração de Estética e História da Arte da \\ Universidade de São Paulo, como exigência \\ parcial para obtenção do Título de Mestre em \\ Estética e História da Arte, sob orientação da \\ Prof. Dra. Dilma de Melo Silva.
}

SÃO PAULO

2014 
AUTORIZO A REPRODUÇÃO E DIVULGAÇÃO TOTAL E PARCIAL DESTE TRABALHO, POR QUALQUER MEIO CONVENCIONAL OU ELETRÔNICO, PARA FINS DE ESTUDO E PESQUISA, DESDE QUE CITADA A FONTE.

Catalogação da Publicação

Biblioteca Lourival Gomes Machado

Museu de Arte Contemporânea da Universidade de São Paulo

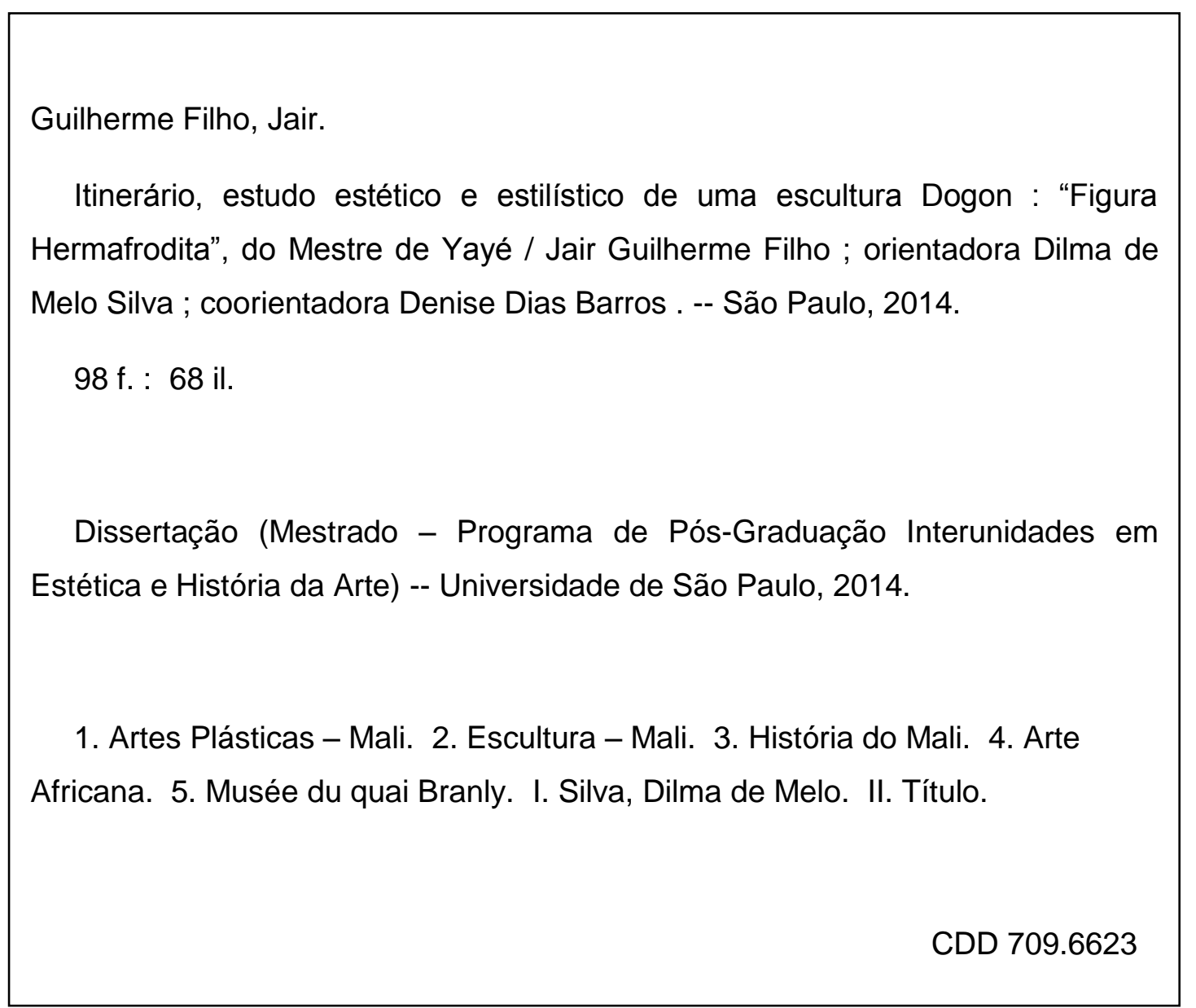


GUILHERME FILHO, Jair. Dissertação apresentada ao Programa de Pós-Graduação Interunidades em Estética e História da Arte da Universidade de São Paulo para a obtenção do título de Mestre em História da Arte.

Aprovado em :

\section{Banca Examinadora}

Prof Dra. Dilma de Melo Silva

Julgamento:

Prof Dra. Denise Dias Barros

Julgamento:

Prof Dra. Alecsandra Matias de Oliveira

Julgamento:
Instituição: Universidade de São Paulo

Assinatura:

Instituição: Universidade de São Paulo

Assinatura:

Instituição: Universidade de São Paulo

Assinatura: 


\section{Aos Professores}

Dilma de Melo Silva, por me trazer de volta à Escola.

Denise Dias Barros, por me ensinar a entender arte dos "outros".

Francisco Alberto Rocha, por me indicar o retorno ao conhecimento.

Ednilson Quarenta, pela iminente parceria.

\section{Aos meus pais}

Jair e Cecília pela alegria de viver...

\section{Aos meus irmãos}

Carlos, Clarice, Waldir, Dario, (Maria e Mário)

por me ensinar a dividir o pão.

\section{A todos os meus parentes e agregados!!!}

A todos os meus Amigos!!!

A todos os meus alunos!!!

\section{À Secretaria do PGEHA:}

Águida, Joana e Paulo pela atenção, cordialidade e competência. 
Meus agradecimentos especiais aos professores, aos programas e às unidades de pesquisas:

Professora Dra. Dilma de Melo Silva,

Professora Dra. Denise Dias Barros,

Professora Dra. Marta Heloisa Leuba Salum,

Professora Dra. Carmem Sylvia Guimarães Aranha,

Professora Dra. Alecsandra Matias de Oliveira,

Professora Dra. Maria Luisa Sandoval Schimdt,

Professor Dr. Artur Matuck,

Professor Dr. Ednilson Quarenta,

Professor Dr. Victor Martins,

Professor Dr. Kabengele Munanga,

Professora Karina Silemen,

Professora Simone Triantafyllou,

PGEHA INTERUNIDADES, ECA-USP, CAPES, PRCEU-USP, CEA-USP, CASA DAS ÁFRICAS, ACERVO ÁFRICAS e EMEF MAURO FACCIO GONÇALVES "ZACARIA" 


\section{Resumo}

A Escultura Dogon, produzida no Mali, ao noroeste do continente africano, constitui um dos mais importantes acervos das artes africanas, recolhidos a partir das Missões coloniais EtnológicasEtnográficas coordenadas por Marcel Griaule desde 1931. ITINERÁRIO, ESTUDO ESTÉTICO E ESTILÍSTICO DE UMA ESCULTURA DOGON: "FIGURA HERMAFRODITA" DO MESTRE DE YAYÉ, trata da construção de uma análise dos estilos dessa arte estatuária assim como a análise específica sobre o percurso da peça em questão, desde o vilarejo de Yayé em Bandiagara, no Mali, até o acervo do museu du Quai Branly, na cidade de Paris, França. O objetivo dessa pesquisa foi fortalecer os estudos sobre a Arte Africana no Brasil, contribuindo para o conhecimento da sociedade Dogon a partir de sua expressão artística, e como pensar a Arte Africana e a África a partir de sua produção estética.

Palavras-chave: Arte Africana, Arte Etnológica, Escultura Dogon,

Figura Hermafrodita Niongom, Yayé, Trocadero, Museu do Louvre, Museu do Quai Branly. 


\section{Abstract}

The Dogon sculpture, produced in Mali, northwest of the african continent, is one of the most important collections of African art, collected from the Colonial Missions Ethnological-Ethnographic coordinated by Marcel Griaule since 1931. ITINERARY, AESTHETIC AND STYLISTIC STUDY OF A SCULPTURE DOGON "HERMAPHRODITE FIGURE" THE MASTER OF YAYÉ, is the construction of an analysis of styles such statuary as well as specific analysis on the route of the piece in question, from the village of Yayé in Bandiagara, Mali to the museum's collection du Quai Branly, in Paris, France. The objective of this research was to strengthen the studies on African Art in Brazil, contributing to the knowledge of the Dogon society from their artistic expression, and how to think African Art and Africa from its aesthetic production.

Keywords: African Arts Ethnological Art, Sculpture Dogon Figure Hermaphrodite Niongom, Yaye, Trocadero, the Louvre, the Quai Branly Museum. 


\section{Lista das Figuras}

Fig. 01 - Detalhe da fotografia de Hughes Dubois (Museu do Quai Branly) …….................................................15

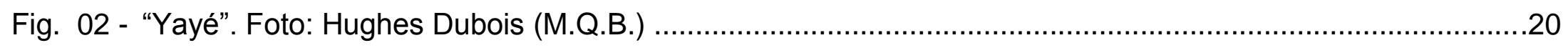

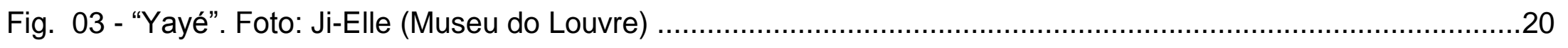

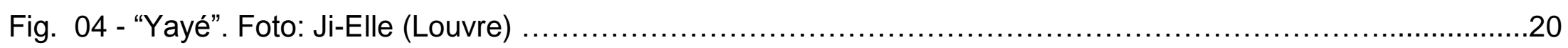

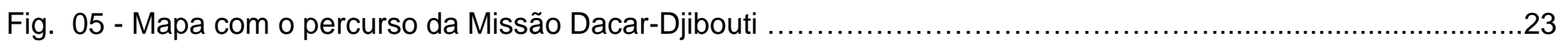

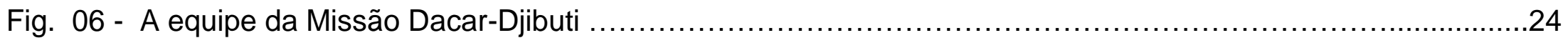

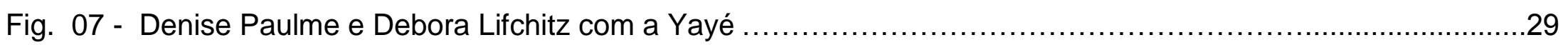

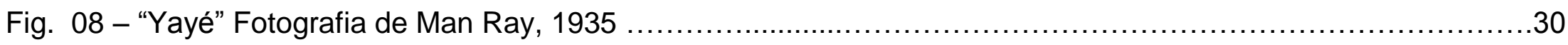

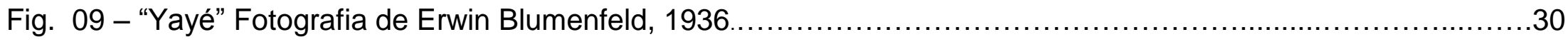

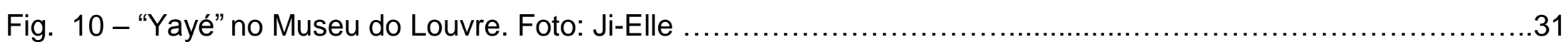

Fig. 11 - Visitante diante da vitrine com o conjunto de esculturas Niongom.........................................................37

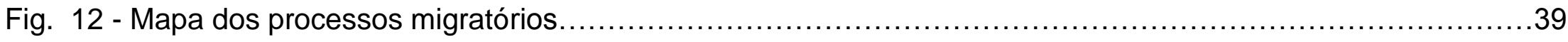

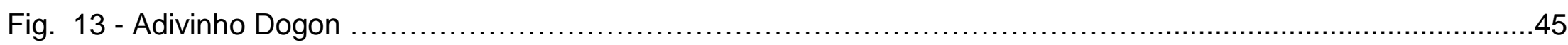

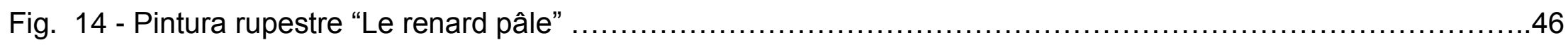

Fig. 15 - Ilustração do livro "O caçador de nuvens” ……….................................................................................47

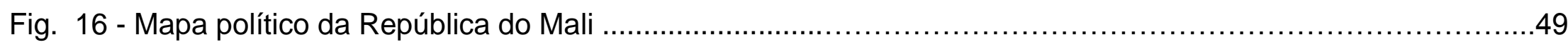

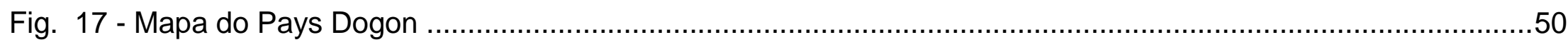

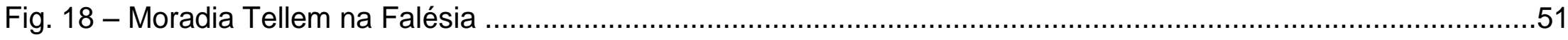


Fig. 19 - A Planície. Foto: Timm Guernthe

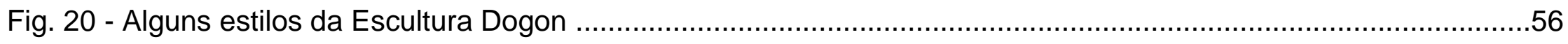

Fig. 21 - Mapa da localização dos estilos de esculturas no país Dogon...............................................................58

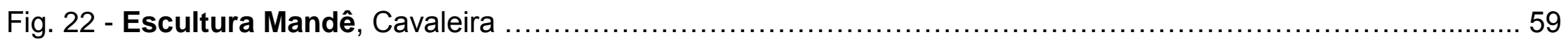

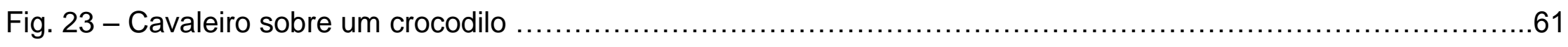

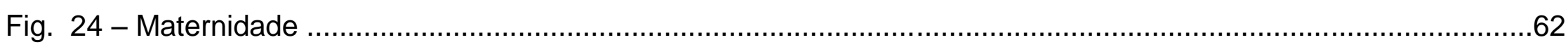

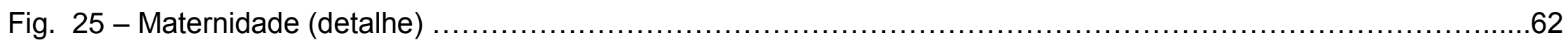

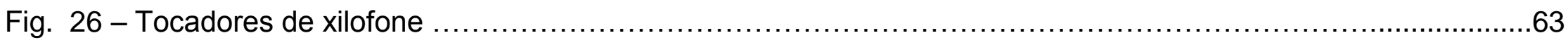

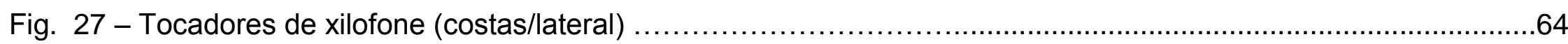

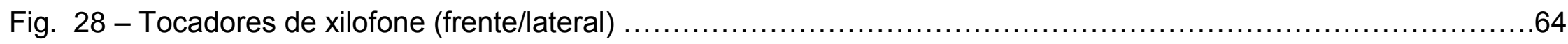

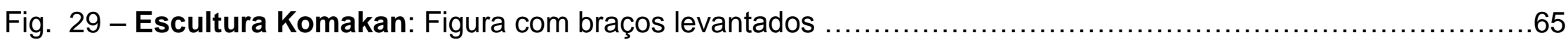

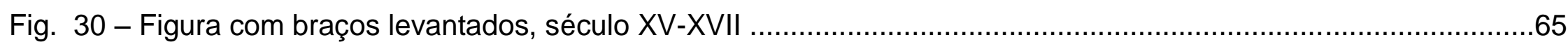

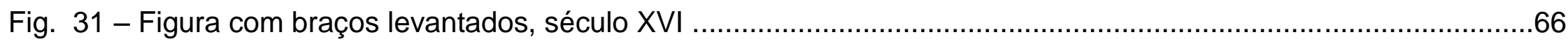

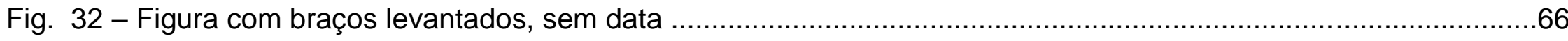

Fig. 33 - Escultura Tellem: Figura com braços levantados, século XVI ....................................................67

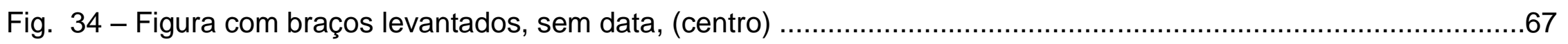

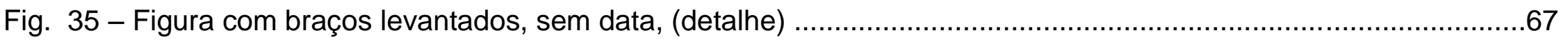

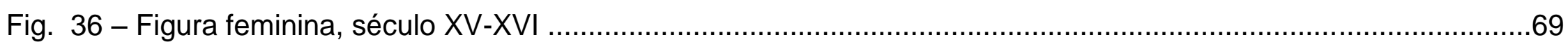

Fig. 37 - Figura feminina com braços levantados, sem data, (detalhe) …...................................................69

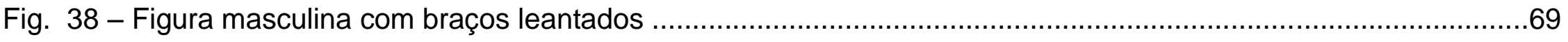


Fig. 39 - Escultura Niongom: Figura hermafrodita, século XV-XVI

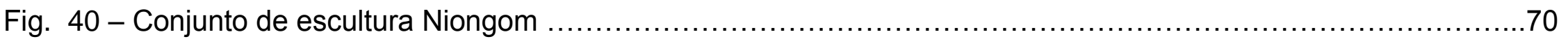

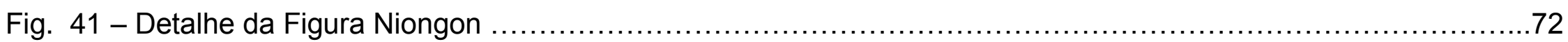

Fig. 42- Escultura Bombou-Toro: Figura feminine, atelier do Mestre de Ogol, (detalhe) ............................

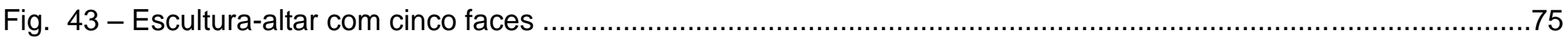

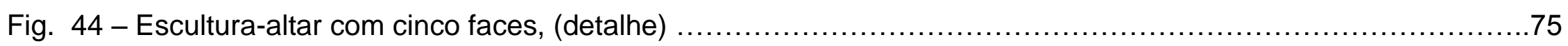

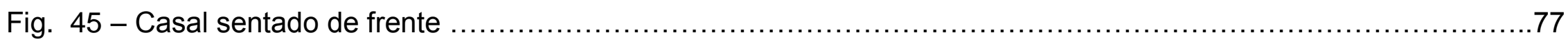

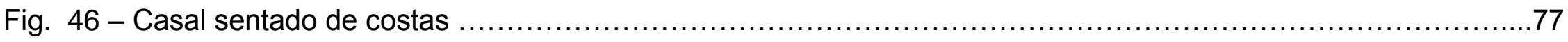

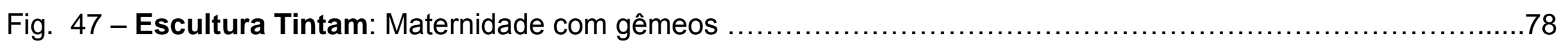

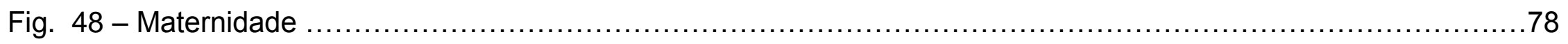

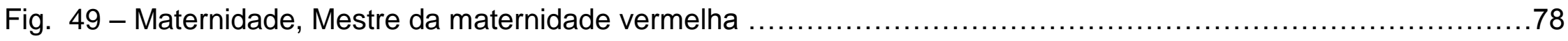

Fig. 50 - Maternidade, (delahe), cabeça, Mestre da maternidade vermelha …......................................................80

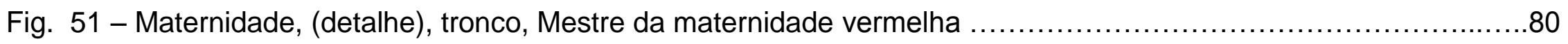

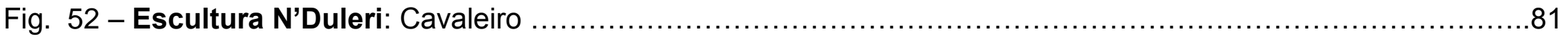

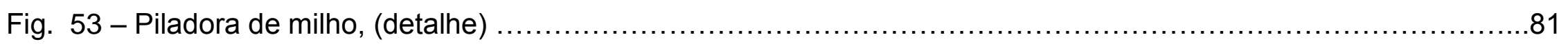

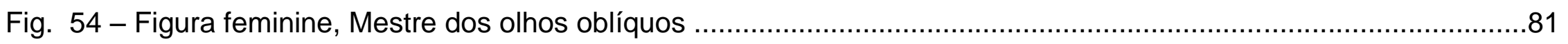

Fig. 55 - Escultura Djenennké: Figura hermafrofita com braços levantados, (detalhe), tronco frontal ...................83

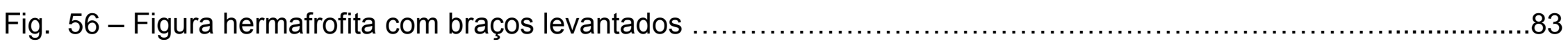

Fig. 57 - Figura hermafrodita com braços levantados, (detalhe), cabeça em perfil ....................................83

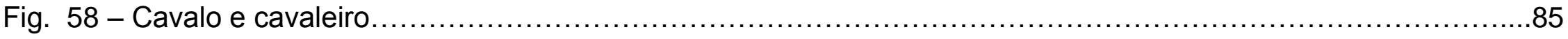




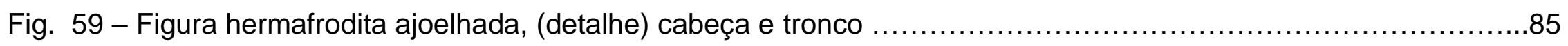

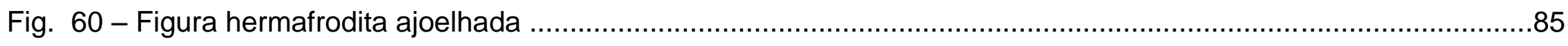

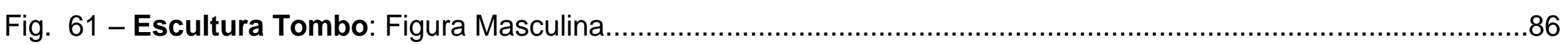

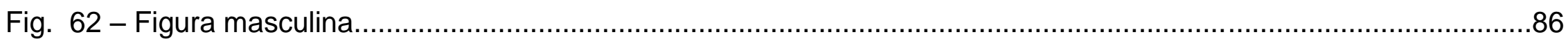

Fig. 63 - Escultura Kambari: Figura sentada com as mãos na boca ............................................................

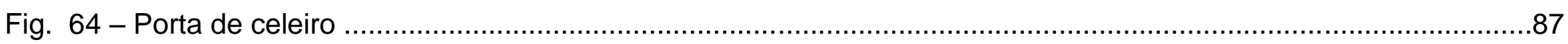

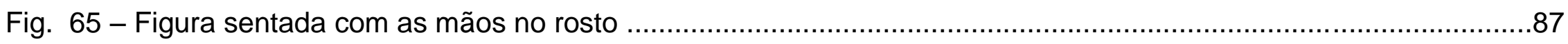

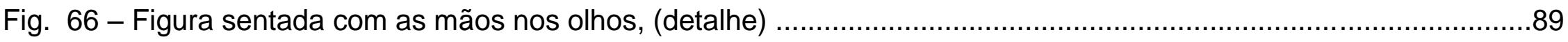

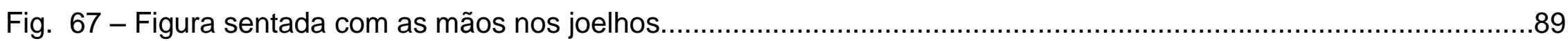

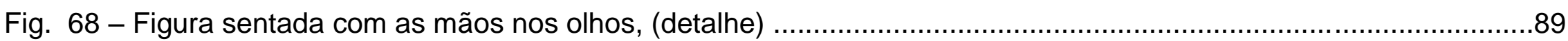


ITINERÁRIO, ESTUDO ESTÉTICO E ESTILÍSTICO DE UMA ESCULTURA DOGON:

"FIGURA HERMAFRODITA" DO MESTRE DE YAYÉ

\section{Sumário}

Introdução

Capítulo 1. - A FIGURA HERMAFRODITA DE NIONGOM, "YAYÉ"

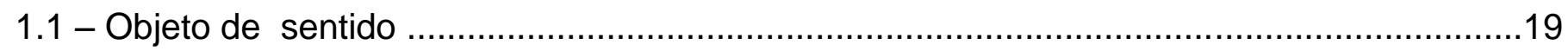

1.2 - Objeto Etnográfico (O Trocadero e as Missões Exploratórias) …………………...............22

1.3 - Objeto Museológico (O Louvre e o Quai Branly) ...........................................................32

Capítulo 2. - O MALI E OS DOGON

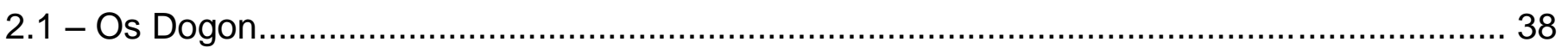

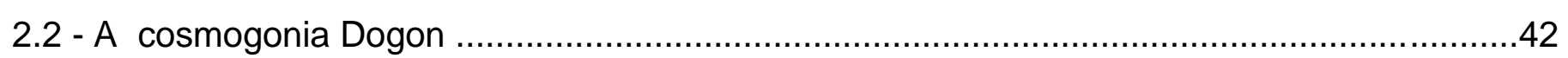

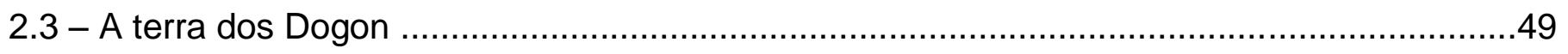

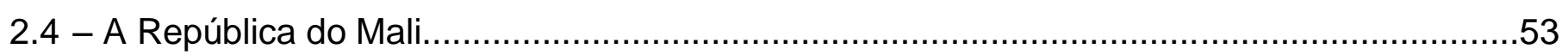


Capítulo 3. - LUGARES DE PRODUÇÃO / LUGARES DE EXPOSIÇÃO

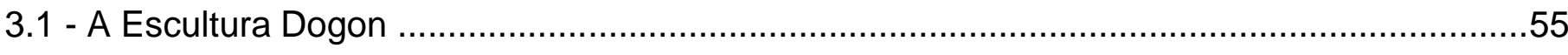

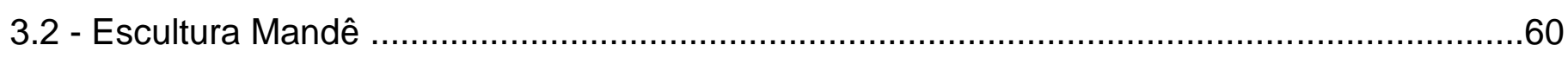

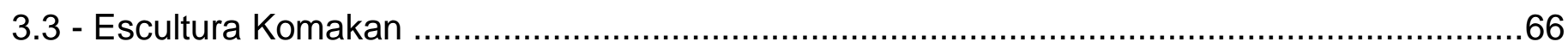

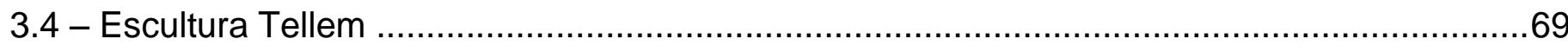

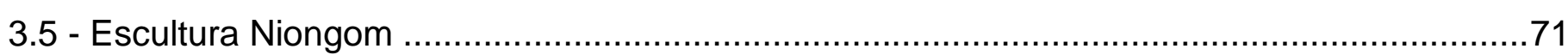

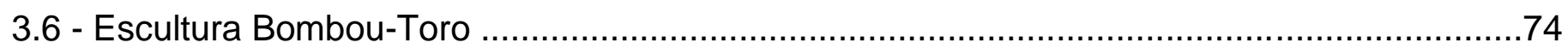

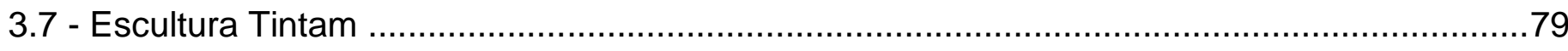

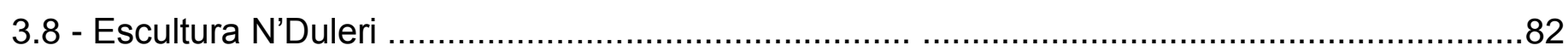

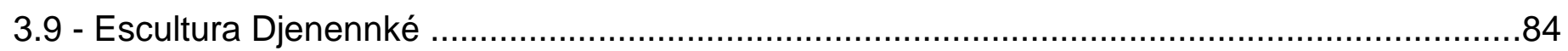

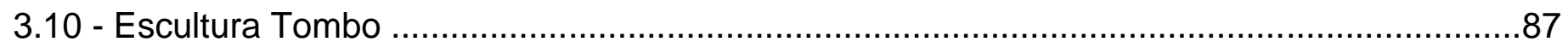

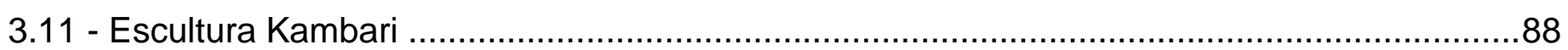

\section{Considerações Finais}

Arte estatuária africana: Que classificação? Para quem? Da descolonização à des-coleção .........89

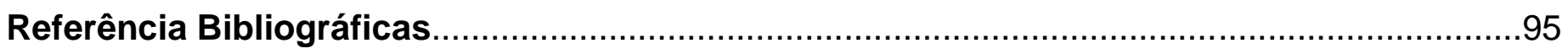


Para Andréa. 
INTRODUÇÃO

A Escultura Dogon tornou-se conhecida no ocidente a partir de 1931 no encontro entre Marcel Griaule e o povo Dogon em Bandiagara durante a missão exploratória francesa Dacar-Djibuti, organizada pelo Museu Etnográfico do Trocadero - na ocasião dirigido por Paul Rivet - com a intenção de coletar objetos e itens para construir as suas coleções.

São esculturas que produzem noções de sentido, ao mesmo tempo em que assumem a sua permanência na atualidade a partir da realidade de seus eventos míticos. Assim, cada peça dessa arte estatuária apresenta uma interação complexa em muitos fatores, incluindo os lugares onde foram produzidas, as influências estilísticas estabelecidas a partir do contato com outros povos, outras culturas e as tradições mantidas, rompidas e reificadas.

A relação entre a França e a sociedade Dogon, sobretudo no século $X X$, foi emblemática por demonstrar fortes laços entre arte, história, etnografia e a prática da "exposição" da Arte Africana em museus. Logo, tomar a arte estatuária Dogon como objeto de estudo implica na necessidade de uma 
contextualização histórica que inscreva na própria noção de estilo a exigência de que se adote uma perspectiva complexa entre objeto e sociedade.

A Figura Hermafrodita do Mestre de Yayé é o foco principal deste estudo. Em torno dela é proposta a criação de uma narrativa que seja capaz de contar, de forma cautelosa, a sua trajetória, desde a sua descoberta, em 1935 na missão Paulme-Lifichtz, até os dias atuais, ressaltando a sua importância na dinâmica da circulação dos objetos e dos lugares conferidos para a exposição da Arte Africana.

Esse trabalho está dividido em três partes: a primeira é focada na Yayé, enquanto "Objeto de Sentido", ou seja, já na abertura aparecem as perguntas que irão defini-la: O que é essa peça? De onde ela veio? E o que a fez tão importante? Qual foi a sua importância para o entendimento da Arte Africana? Ainda na primeira parte vamos defini-la como "Objeto Etnológico", mostrando o que aconteceu quando ela foi levada para Paris e quais foram as transformações que aconteceram com ela e, por fim, como "Objeto Museológico", observaremos seu percurso pelos ambientes de exposição e o quanto isso transformou tanto a concepção de museu quanto a de obra de arte. A segunda parte apresenta os Dogon, sua formação, cosmogonia e localidade geográfica na República do Mali, e a terceira trata dos vários estilos dentro da escultura Dogon, constatando influências múltiplas entre as comunidades.

As principais fontes consultadas para a realização deste estudo foram a bibliografia específica sobre arte Dogon, catálogos de exposições, publicações especializadas e artigos disponibilizados na rede digital. 
1 - "YAYÉ"

1.1 OBJETO DE SENTIDO: FIGURA HERMAFRODITA DO MESTRE DE YAYÉ, NIONGOM, DOGON

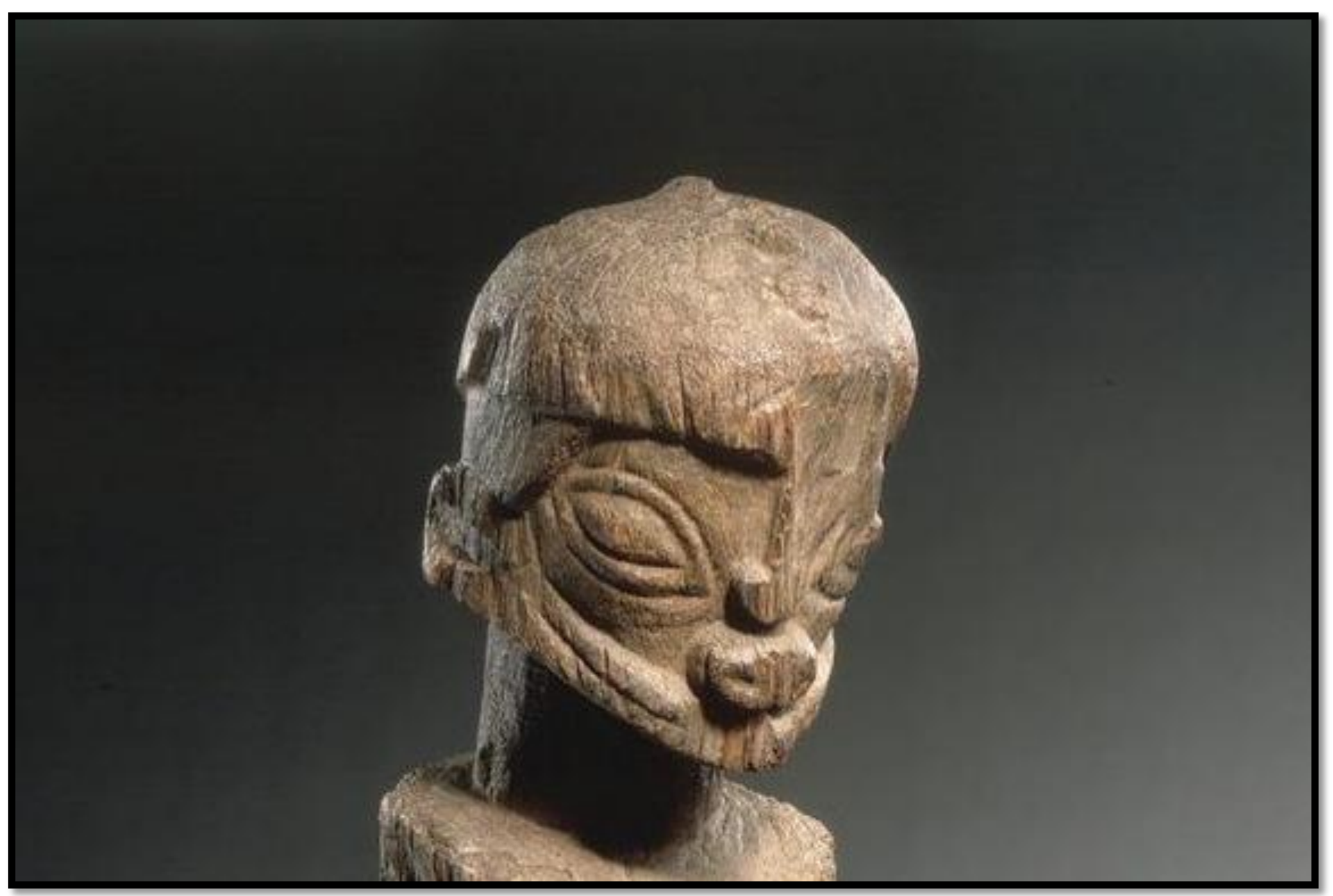


A Figura Hermafrodita do Mestre de Yayé, Niongom, (Dogon, Mali) ou simplesmente, a Yayé, é uma escultura em madeira de raiz (Burkea Africana, da família das cesalpíneas ou hibiscos) de médio porte, com 132 centímetros de altura. Sua datação corresponde aos séculos XVI-XVII segundo testes realizados com Carbono 14. Atualmente, integra o conjunto de obras raras do Museu do Quai Branly ${ }^{1}$ em Paris, na França, catalogada pelo nํㅜ 1935.105.106.

Elegante, esguia, encurvada, cabisbaixa e aparentemente em desequilíbrio, sua forma sugere uma postura dinâmica num movimento vertical que projeta a pélvis para frente, recua o tronco para trás e torna evidente o gesto de apresentar, entre as mãos, as duas genitálias uma ao lado da outra.

Vista de frente (fig.03), nota-se no centro do corpo um umbigo arredondado e ressaltado. Os braços seguem colados à linha do tronco desde os ombros até a pélvis, onde as mãos emolduram as duas genitálias; a feminina construída a partir da escavação de um nó da madeira e a masculina entalhada em posição de repouso sobre o sacro escrotal. Abaixo, estão as pernas curtas separadas por um único vão estreito até a base inclinada sem definição. Também é possível notar escarificações paralelas diagonais no lado esquerdo, abaixo do umbigo e algumas marcas quadriculadas na vertical logo abaixo dos seios.

\footnotetext{
${ }^{1}$ - Atualmente, é considerado um dos museus mais modernos de arte não europeia, "lá onde as culturas dialogam” www.quaibranly.fr
} 


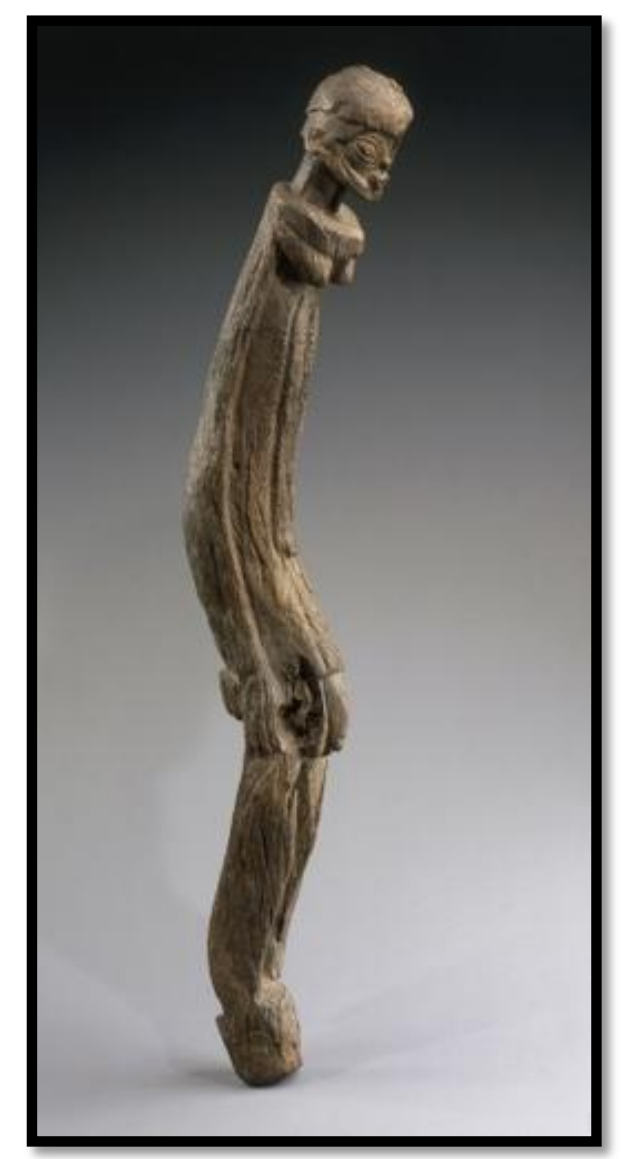

Fig. 02 - "Yayé". Foto: Hughes Dubois (MQB).

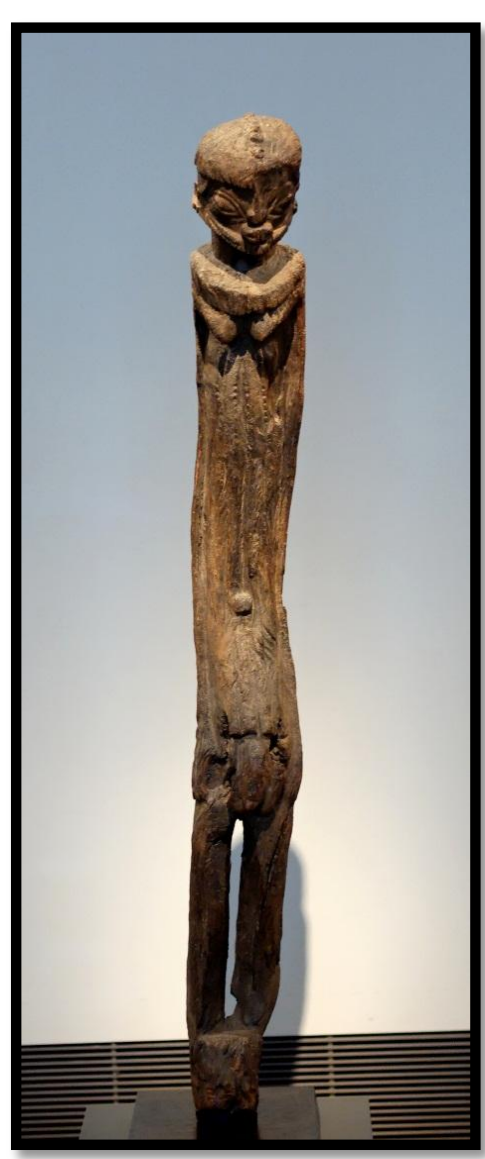

Fig. 03 - "Yayé". Foto: Ji-Elle (Louvre).

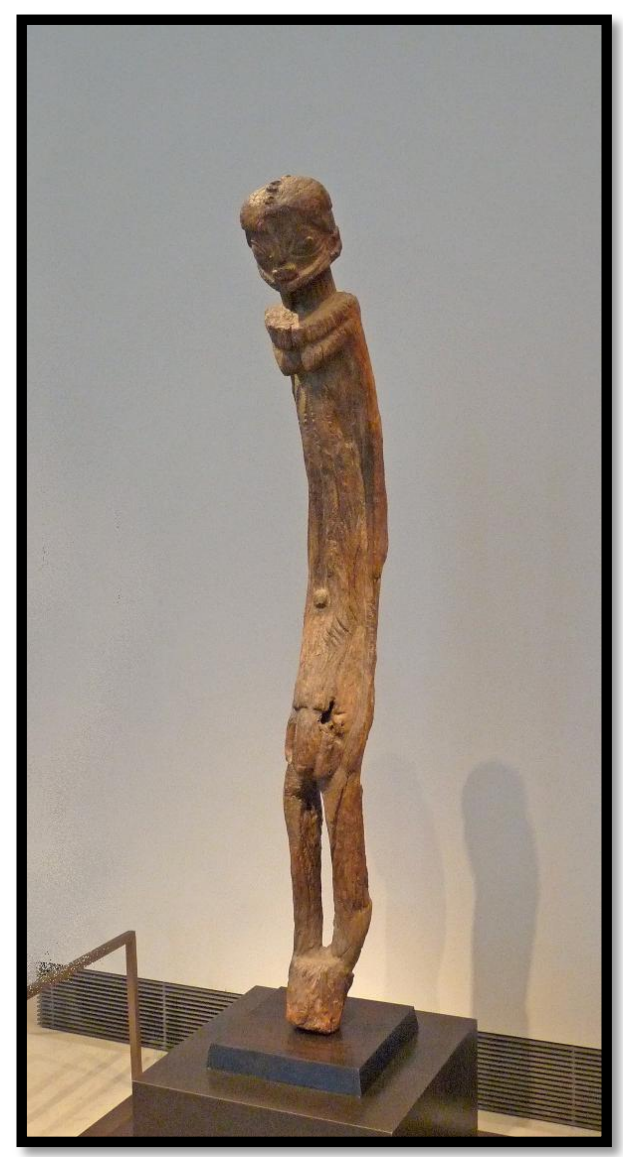

Fig. 04 - "Yayé”. Foto: Ji-Elle (Louvre). 
Vista de perfil, da esquerda para a direita (figura 02), nota-se que o tronco e os membros superiores são maiores que os inferiores; as pernas são curtas e não portam joelhos e nem pés. Os seios são próximos aos ombros, o que torna o colo curto. O rosto está inclinado para frente, é formado por dois grandes olhos amendoados, abertos a partir das falanges do nariz (curto, retilíneo e achatado), que ocupam a maior parte das duas faces até as têmporas. Os lábios são protuberantes e fechados. Os cabelos são aparados em dois planos: o plano superior sugere uma espécie de capacete com uma sequência de pequenos relevos centralizados e alinhados da nuca à testa, formando ao final uma franja curta; o plano inferior encobre a nuca e as têmporas e contorna as orelhas. A barba também é aparada em dois planos e o pescoço é ligeiramente alongado. Por todo o corpo há uma textura construída naturalmente pelos veios verticais da madeira de raiz totalmente integrada à refinada intervenção do escultor em preservar na forma original o que já estava inscrito como escultura. Observada da direita para a esquerda, já não dá mais para se ver a genitália feminina. Nota-se porém que a perna esquerda é mais grossa e curvada que a direita, assim como o braço esquerdo o é em relação ao direito.

A escultura de um mestre Dogon participa de um conjunto de relações que faria desta obra um símbolo seja para entendermos seu universo de sentido, seja para percorrermos uma itinerância de objetos que criaram narrativas no interior da história da arte europeia do século XX. Neste percurso, ela agregou em si um sentido duplo: objeto estético e objeto histórico.

A história dessa escultura reconta, ainda, a história de tantas outras esculturas africanas recolhidas pelas missões exploratórias colonialistas europeias em África assim como a história da etnologia francesa, da museologia e das práticas de expor objetos-alteridade que se opõem, frequentemente, os objetos-arte dos mestres europeus. 


\section{2 - O TROCADERO E AS MISSÕES EXPLORATÓRIAS}

No período entre guerras, a arte na Europa encontrava-se em crise com o seu próprio lugar na modernidade sem ter ainda encontrado linguagem própria de expressão que a separasse do século XIX (RUBIN, 2006). A França lançava-se em busca de novos desafios a fim de legitimar sua experiência colonial no processo de agressão ao continente africano (BRUMANA, 2011). Este foi o clima que permitiu uma série de missões científicas, entre elas, a Missão Dacar-Djibuti, que levou a campo uma equipe multidisciplinar e marcou simbolicamente a transformação da etnologia francesa, até então, de gabinete.

A missão colonial, Etnográfica e Linguística Dacar-Djibuti (1931-1933) foi organizada pelo Instituto de Etnologia da Universidade de Paris e o Museu Nacional de História Natural com a intenção de recolher objetos para as coleções etnográficas francesas. Dirigida por Marcel Griaule, essa missão teve uma vultuosa produção subvencionada pelo governo francês e diversas manifestações de patrocínios de voluntários, inclusive uma luta de boxe com o campeão mundial, o norte americano Al Brown (LELOUP, 2011). 


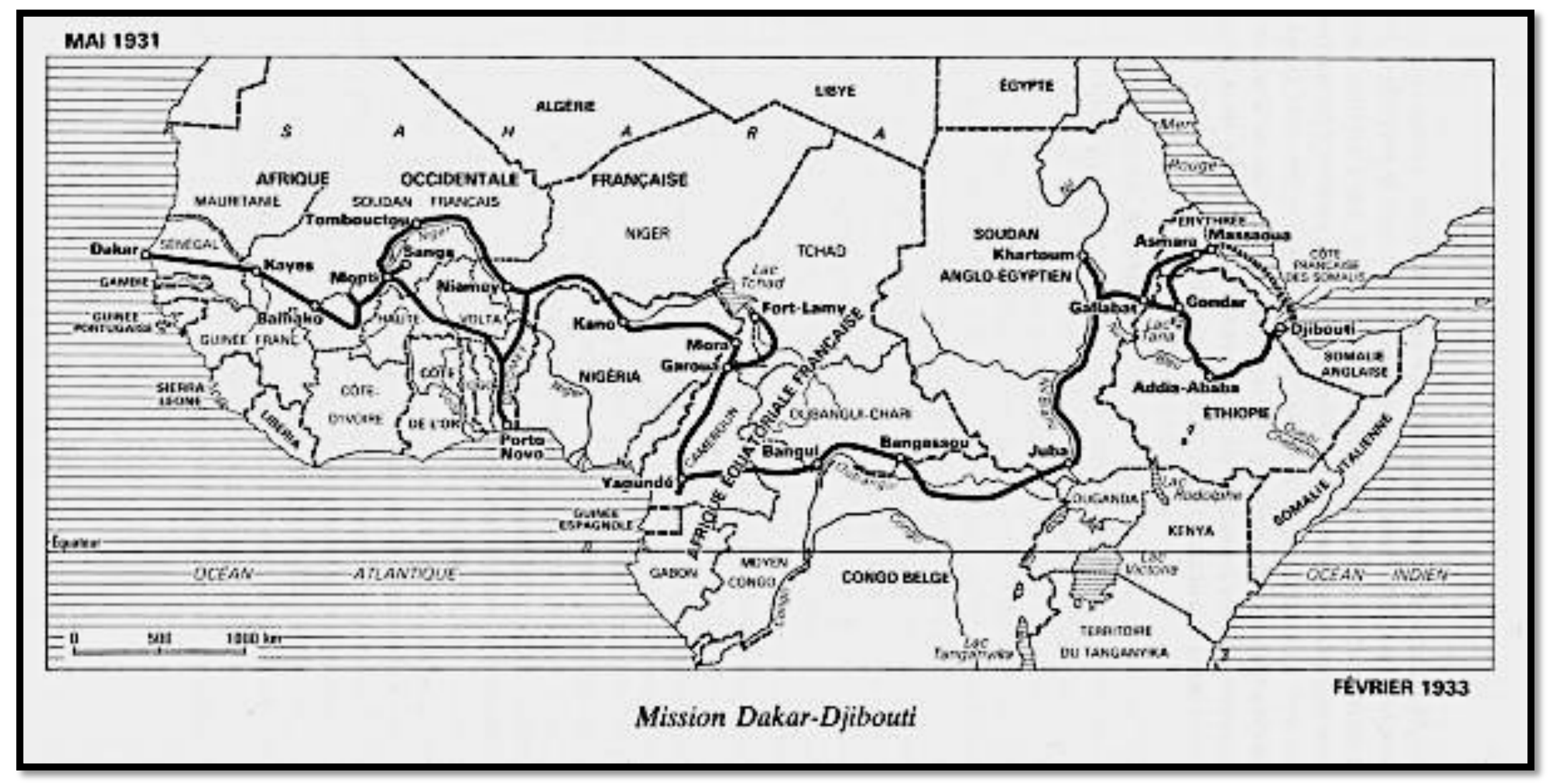

Figura 05 - Mapa com o percurso da Missão Dacar-Djibouti. Fonte: http://inton.over-blog.com/article-696638.html 


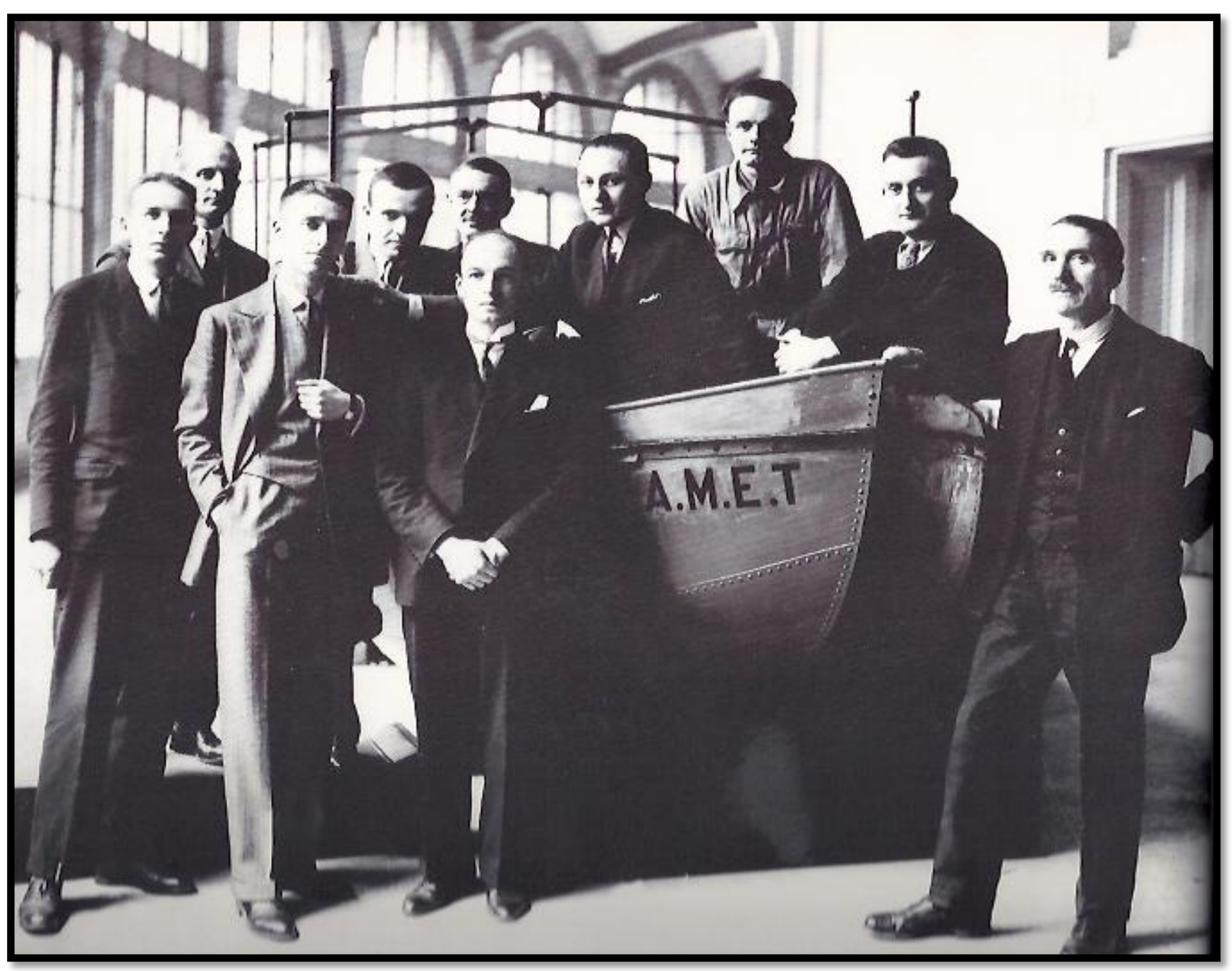

Figura 06 - A equipe da Missão Dacar-Djibuti. Da esquerda para a direita: André Shaeffner, desconhecido, Georges Henri-Rivière, Michel Leiris, Michel Oukhtomsky, Marcel Griaule, Éric Lutten, Jean Mouffle, Gaston-Louis Roux e Marcel Larget Fonte: Fototeca do Musée de l'Homme, Paris. 
Integrada por intelectuais surrealistas e colaboradores da revista Documents: Archéologie, Beaux Arts, Ethnografie et Varieté, (dirigira por Carl Einstein), fascinados pelas formas e o anti-realismo da "arte negra" (LELOUP, 2011), a missão Dacar-Djibuti atravessou o continente africano, do Oceano Atlântico ao Mar Vermelho durante vinte e um meses num percurso de mais de vinte mil quilômetros, alcançando um grande sucesso e um forte impacto sobre a escola etnológica francesa.

Os franceses viajaram, entre outras motivações, em busca da coleta de objetos e informações que deveriam complementar e preencher as lacunas de estudos e, sobretudo, das coleções africanas do Museu do Trocadero ${ }^{2}$ fundado em 1878. Os objetos deveriam permitir o enriquecimento de coleções da produção material de sociedades distanciadas, que já eram conhecidas do público por meio das exposições coloniais em Paris, Londres, Berlim, Lisboa etc (BRUMANA, 2011).

A escolha de material não respondia a critérios bem definidos, devendo, sobretudo, servir de testemunho de determinada cultural material ainda não suficientemente conhecida das sociedades do norte. O debate sobre seus valores estéticos ou expressivos vieram posteriormente. Foram coletados 3.500 objetos, 600 fotografias, 15.000 fichas de observações, além de filmes, 200 gravações se áudio, uma coleção de pinturas etíope e todos os tipos de amostras (DE L'ESTOILE, 2010).

2 - Museu Etnográfico do Trocadero foi fechado em 1935, seu prédio demolido, sendo seu o acervo transferido para o Museu de l'Homme. 
A revista Minotaure, do grupo de artistas surrealistas, publicou em 1931 um número inteiramente dedicado à expedição com textos de alguns de seus integrantes. Em 2009, a missão foi tema de uma excelente e definitiva exposição, "A Missão etnográfica e linguística Dacar-Djibuti (1931-1933) e o fantasma da África”, em Valência, na Espanha.

Após a missão Dacar-Djibuti outras expedições foram realizadas: Saara-Sudão (1935), SaaraCamarões (1936-1937) e Níger-Lago Iro (1938-1939), no decorrer das quais foram criadas novas escolas e teorias para o estudo das culturas não ocidentais.

"De 1935 a 1939, Marcel Griaule organizou expedições em grupo ao Sudão francês (Mali), a Camarões e ao Chade, nas quais a coleta destinada a museus desempenhava um papel menor. Em visitas anuais ou bianuais à África Ocidental, concentrando-se cada vez mais nos Dogon, ele desenvolveu um "método" etnográfico no qual a coleta de artefatos era parte da documentação intensiva sobre uma área da cultura unificada, uma região cujo centro ficava na curva do Níger, particularmente os Bambara e os Dogon - com quem ele permaneceu por cerca de três anos ao longo de mais de dez expedições" (CLIFFORD, 2011).

A Figura Hermafrodita do Mestre de Yayé foi produto indireto da missão Griaule, pois ela só foi encontrada posteriormente por Denise Paulme e Debora Lifchitz.

Denise Paulme ${ }^{3}$ iniciou seus estudos em Etnologia com Marcel Mauss ${ }^{4}$, num momento em que, na França, ainda não havia etnólogos profissionais e o trabalho etnológico era feito por diretores,

3 - Etnóloga e antropóloga africanista francesa (1909-1998). Junto com Debora Lifchitz encontraram e trouxeram a Yayé para Paris.

4 - Sociólogo e antropólogo francês (Épinal 1872 - Paris 1950), fundou o Instituto de Etnologia da Universidade de Paris (1925) e lecionou no Collège de France (1931-1939). Os trabalhos mais importantes do autor aparecem no livro Sociologie et Antropologie (1960). 
viajantes ou médicos coloniais. Sua primeira influência etnológica teria sido o seu próprio pai, JeanCharles Paulme, que, mesmo sem ser um colecionador profissional, colaborou e participou da organização da Exposição Colonial; doou 272 objetos de arte ao Museu de l'Homme, trabalhou na África Ocidental e dividiu desde cedo com sua filha o interesse pelos objetos de Arte Africana. Em 1932, já licenciada em Direito e diplomada pelo Instituto de Etnologia, Denise Paulme entrou para 0 Departamento da África Negra do Museu de Trocadero, com a tarefa de trazer para os métodos de colonização uma contribuição etnográfica que descrevesse as crenças, técnicas e tradições dos povos africanos e colaborasse humanamente para a compreensão da arte do outro a partir de uma exploração mais racional dos recursos naturais. Submeteu-se a trabalhar por um salário simbólico para ajudar na reconstrução do Museu do Trocadero, (famoso pelo mofo, a poeira, a penumbra, a desorganização das coleções e a falta de aquecimento), até que em 1934 surgiu a oportunidade de concorrer a uma bolsa da Fundação Rockefeller no valor de 50.000 francos para a preparação de sua tese de doutorado. Foi contemplada com a bolsa e a possibilidade de ir a campo para fazer a sua pesquisa tornou-se realidade.

Em parceria com Debora Lifchitz ${ }^{5}$, formou uma nova missão etnográfica independente, denominada Missão Paulme-Lifchitz. Juntas, acompanharam a Missão Saara-Sudão em Bandiagara, mas permaneceram por mais tempo para iniciarem suas pesquisas individuais. Chegaram ao Pays

\footnotetext{
${ }^{5}$ Etnolinguísta nascida na Russia em 1907, trabalhou no Museu de l'Homme em Paris e participou da Missão Dacar-Djibuti. Recebeu cidadania francesa em 1937. Em fevereiro de 1942, foi presa e levada para campo de concentração francês e de lá para Auschwitz, onde foi assassinada na câmara de gás. Durante seus estudos e trabalho no Musée de l'Homme, Deborah Lifchitz estudou e colaborou com os maiores antropólogos e africanistas daquele momento,

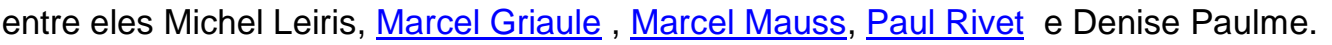


Dogon durante uma longa viagem, de fevereiro a outubro de 1935, com a intenção de superarem o que tinham combinado com Marcel Griaule: a princípio a função das pesquisadoras era revelar uma orientação estética através da coleta de objetos em visitas etnográficas oportunas para preencher as coleções do Museu de l'Homme, contribuindo assim com o projeto de sua remodelação e em seguida elaborar um panorama da escultura africana (DE L'ESTOILE, 2010).

No decorrer da missão Saara-Sudão foram recolhidas 170 peças esculpidas em madeira onde mais da metade eram fechaduras antigas, com estilo e características próprias, mostrando a evolução de um verdadeiro estilo, e que, mesmo para um especialista, seriam uma revelação para a escultura Dogon. Também foram recolhidas uma dezena de estatuetas de braços levantados, quase todas em muito bom estado. Mas, o grande acontecimento ocorreu por acaso quando as pesquisadoras Denise Paulme e Debora Lifchitz, ao visitarem o vilarejo de Yayé, observaram que havia uma escultura em madeira enterrada até o pescoço, na qual amarravam-se animais. Ao questionarem qual o sentido daquela escultura estar enterrada, obtiveram a seguinte resposta: "Ela está esperando pelo retorno de seus verdadeiros donos, aqueles que a fizeram e enterraram antes de chegarmos aqui". (PAULME, 1992, p.86). 
No documentário "Dogon, chronique d'une passion" de Guy Seligmann, 1996, Denise Paulme comentou que a conquista da Yayé foi uma negociação complicada; a princípio, os Dogon do vilarejo não queriam sequer comentar os motivos da escultura estar enterrada ali. Talvez por respeito ou temendo alguma desgraça, eles não queriam que a mesma fosse desenterrada e somente depois de alguns acertos e muito tempo de conversa elas, finalmente, conseguiram convencê-los a vender a estátua, sem que ninguém soubesse. Feito o acordo, elas tiveram que desenterrar a escultura com as próprias mãos, assumindo a responsabilidade pelo ato e pelo deslocamento. Vale salientar que ambos os lados sabiam dos riscos dessa situação; se por um lado a escavação da escultura revelaria o que a parte enterrada escondia e inevitavelmente contribuiria para aumentar o seu valor enquanto objeto de arte etnográfica, por outro lado a escultura extraída do seu local de origem deixaria de ser uma peça de ritual e passaria a ser um objeto etnográfico e depois objeto de arte, uma peça de coleção de museu. Mas, o que estava para ser revelado era uma obra da mais refinada intenção artística: a Figura Hermafrodita do Mestre de Yayé, Niongom, Dogon: obra prima de um autor desconhecido, estilo singular, datação a ser estimada pelo Carbono 14, localidade de produção incerta e misteriosamente abandonada naquela região (SELIGMANN, 2007). 


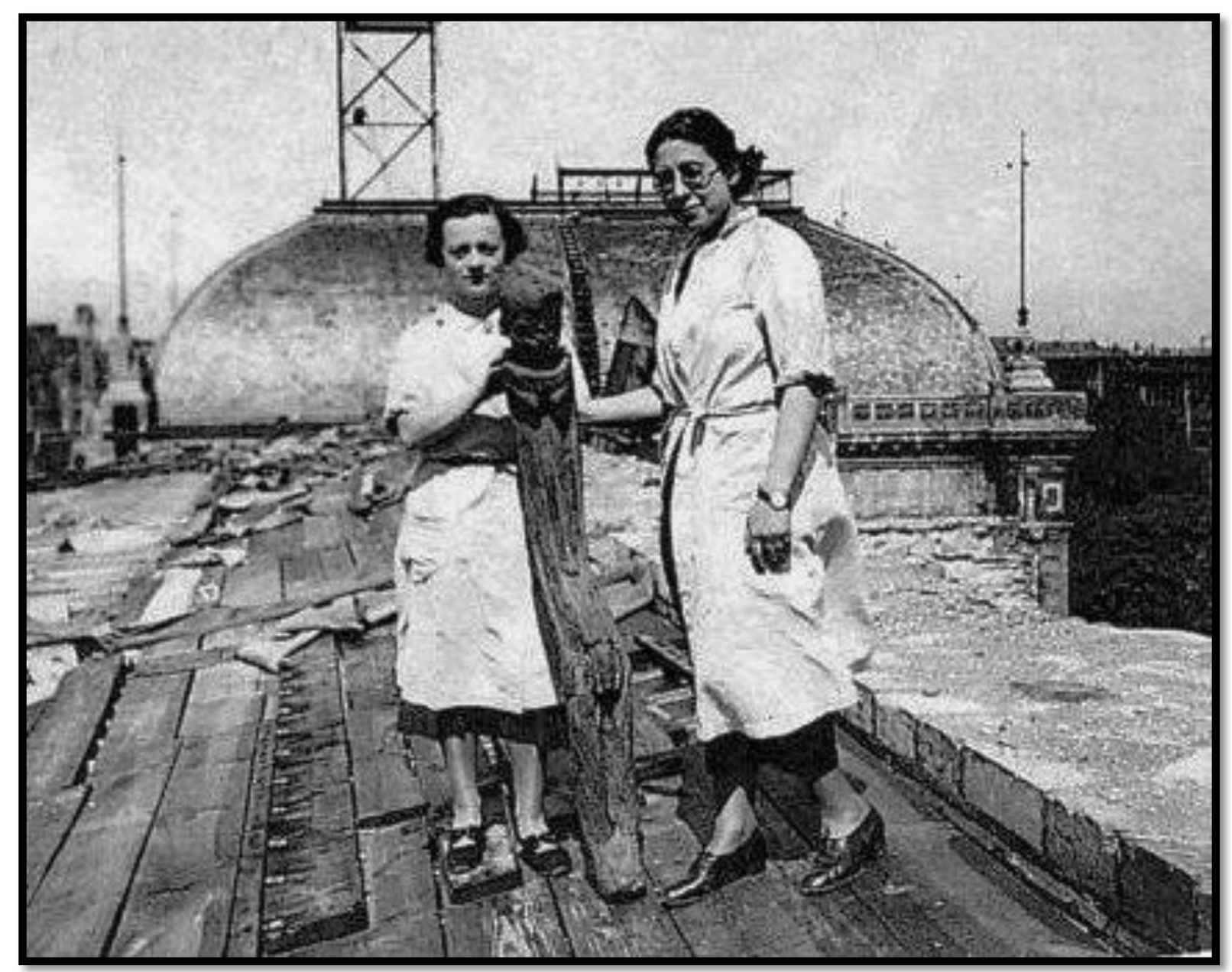

"Temos uma estátua de um metro e trinta centímetros, de estilo até agora desconhecido e anterior sem dúvidas, à chegada dos Dogon - corpo, hermafrodita, a cabeça emerge uma emoção profunda, o que faz dessa estátua uma obra prima, no verdadeiro sentido da palavra" Charles Ratton (PAULME, 1935).

Figura 07 - Denise Paulme e Debora Lifchitz com a Yayé nos terraços do Museu de Etnografia do Trocadero. Paris, 1935. 


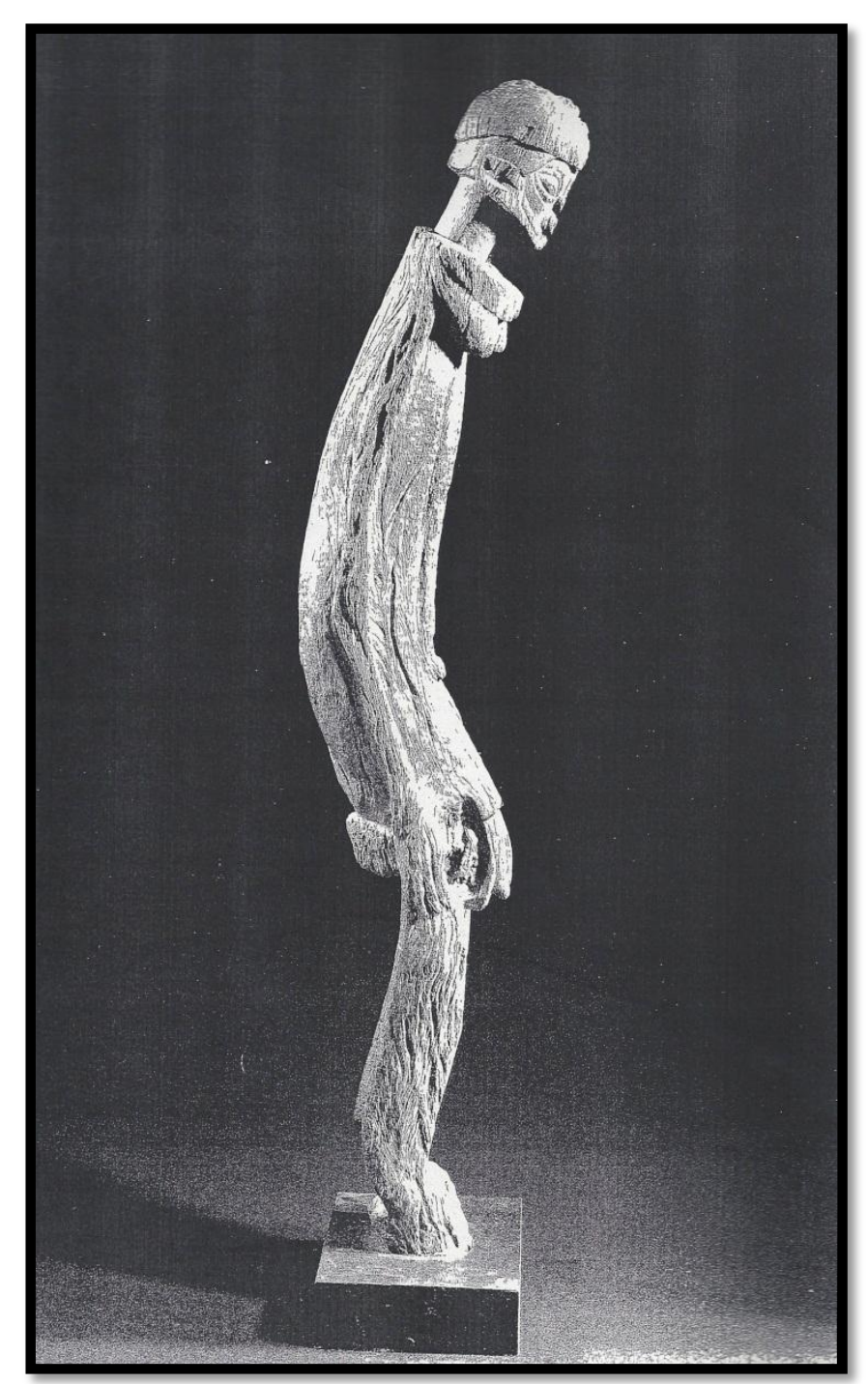

Figura 08 - Fotografia de Man Ray, 1935.

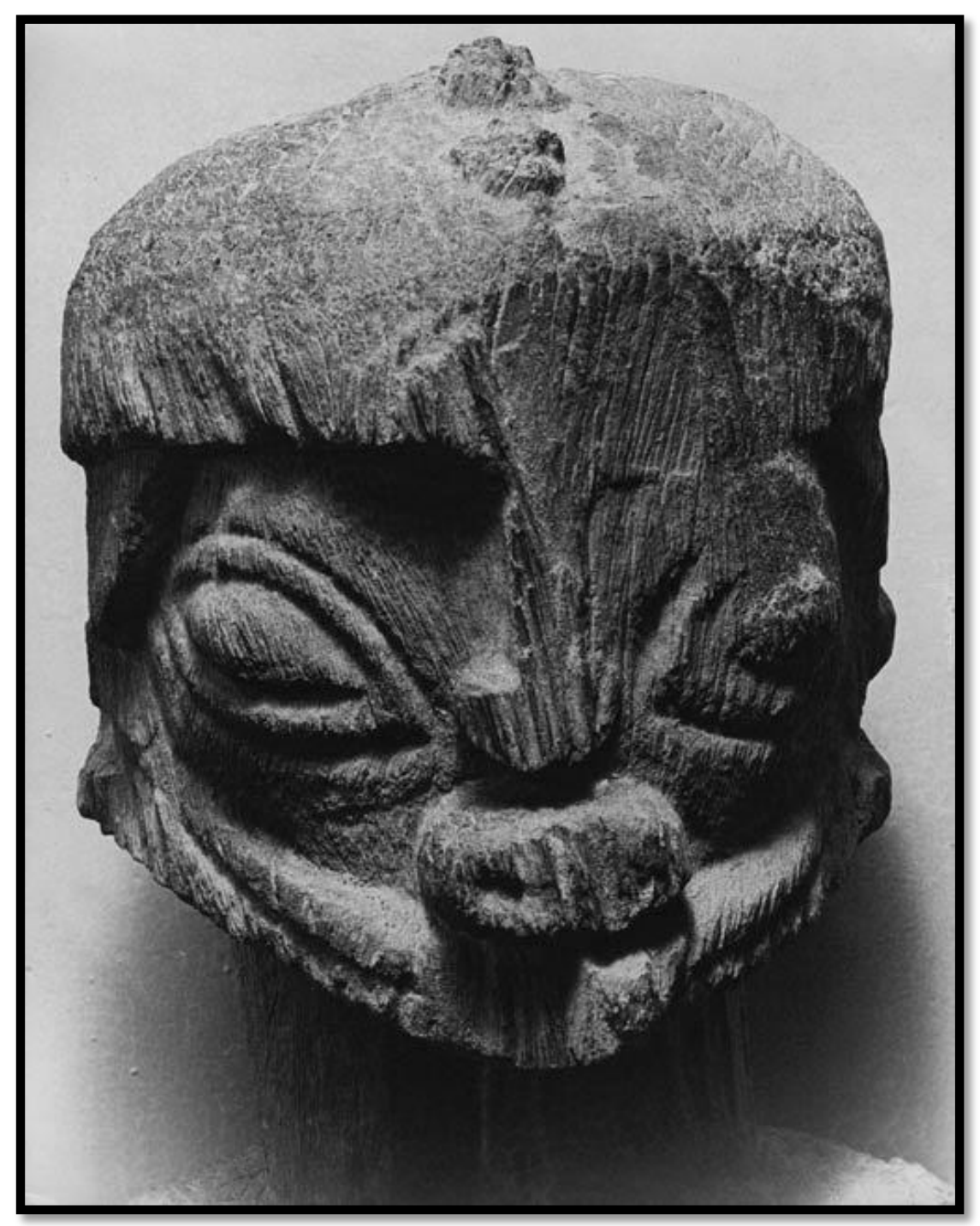

Figura 09 - Fotografia de Erwin Blumenfeld, 1936. 
A fotografia apresentada na figura 08, foi feita pelo fotógrafo e pintor surrealista Man Ray em 1935, no mesmo ano de sua descoberta. Nela, a Yayé aparece de corpo inteiro na posição vertical sob uma iluminação dramática que valoriza os limites da forma contrapondo-a ao fundo escuro. Nessa imagem já é possível perceber que o grande desafio do escultor foi integrar o formato original do tronco à sua própria noção de suporte tridimensional, para veicular uma narrativa que contasse a história dos seus antecessores, fornecendo pistas por meio do entalhe da composição da figura presentificada, por onde se pudesse descrever estilisticamente os aspectos visuais desse ancestral para o reconhecimento das futuras gerações e pela continuidade da dinâmica inscrita nas tradições de seu povo.

A fotografia do retrato da Yayé tem a autoria do fotógrafo alemão Erwin Blumenfeld, (1897-1969), reconhecido por suas fotografias artísticas com nus femininos, fotomontagens antinazistas e por ter sido o fotógrafo que mais tomou as capas da revista Vogue, umas das principais publicações da moda europeia, durante as décadas de 1940 e 1950. É uma imagem rara, um dos poucos retratos em close da Yayé, se não o único, feito década de 1930, logo após a sua descoberta. Nela, nota-se que o lado esquerdo do rosto foi deteriorado por uma falha subtrativa que atingiu parte da testa, o olho, o nariz e a boca. Essa falha apresenta uma imagem incompleta em sua totalidade, assim como uma vênus sem os braços ou uma Vitória sem a cabeça e tantas outras peças gregas que tiveram o nariz ou a genitália quebrada. No caso da Yayé essa deformação pode ter ocorrido por consequência da ação do tempo ou por um acidente qualquer, já que a peça ficou por muito tempo exposta às intempéries naturais e, até ser recolhida, certamente a sua função inicial foi subvertida; passando de objeto de culto religioso à uma simples estaca de amarrar animais, até ser desenterrada e migrar para a condição de destaque entre as obras primas de um museu de arte e voltar para a reserva técnica de um outro museu que privilegia o 
diálogo entre as culturas, mas que escolhe a hora e o momento certo para apresentar os seus tesouros de guerra.

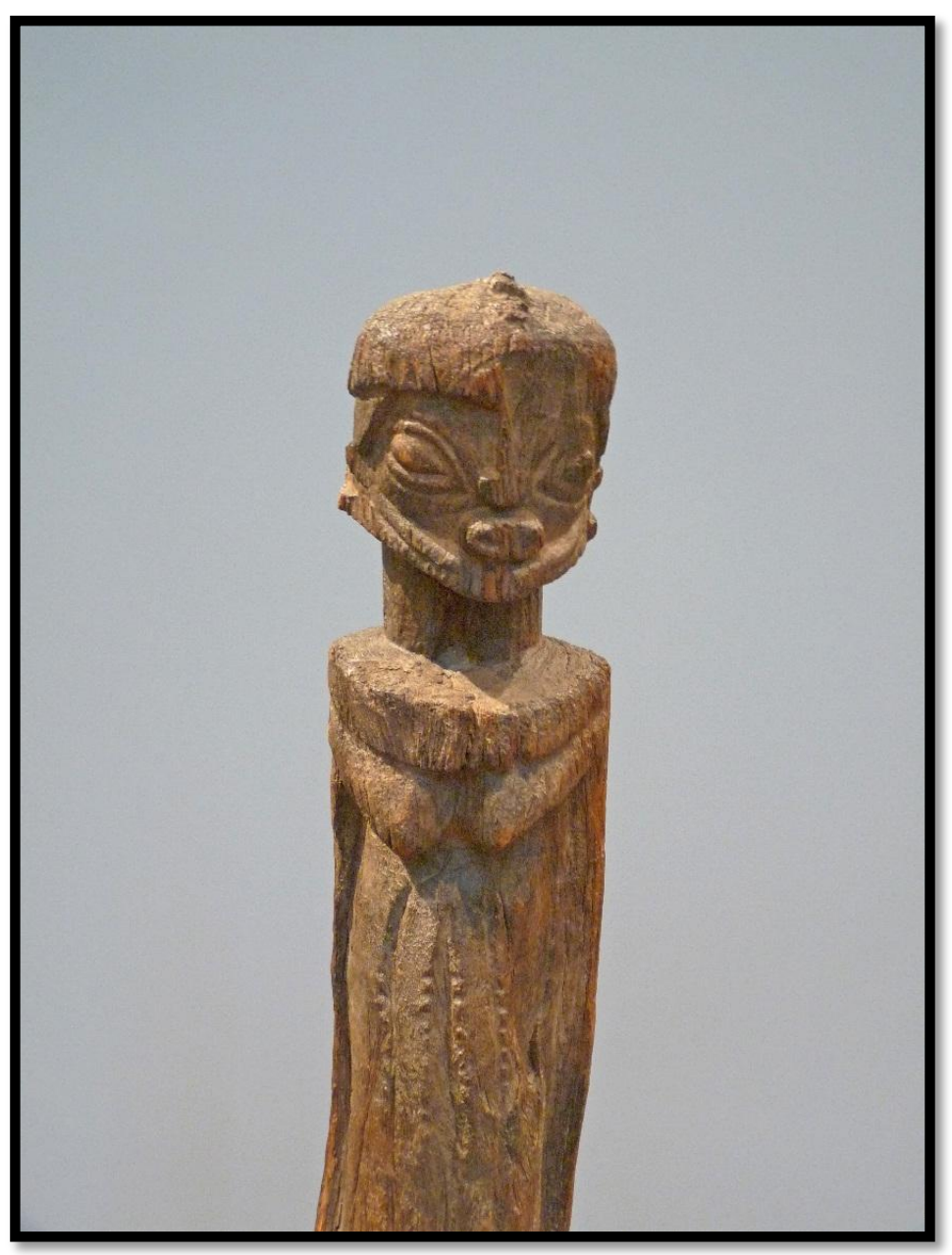

"Entre as esculturas mais espetaculares, encontramos as hermafroditas misteriosas. Para entender essas estátuas, deve-se esclarecer o conceito de perfeição Dogon decorrente da re-união do que foi separado. Para os jovens iniciados, essas estátuas explicam a necessidade do dualismo existente na natureza, a diferenciação social entre homens e mulheres, a distinção entre os sexos - onde um deles teve que transgredir, a fim de alcançar a perfeição e a continuidade da vida. Temos aqui a ilustração de um conceito típico Dogon: o masculino contém o feminino, que também contém o masculino" (LELOUP, 2010).

Figura 10 - Yayé no Louvre. Foto: Ji-Elle 


\section{3 - OBJETO MUSEOLÓGICO (O Louvre e o Quai Branly)}

A Yayé chegou ao Trocadero em 1935 no mesmo ano de seu fechamento e dois anos antes da sua demolição, foi transferida para o Museu de l'Homme, dirigido por Paul Rivet cuja intenção fora criar um museu novo, ancorado em pesquisa e ensino. Naquele momento de transição, era reconhecida como um objeto etnográfico e não como obra de arte. No ano 2000, Yayé foi escolhida para integrar o conjunto de esculturas do Pavillon des Sessions do Museu do Louvre, classificada como uma das cem obras primas das "artes dos outros", as quais podemos definir como representações coletivas, que não são produzidas por um indivíduo específico, mas que advém de uma prática amplamente compartilhada.

Essa requalificação do objeto etnográfico em obra de arte, assim como a transformação dos museus voltados às disciplinas antropológicas em museus de arte, não teve uma passagem tranquila e o debate ainda está em aberto embora esse novo conceito de museu tenha se espalhado pelo mundo todo.

A função de um museu etnográfico é promover uma visão do mundo. O museu é um microcosmo que ordena o mundo a partir de um ponto de vista, assim, o museu dos "outros" oferece uma viagem alternativa por mundos distantes, onde é possível classificar os objetos em função do seu valor do ponto de vista histórico e do conhecimento. 
Artes Primeiras são as produções artísticas tradicionais de culturas não-ocidentais. Entenda-se por não-ocidentais toda a produção cultural produzida fora do continente europeu a partir da expansão colonizadora.

"A noção de Arte Primeira não é um conceito a ser encarado por uma análise rigorosa: é apenas mais uma noção cuja a principal qualidade é a de ser capaz de funcionar em diversas concepções. É a partir da sua forma de uso que vamos abordá-la. Um índice é que ela substitui cada vez mais as "artes primitivas" no mundo da arte. Os catálogos de arte e os próprios livros de História da Arte a partir de 1995 já adotam essa nomenclatura ao invés de Arte Primitiva ou arte Tribal" (DE L'ESTOILE, 2010).

As denominações arte primitiva, arte tribal, arte negra, arte selvagem, arte ágrafa, arte troglodita, arte da África negra etc., são invenções sugeridas pela crítica ocidental, eurocêntrica, na intenção de definir o sistema de produção artística das sociedades não europeias (ditas “outras") em suas diversas categorias. Poderíamos então dizer que tais denominações acontecem quando não se sabe denominar o outro ou as artes dos outros. Mesmo quando esses sistemas não estejam limitados apenas às artes visuais, pois pertencem a um ideal estético que envolve mais que uma categoria artística para constituir a totalidade da sua expressão.

"O olhar eurocêntrico, por vezes, acorrenta a produção de arte no continente africano à ideia de produção anônima, ligada unicamente à religiosidade, em um sistema no qual a crítica não existe e em que toda a obra segue padrões iconográficos preestabelecidos pela tradição. De fato, a produção imagética de diferentes culturas africanas está intimamente vinculada ao sagrado, até mesmo porque em muitas dessas culturas o sagrado não se desvincula de nenhum dos atos cotidianos vivenciados na comunidade, assim como perpassa cada elemento existente na natureza e se faz igualmente presente em toda criação 
humana [...] O sagrado, somado ao artista, à comunidade, ao consumo e à influência imagética de outras culturas, estrutura, acrescenta e modifica a forma do objeto artístico e o modo como ele é pensado e fruído" (LOPES, 2011, p.396).

Segundo o antropólogo e filósofo argentino Néstor García Canclini - para quem as Artes Primeiras é uma forma rebuscada para não dizer "artes primitivas":

“...o Museu do Quai Branly, (lá onde as culturas dialogam), em Paris, é uma instituição que propõe renovar os critérios de seleção, exibição e valorização de objetos de culturas não europeias, tentando renovar as relações entre arquitetura, artefatos culturais e arte e procura restabelecer a França nos intercâmbios globais. Além disso, antes e depois da sua abertura, em 2006, o Quai Branly gerou estudos e debates entre antropólogos, museógrafos, artistas, arquitetos e políticos da cultura de muitos países, como talvez não tenha acontecido a propósito em nenhum outro museu, bienal, feira ou evento artístico-cultural” (CANCLINI, 2012, p.101).

O museu do Quai Branly nasceu como um projeto do presidente Jacques Chirac para unir as coleções do Trocadero e recolocar a França num lugar de destaque no cenário da arte mundial. O edifício projetado pelo arquiteto Jean Nouvel e o paisagismo concebido por Gilles Clément, foi inaugurado em junho de 2006. Em sua inauguração, a então ministra da cultura do Mali, AminataTraoré (apud LAGROU ${ }^{6}$, p.219), salientou:

“...o Musée Quai Branly é "uma das expressões perfeitas dessas contradições, incoerências e paradoxos da França com relação à Africa. Na hora em que este abre suas portas ao público, continuo me perguntando até onde irão os poderosos desse mundo na arrogância e na violação do nosso imaginário. Somos convidados hoje a celebrar com a antiga potência colonial uma obra arquitetônica sem dúvida bela, assim como nossa própria perda com a conivência de atores políticos

\footnotetext{
${ }^{6}$ Horizontes Antropológicos, Porto Alegre, ano 14, n. 29, p. 217-230, jan./jun. 2008). Disponível em: http://www.scielo.br/pdf/ha/v14n29/a09v14n29.pdf
} 
e institucionais africanos, que estimam que nossos bens culturais estão melhor nos belos edifícios do Norte do que sob nossos próprios cuidados.

Contesto o fato que a ideia de criar um museu deste porte possa nascer não de um exame rigoroso, crítico e partilhado das relações entre a Europa e a África, a Ásia, a América e a Oceania, de onde as peças são originárias, mas da amizade de um chefe de Estado com um colecionador de obras de artes. As 300.000 peças que o Musée Quai Branly guarda constituem um verdadeiro "tesouro de guerra"; por causa do modo de aquisição de alguns deles e do tráfico de influência ao qual estes, às vezes, se prestam entre a França e os países de onde provêm. (Traoré, 2006) ${ }^{7}$.

O trabalho de orientação ao público, impresso nos folhetos de comunicação do Museu do Quai Branly, complementam a visitação acolhendo a história dos continentes. O Guia do leitor apresenta uma biblioteca destinada à pesquisa etnológica, antropológica e da história da arte das civilizações da África, Ásia, Oceania e das Américas, voltada para o público universitário, pesquisadores, profissionais da cultura e do patrimônio, mas também para o grande público, não especialista, curioso e que deseja informar-se sobre as coleções e atualidades do museu. Tem como missão acompanhar as pesquisas universitárias, informar sobre as coleções, conservar as coleções patrimoniais e ser um lugar para mediação da cultura. Entre os setores disponíveis aos visitantes estão os quatro espaços de consultas: a biblioteca de estudo e pesquisa, a sala de consulta dos arquivos e da documentação das coleções, a seção de obras raras e a sala de leitura que leva o nome do idealizador do museu, o colecionador Jacques Kerchache. Quatro catálogos on-line e um portal documentário. As coleções somam 250.000 documentos impressos, 10.000 documentos sonoros e áudio visuais, 8.000 revistas eletrônicas, mais de 40.000 livros digitais (e-book), 700.000 peças iconográficas, fotografias e artes gráficas e 65.000 documentos de arquivo ${ }^{8}$.

\footnotetext{
7 - Disponível em: http://www.scielo.br/scielo.php?pid=S0104-71832008000100009\&script=sci_arttext
}

8 - Disponível em: www.quaibranly.fr 
O mapa do museu está impresso em diversos idiomas e apresenta de maneira fácil e didática todas as suas dependências. O guia prático para deficientes auditivos convida para a prática da língua francesa dos sinais, orientando o visitante sobre todas possibilidades de visitação. A entrada é gratuita para o deficiente e um acompanhante, mediante a apresentação de uma justificativa que comprove a deficiência. $O$ guia prático para deficientes visuais é impresso em braile e apresenta informações e conselhos para o visitante: como chegar, como se orientar no museu, as atividades culturais e as possibilidades de uma visita autônoma. Há uma variedade de guias para os visitantes: um pequeno guia para crianças de sete a doze anos, um de atividades para professores e alunos e um de temporada que apresenta as exposições temporárias, as atividades de atelier, as coleções permanentes, os espetáculos, a universidade popular, os eventos cotidianos, as práticas do museu e a agenda de exposições e espetáculos.

"O Quai Branly oferece um amplo espaço sem divisórias, onde são exibidas mais de 3.500 obras da áfrica, da Ásia, da Oceania e das américas. Vários documentos afirmam que a ausência de paredes divisórias tende a favorecer as "comunicações" e os intercâmbios entre as civilizações. O visitante pode experimentar a fluidez comunicativa ao percorrer o museu, vendo roupas, máscaras, armas, pirogas e instrumentos musicais colocados em vitrines, sem que a estrutura seja evidente. Tudo está ambientado com mapas, imagens fixas e animadas, além de músicas e dispositivos cênicos multimídia que sugerem contextos multiculturais. O percurso é concebido pelo arquiteto e por museógrafos como uma série de passagens por túneis e cavernas, desfiladeiros escuros, nos quais se destacam as vitrines ou os descansos mais iluminados onde se exibem as peças. Do lado dessas não há contextualização; apenas textos que introduzem as salas e uns poucos vidros com cerimônias ou cenas cotidianas dos povos representados. Explicações escassas, e, sobretudo, a penumbra geral, em vez de comunicar os significados das peças e dos desentendimentos ou conflitos históricos entre culturas, atestam uma estetização uniforme. As obras africanas, asiáticas e americanas, e as diferentes regiões de cada continente, ficam "integradas" em um mesmo discurso. Não há, com pouquíssimas exceções, datas nem localização histórica e social. Tudo conflui - objetos de diferentes épocas, vídeos de selvas música high-tech - em um espetáculo único que torna operativos, nas palavras de James Cliffort, "o universalismo estético de Chirac e a ambientação místico-natural de Nouvel" (CANCLINI, 2012, p.103). 


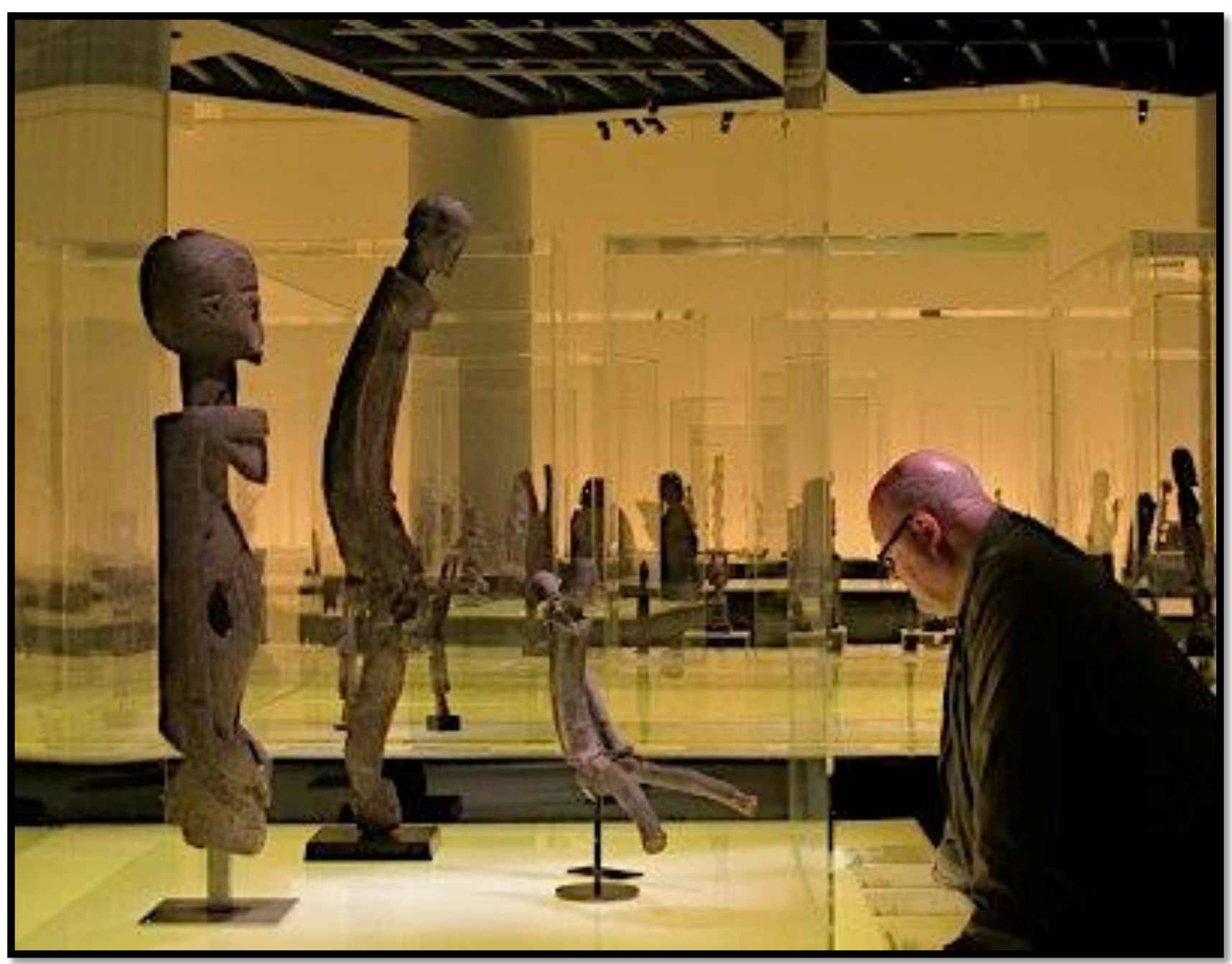

Figura 11 - Visitante diante da vitrine com o conjunto de esculturas Niongom. Exposição DOGON, Museu do Quai Branly, Paris, 2011. 


\section{2 - O MALI E OS DOGON}

\section{1 - OS DOGON}

A identidade Dogon é recente, constituiu-se progressivamente na diáspora, a partir do século $\mathrm{XV}$, através do contato com culturas já estabelecidas e em função de sua relação com outros grupos étnicos.

"Dogon é "aquele que pertence à família de quem tem senso de honra", sendo que "honra" significa não se casar fora da etnia. "Dogon" significa "Dogon", ou seja, "aquele que se casa apenas dentro do círculo Dogon e segundo suas regras". (BOUJU, 1995, p.333).

Povo que nasce em consequência das tradições migratórias, conhecedor de muitas línguas, não se organizava em torno de um Estado centralizador, nem em torno de um único rei. Cada agrupamento tinha o seu próprio chefe religioso, geralmente um ferreiro, "Hogon", sempre escolhido entre os mais idosos, eles tinham a função de produzir as ferramentas para a agricultura, o entalhe das esculturas e das máscaras para os cultos religiosos. Os ferreiros eram líderes religiosos, responsáveis pela garantia da ordem das coisas terrestres e da vida em sociedade. Tanto a vida trabalhosa e agitada de Bandiagara quanto a vida cultural dependiam deles porque eram eles quem faziam as esculturas, 
base dos rituais religiosos e base dos ensinamentos conferidos à iniciação. Como escultores, estavam estritamente ligados a um sistema de representações na ordem mítica e ritual da qual eram intercessores e mediadores.

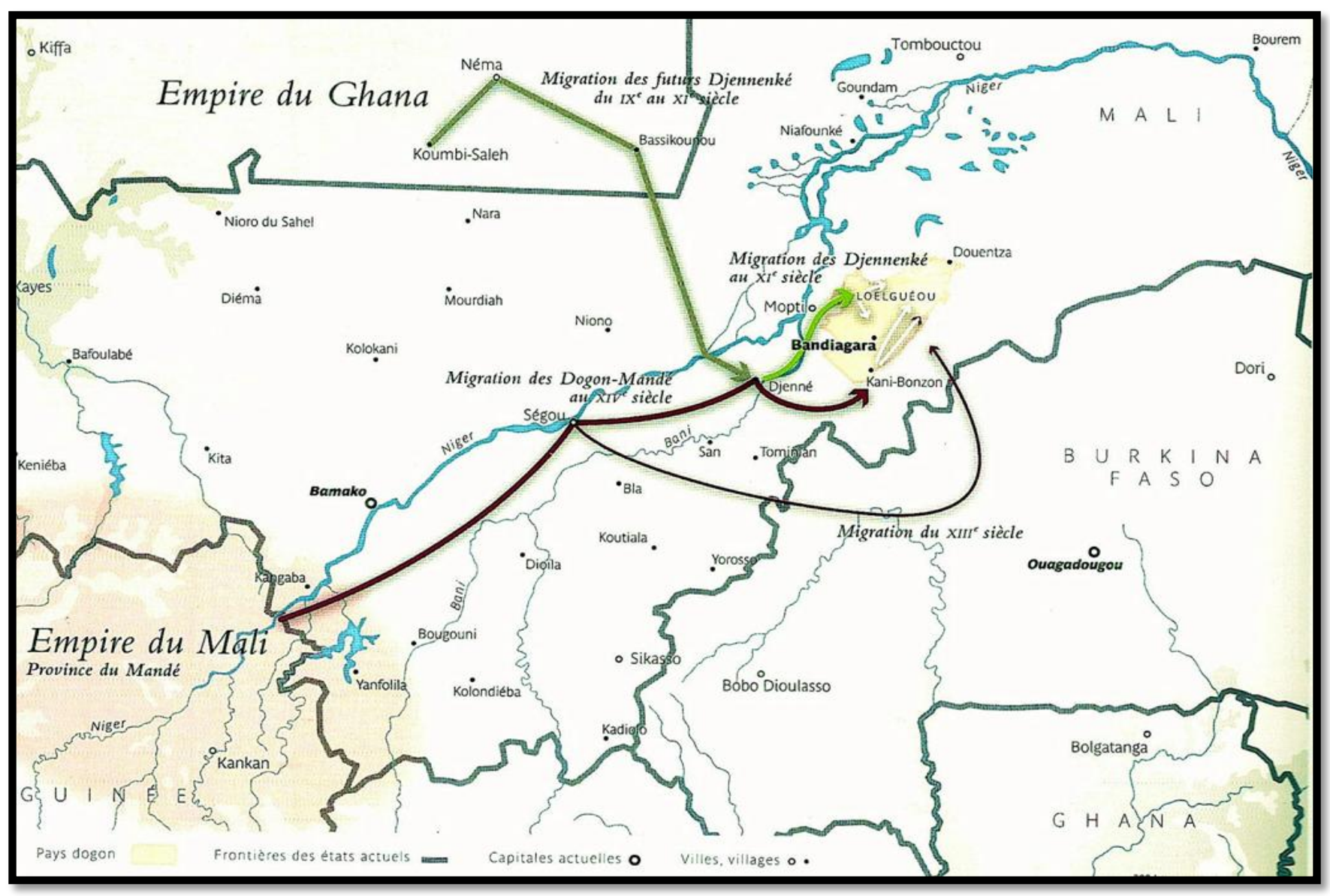

Figura 12 - Processos migratórios dos Dogon para a falésia de Bandiagara nos séculos IX, IX, XIII e XV. Fonte: Catálogo DOGON, Paris, 2011 
Os Dogon resistiram ao intenso processo de islamização e ao domínio dos reinos do Mali. Por terem vencido diversas pressões históricas e preservado suas tradições seculares, esse povo é reconhecido como uma das sociedades mais complexas e originais do planeta, conservando uma estreita relação com o meio ambiente, a cultura e a religiosidade.

[...]os Dogon elaboraram uma percepção dinamista da criação e da ordem das coisas e dos homens. Eles revelaram aí o confronto de "duas forças contraditórias e opostas" que garante a "marcha para frente", à medida que há "triunfo do lado da ordem sobre o lado da desordem". Eles não negam a agitação e a necessidade de frequentes e novas recolocações das coisas em equilíbrio; aceitam-nas, temendo, ao mesmo tempo, a irrupção do absurdo. Eles reconhecem a intervenção da liberdade humana e da invenção [...] (BALANDIER, 1976, pp 211 212).

A cosmogonia é uma das fontes para se compreender as origens dos Dogon, assim como o clã, a linhagem e a família são essenciais e estão extremamente presentes em sua identidade.

São múltiplas as versões sobre a chegada dos Dogon em Bandiagara: foram diversas ondas migratórias em busca de terras cultiváveis e abrigo até chegarem na falésia, que, naquele momento, estava ocupada pelos Tellem. 
"Os Dogon, em seus relatos oficiais, afirmam que ao saírem do Mandê, constituíram uma única família e, no longo percurso que realizaram, foram separando-se." (BARROS, 2004, p.25).

A cultura Dogon foi "descoberta" e popularizada pelos exploradores e pesquisadores franceses no início do século XX. Em 1905, o tenente Louis Desplagnes publicou as primeiras notas de campo e recolheu os primeiros objetos Dogon e Tellem. Em 1931, Marcel Griaule conduziu a missão DakarDjibouti e, ao chegar em Bandiagara, sua equipe encontrou pela primeira vez os Dogon de Sanga e começou a reunir, numa coleta interdisciplinar, uma rica documentação sobre as tradições e a religião Dogon.

"Em algumas décadas, a islamização do planalto de Bandiagara e o crescimento dos contatos com o ocidente induziu uma transformação no modo de vida Dogon. A indústria turística cresceu consideravelmente constituindo entre eles um complemento indispensável de recursos para a agricultura. [...] O quadro social tradicional da identidade Dogon situa-se no comércio informal, no seio de uma sociedade modernizada. Cada indivíduo pertence a uma série de grupos concêntricos: ele é membro de uma linhagem, de um clã, de uma vila que, sendo Dogon é enfim malinense. Os valores tradicionais tal qual a harmonia e o respeito com os mais velhos e aos objetos rituais, são compartilhados por todas as gerações. Alguns dos quatrocentos mil Dogon que hoje habitam o planalto estão preservando, adaptando e recriando a sua cultura" (LELOUP, 2011). 


\section{2 - A COSMOGONIA DOGON}

Para os Dogon, a palavra Amma significa o Deus Supremo, aquele que criou o mundo. Amma criou uma placenta, o "ovo do mundo", na qual implantou dois gêmeos andróginos. Um deles, Ogo, se revoltou e saiu da placenta, transformando-se em um som que se propagou sobre a Terra; porém, tornou-se solitário e procurou seu irmão gêmeo para juntos penetrarem as entranhas da Terra, sua mãe. Nesse ato incestuoso, Ogo amenizou o caos com os descendentes de Amma. Para punir Ogo, Amma transformou-o em uma raposa e, para dar fim à desordem, sacrificou o outro gêmeo, Nommo, cujo corpo fora desmembrado para o nascimento dos astros, assim como das plantas e dos animais. A partir daí, de uma minúscula semente, Amma fez eclodir o resto da criação. Com um pedaço de placenta fez uma arca para embarcar todas as suas criações. Nommo ressuscitou junto com quatro outros casais de gêmeos. A arca foi lançada sobre a terra. A primeira chuva caiu, formando o primeiro mar e o sol nasceu pela primeira vez.

"O Deus criador organizou o universo e essa ordem foi regida por leis que pertenceram ao homem para que ele pudesse compreender o seu lugar por si próprio" (CALAME-GRIALE, 1996).

Em 1965, Marcel Griaule e Germaine Dieterlen piblicaram "Le Renard Pâle", (A raposa pálida), onde estudaram a arte e a cultura Dogon. Já na introdução, Dieterlen chama a atenção para os primeiros ocupantes da região da Falésia, os Kourouba, os quais foram chamados de Tellem pelos Dogon vindos do Mandê. 
"A estrutura social das diferentes populações, reconhecem as linhas de parentesco ou aliança e, entre elas, uma origem comum, baseada em princípios análogos marcados por um mito cosmogônico idêntico. As manifestações rituais, aparentemente diferentes, reconhecem as mesmas crenças e procedem de uma estrutura mental semelhante. No interior desse sistema, as formas sociais opostas são concebidas como complementares e voluntariamente instauradas - essa complementariedade é considerada como necessária para o funcionamento do todo" (DIETERLEN, GRIAULE, 1991).

A língua falada pelos Dogon empresta elementos mandê e voltaicos e não poderia ser classificada com absoluta certeza, pois é constituída por vários dialetos que possuem entre eles diferenças às vezes consideráveis de vocabulário e de morfologia; algumas das quais subdividem-se em subdialetos.

A aprendizagem das crianças é precoce porque os Dogon, conscientes da sua diversidade linguística, atribuem grande importância à pureza da língua que, para eles, é a parte mais importante do conhecimento.

A língua falada nos rituais é a Sigi, de estrutura simples, comportando apenas um quarto do vocabulário falado pelos Dogon. Os dignatários do Sigi, os Olubaru, são os únicos sacerdotes habilitados a declamar, na língua Sigi, os textos que relatam a criação do universo, da vida dos homens, da aparição da morte sobre a Terra, no decorrer das cerimônias funerárias e dos rituais de luto.

Entre os cultos mais respeitados está o culto ao Deus Supremo Amma, criador do universo. Em seguida vem o culto aos seres vivos e animados aos quais Amma confiou uma parte da gestão do universo e, especialmente, os três primeiros Nommo; os dois primeiros acompanham Amma pelo céu 
empírico e o terceiro é o pai dos homens, aquele que foi sacrificado no céu para reparar as falhas de seu irmão gêmeo. O quarto é o formador da Terra que fora transformado em raposa depois que ressuscitou.

O culto aos ancestrais possui quatro linhagens: os filhos do Nommo, respectivamente Amma Sérou, Lébé Sérou, Binou Sérou, Dyongou Sérou e seus gêmeos, os oito ancestrais, formando o ápice das quatro sociedades Dogon. A palavra Sérou significa testemunha e refere-se simbolicamente às funções dos responsáveis pelas principais religiões Dogon. Esses seres míticos são os "Olhos de Amma", os responsáveis em saber como o mundo funciona, os guardiões da vida, os detentores e protetores dos princípios espirituais dos homens e dos cereais, base da sua subsistência. São ao mesmo tempo agentes e testemunhas dos principais cultos e também representam os sacerdotes dos cultos que lhes são oferecidos.

O culto à raposa tem a função de revelar aos homens o seu destino através dos traços que ela deixa sobre a mesa de adivinhação feita na areia. Em todas as aldeias, os adivinhos são os sacerdotes do culto. As mesas de adivinhação permitem saber o que vai acontecer. O adivinho traça sobre a mesa uma série de desenhos que correspondem a algumas possíveis respostas. Ele dispõe em seguida de alguns alimentos destinados a atrair a raposa pálida (Le renard pâle), Yourougou. $\mathrm{O}$ animal que vem durante a noite para marcar algumas pegadas sobre as zonas da mesa de adivinhação. Pela manhã o vidente interpreta as adivinhações que Yourougou fez com suas patas. Yourougou, assim como o outro Ogo, fora transformado por Amma. Condenado a errar na escuridão e proibido de falar, ele não pode se expressar de outra maneira a não ser esganiçando cada vez mais na tentativa de revelar aos homens os segredos (através dos desenhos) de Amma (DIETERLEN, GRIAULE, 1991). 


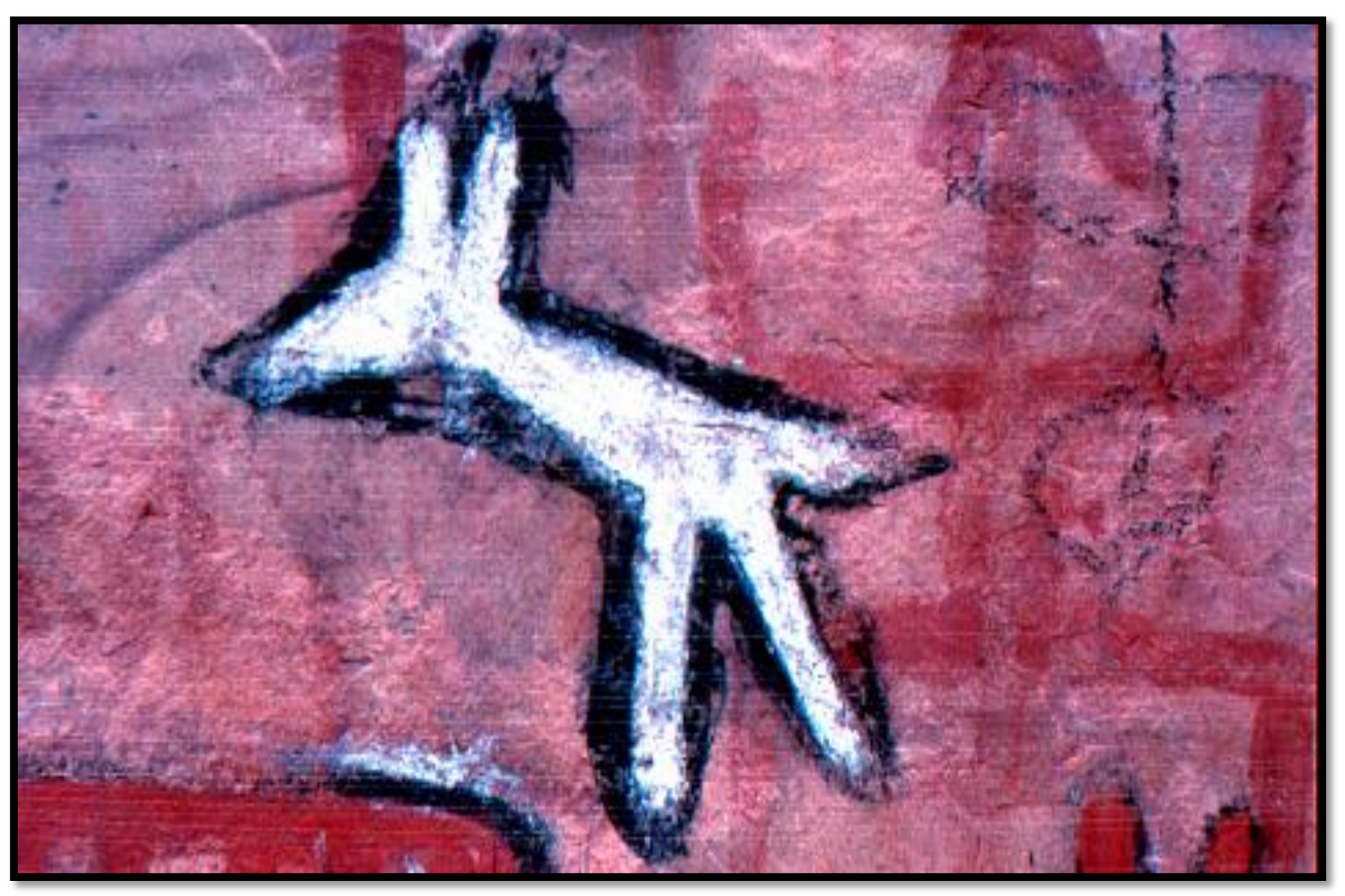

Figura 13 - Pintura rupestre: "Le renard pâle” (caverna de Songo - Mali). Foto de Jean Rouch. Fonte: http://rcfilms.com.sapo.pt/espelho.html 


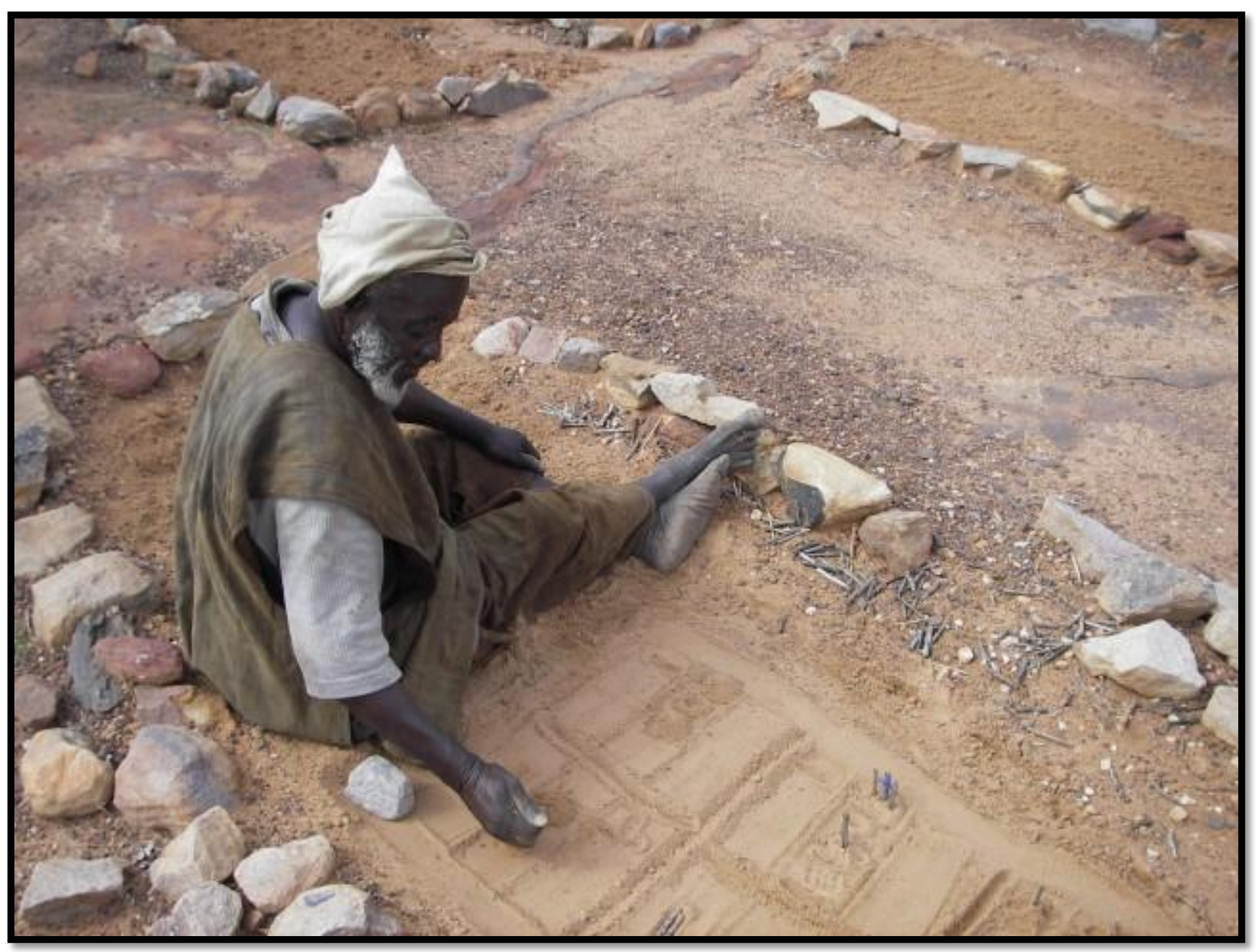

Figura 14 - Adivinho Dogon. Fonte: http://www.gestress.be/rando/MaliDogon.htm 


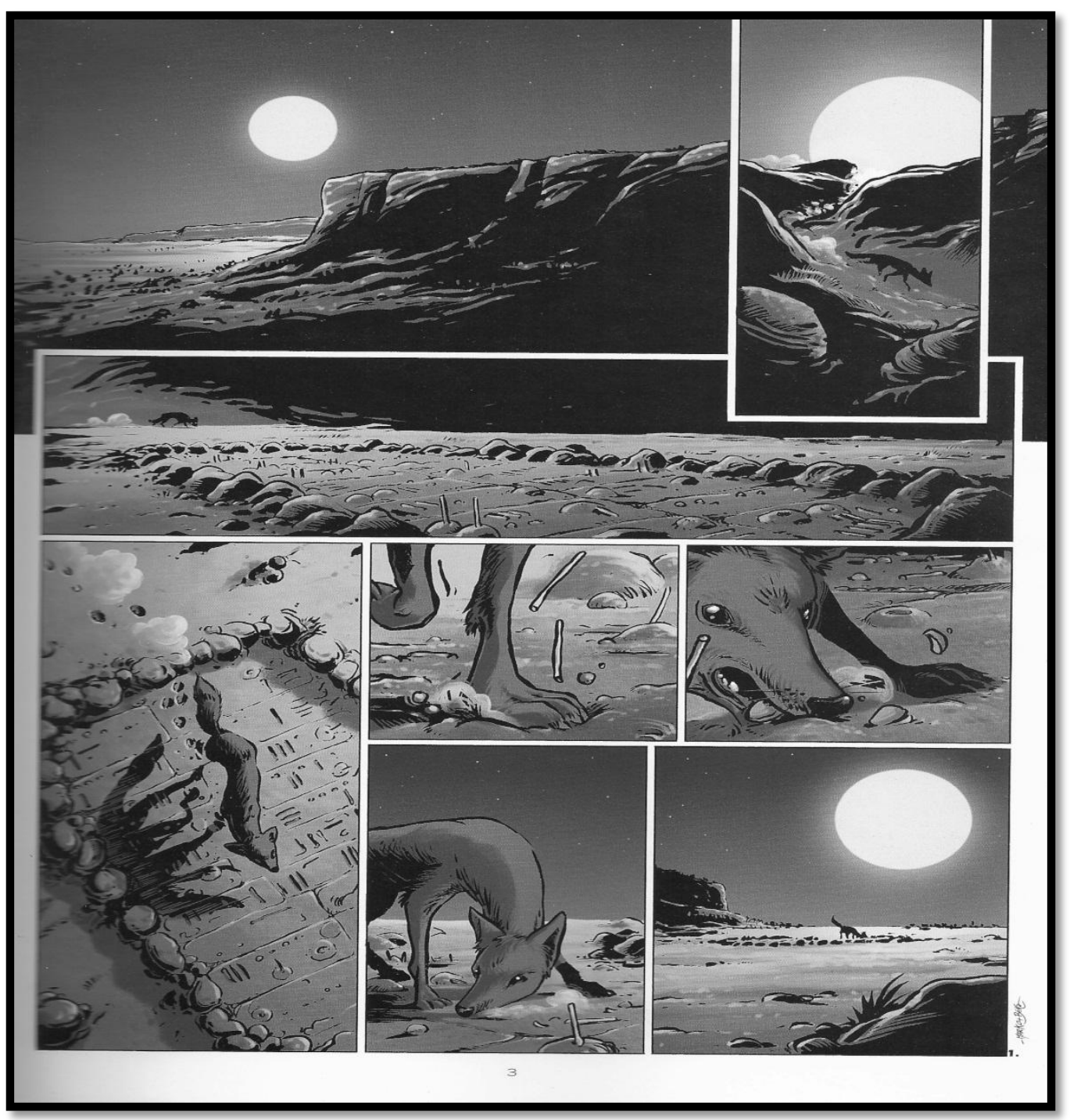

A Raposa Pálida é apreciada por seus dons de adivinhação. Ao se rebelar contra Amma, ela foi colocada fora das leis do universo e do tempo, o que the permitiu prever o futuro. Ao pôr do sol, longe da aldeia, os adivinhadores traçam na areia tabelas de adivinhação e deixam comida para atrair a raposa. No dia seguinte, os adivinhadores interpretam as mensagens deixadas pelo rastro das patas da raposa na mesa de adivinhação. 


\section{3 - A TERRA DOS DOGON}

O renomado Pays Dogon, (Terra Dogon), situa-se atualmente no centro-oeste da República do Mali a oitenta quilômetros da capital regional Mopti (Quinta Região Administrativa). Ele é formado por um planalto rochoso, uma região de planície e uma falésia conhecida como falésia de Bandiagara.

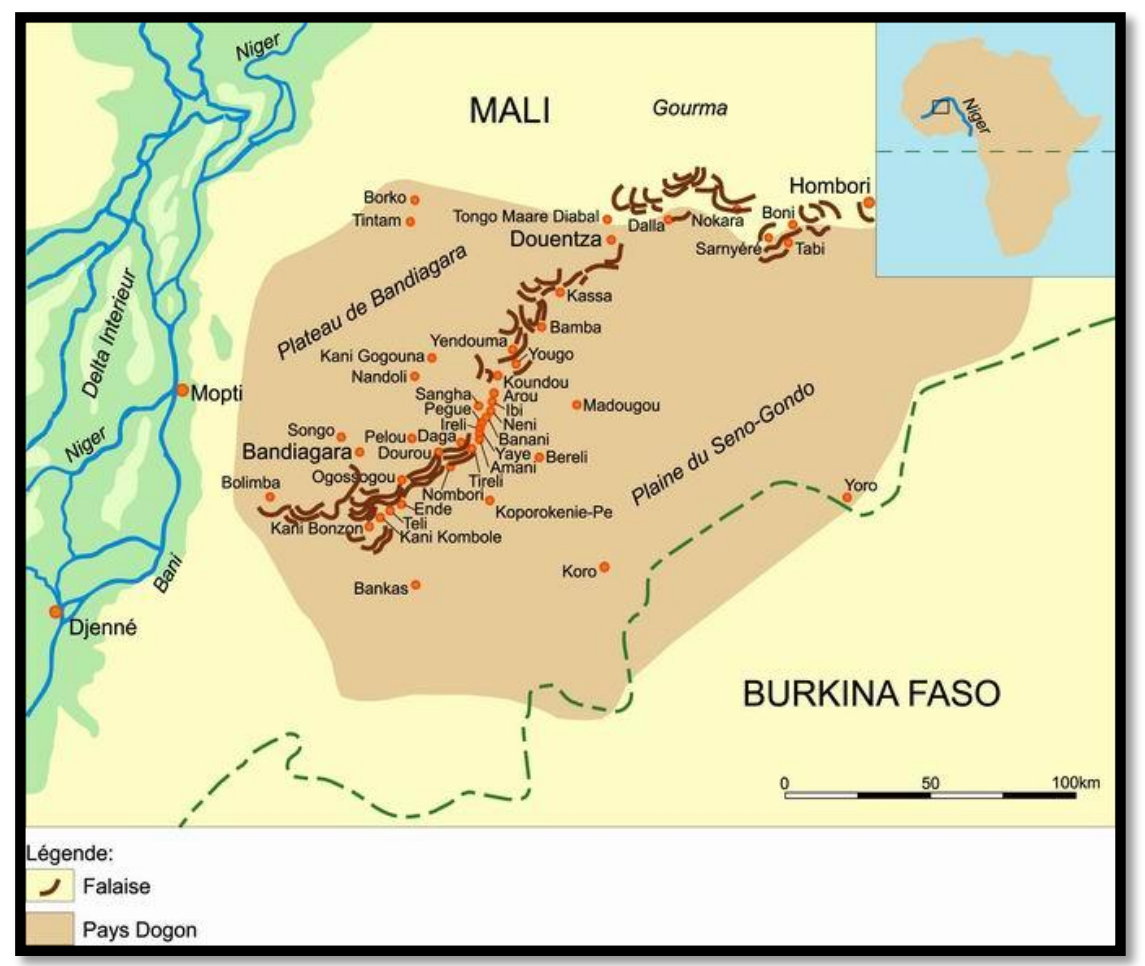

Fig. 16 - Mapa do Pays Dogon. Fonte: http://hupomnemata.blogspot.com.br/2010_03_01_archive.html 
A palavra Bandiagara significa a "grande banja", bacia ou prato Dogon onde se come coletivamente, e é também o nome do lugar onde outrora existia flora e fauna abundantes, lugar bom para a agricultura e a caça.

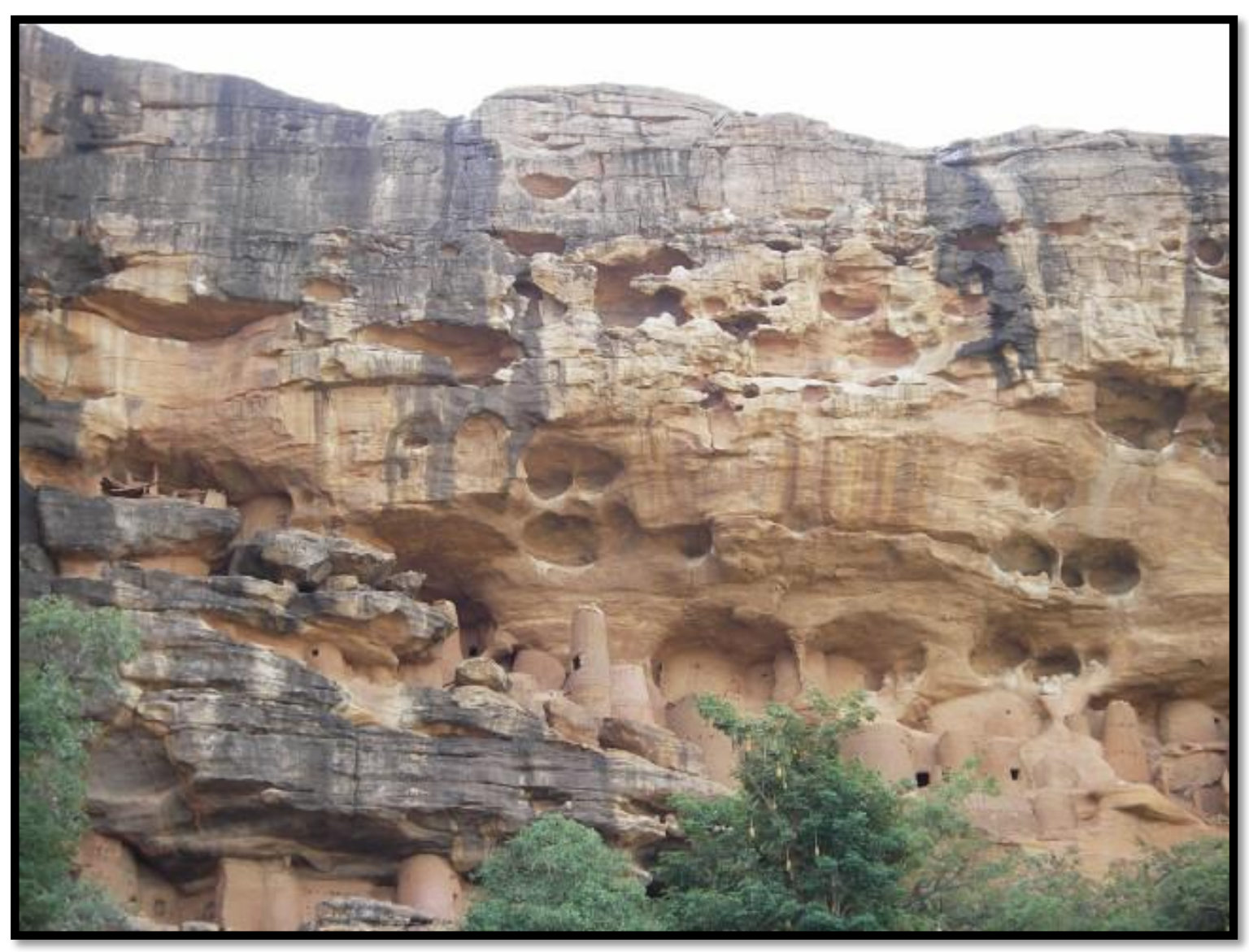

Figura 17 - Moradias Tellem na Falésia. Fonte:_http://www.gestress.be/rando/MaliDogon.htm 
Povoada majoritariamente pelos Dogon, a região vive essencialmente da agricultura de subsistência, cultivada em pequenas hortas espalhadas pela planície e o planalto, o que constitui grande parte da economia doméstica. Bandiagara concentra atualmente a maior aglomeração do planalto, somando mais de doze mil habitantes.

O planalto é um bloco maciço de pedras ferruginosas com uma altitude média de quatrocentos metros. A parte oriental é muito elevada, com mais de seiscentos metros, ainda que a parte ocidental se distinga por uma inclinação suave.

A falésia com vista para a planície, apresenta um traçado retilíneo. A parte setentrional é marcada por montanhas verticais abruptas. Seu ponto culminante é em Bamba, com 791 metros de altura. $O$ maciço de Tondo em Hombori é o ponto mais alto do Mali, chegando a 1.155 metros de altitude. Tradicionalmente, a falésia, com as suas vilas amontoadas, é a região mais populosa. Contudo, depois da seca de 1970, sua população preferiu descer para a planície vizinha para o sul do país, onde o problema da terra é bem menos complicado.

A planície, mais conhecida como Seno ("solo arenoso" na língua dos Fula), é formada por uma grande depressão e uma vasta região que comportam muitas lagoas. É constituída por duas unidades distintas: o Seno, uma vasta extensão de areia que se junta à falésia na parte sul, e o Gondo, uma imensa planície argilo-arenosa na parte oeste.

Em 1989, a UNESCO reconheceu e enalteceu o Pays Dogon, classificando-o como Patrimônio da Humanidade e se Ihe outorgou a denominação de Santuário Natural e Cultural das Falésias de 
Bandiagara, por relacionar a integridade e a autenticidade da preservação de suas tradições culturais e religiosidade ao desenvolvimento sustentável.

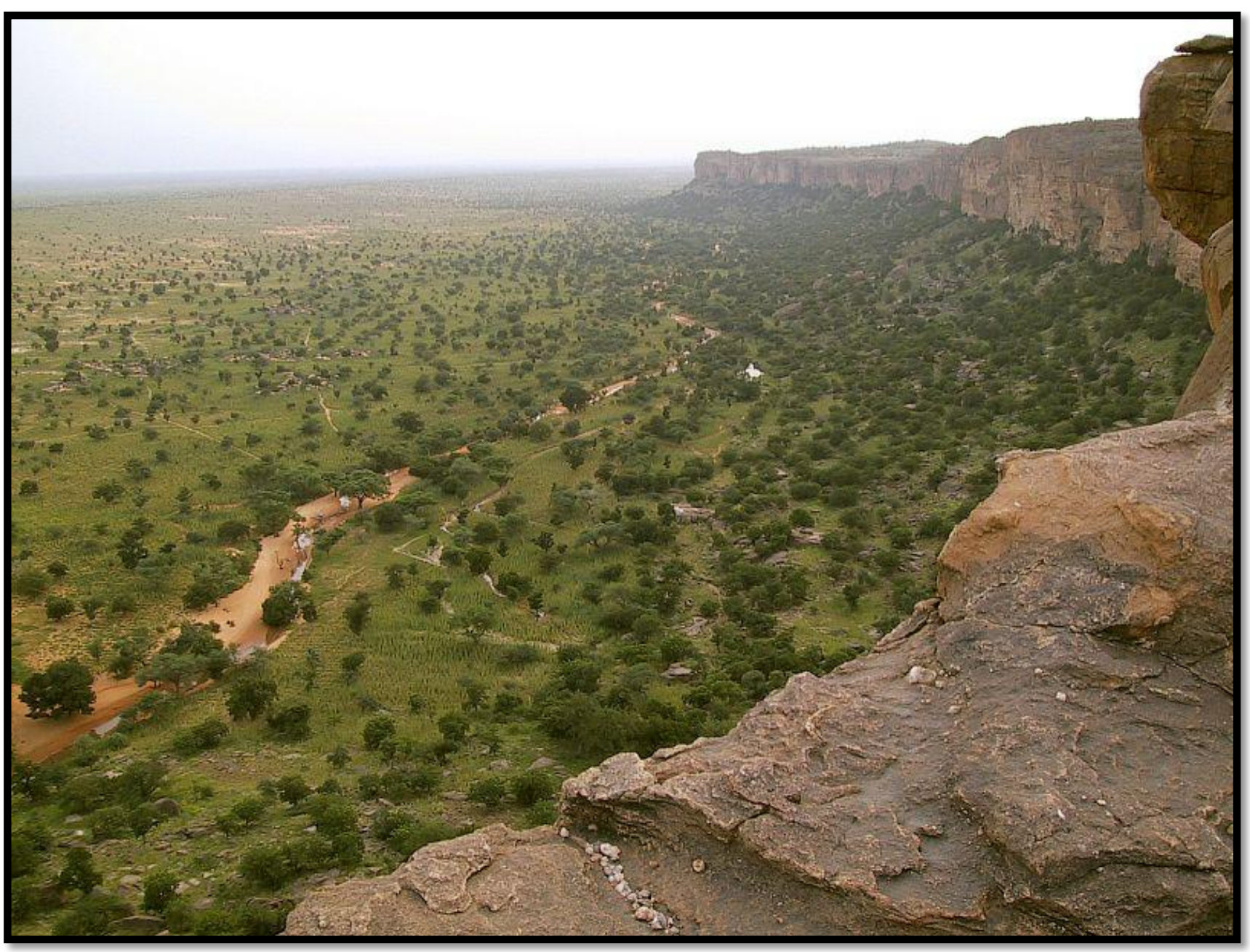

Figura 18. A Planície - Foto: Timm Guernther. Fonte: http://en.wikipedia.org/wiki/Bandiagara 


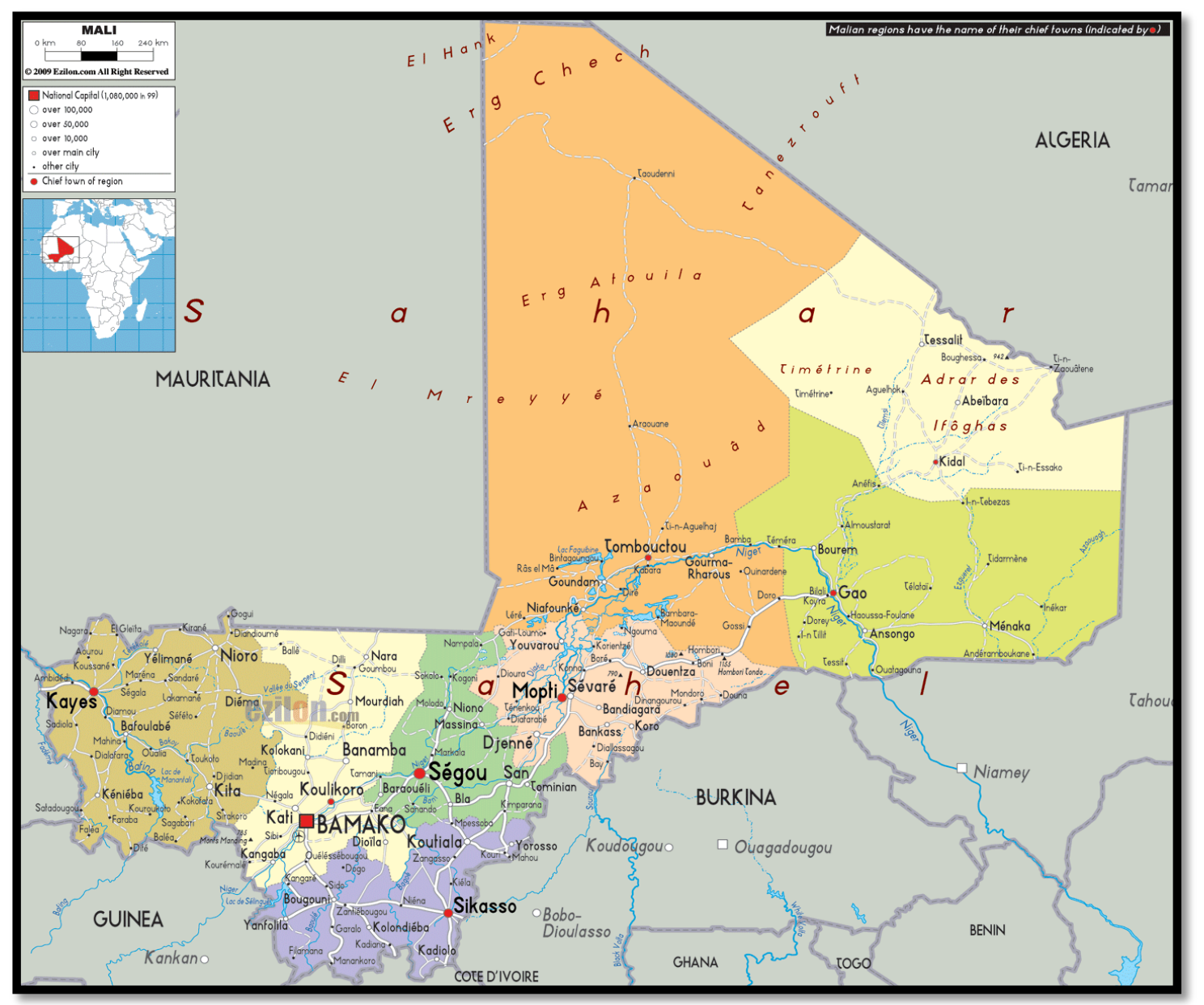

O Mali é o sétimo maior país africano, e localizado na região sul do Saara. Seu primeiro nome foi Bialal-al-Sudan "a terra dos negros", sua capital Bamako situa-se às margens do rio Níger, com população estimada em cerca de 14,5 milhões de habitantes. Compreende mais de vinte etnias, entre as quais estão os Mandingas, os Bambara, os Fulas, os Songais, os Senufos, os Bobo, os Bozo, os Dogon, os Soninkes, etc. Numa extensão de $1.241 .021 \mathrm{~km}^{2}$, sem saída para o mar, faz fronteiras com sete países: Argélia ao norte (em meio ao deserto do Saara); Costa do Marfim, Burkina Fasso e Guiné Konakry ao sul (onde há uma concentração bem maior de habitantes por conta da proximidade com os rios Níger e Senegal); Níger ao leste e Mauritânia e Senegal a oeste.

Fonte: http://www.infopedia.pt/\$mali

Figura 19 - Mapa político da República do Mali. Fonte: www.wpmap.org/wp-content/uploads/2012/04/political-map-of-Mali 


\section{3 - LUGARES DE PRODUÇÃO}

\section{1 - A ESCULTURA DOGON}

A escultura Dogon esculpida em madeira distingue-se por sua ampla diversidade estilística e variedade formal. São peças criadas a princípio como instrumentos de intermediação no culto às divindades religiosas e aos ancestrais e ascendentes, mas também podem ser encontradas na ornamentação de ferramentas e instrumentos de uso cotidiano. Em geral, são esculturas de pequeno e médio porte entalhadas em madeira dura, e representam de imediato, figuras esguias com troncos alongados e braços levantados, figuras equestres, maternais, casais abraçados, duplas tocando xilofone, figuras ajoelhadas, figuras cobrindo o rosto, figuras sobrepostas, taças cerimoniais, encostos de cabeça, bancos, fechaduras, portas e janelas de celeiros. Esses objetos fazem parte da cultura Dogon e estão presentes no cotidiano das sociedades, revelando sua religiosidade, rituais e costumes através de um alto conhecimento e refinamento estético. Não se trata de objetos concebidos apenas com finalidades estéticas definidas ou para serem apresentados como obras de arte, cabe a cada escultor adaptar o seu estilo a uma determinada função. A obra esculpida é o veículo, o agente e o modo de transmissão de conhecimento (BOUJU, 1994).

"Não existe definição de arte que possa ser comum a todas as sociedades, uma vez que as normas estéticas variam conforme as regiões, as épocas; dificilmente um objeto terá uma linguagem universal, capaz de superar contingências das barreiras culturais. Talvez possa apreciar sua forma, mas seu sentido, seu conteúdo, permanecerá inacessível ao apreciador estranho ao meio social que a gerou" (SILVA, 2007; 23). 
A arte estatuária produzida pelos Dogon é em sua grande maioria escultura entalhada em madeira, e pode ser considerada uma das que mais se destaca, se comparada às outras sociedades produtoras de arte em África. Atualmente a escultura Dogon tem sido considerada a mais estudada e cobiçada por galeristas, pesquisadores, colecionadores e iniciantes no universo das Artes Primeiras.

"Distinguem-se na sociedade Dogon, os ferreiros e aqueles que trabalham com o couro, cujas mulheres são tintureiras. Os ferreiros não cultivam, mas fabricam os instrumentos para o trabalho do campo em troca de cereais, vivendo em povoados à parte ou isoladamente na periferia das localidades; entretanto, não extraem o minério da terra. Ainda que as esculturas em madeira possam ser realizadas por qualquer Dogon, os ferreiros são, também, reconhecidos mestres da madeira, construindo e entalhando as portas das casas e dos celeiros e suas fechaduras, além de estatuetas e objetos destinados a diferentes cultos [...]" (BARROS, 2004, pp. 30, 31).

Devido às sucessivas levas migratórias em direção ao país Dogon, tornou-se inevitável o encontro entre diferentes culturas, o que possibilitou a criação de uma arte escultórica expressiva, refinada, múltipla e diversificada. É possível identificar os estilos correspondentes aos povos, seja em relação às regiões de Bandiagara, às especificidades culturais ou mesmo às suas diferentes épocas de produção. 


\section{2 - ESTILOS DA ESCULTURA DOGON:}

Algumas obras podem ser atribuídas a um atelier específico, precisamente designadas por um nome de convenção, por exemplo: as figuras de braços levantados Tellem; as mães curandeiras Tintam; as figuras hermafroditas Niongom; os cavaleiros N'Duleri; os tocadores de balafom Dogon-Mandé; as figuras hermafroditas com braços levantados Djennenké; a figuras sentadas com as mãos nos olhos Kambari.

"O modo como são tratados, na escultura, os emblemas e os símbolos ligados à presentificação dos deuses e dos antepassados constitui um interessante testemunho da extraordinária liberdade que 0 artista africano consegue preservar, ainda que observando convenções estritamente definidas" (BALOGUN, 1977).

A análise dos estilos pode ser feita por categorias, técnicas, temas e a habilidade expressiva do escultor onde podem ser observadas as marcas rituais, as escarificações, as vestimentas, os penteados, as posições dos corpos, os gestos e o formato dos elementos que compõem o rosto.

"Quando se trata da caracterização dos estilos é conveniente observar com a maior prudência. O objeto apenas - como um sistema de formas, que deve ser analisado, cuja análise deve permitir sua classificação num grupo determinado. Se o lugar onde foi adquirido um objeto é conhecido, nada indica que foi ali que a peça foi feita e nem mesmo onde ela tenha sido utilizada" (LAUDE, 1994). 
À análise das obras juntam-se componentes iconológicos (estágio inicial de investigação), etnológicos (estágio da busca de conclusões fundamentadas), e antropológicos (estágio da solução e continuidade), sendo que a preferência por um desses termos exprime apenas a predominância da atenção voltada para um desses tipos de pesquisa que sempre há de considerar os dois outros.

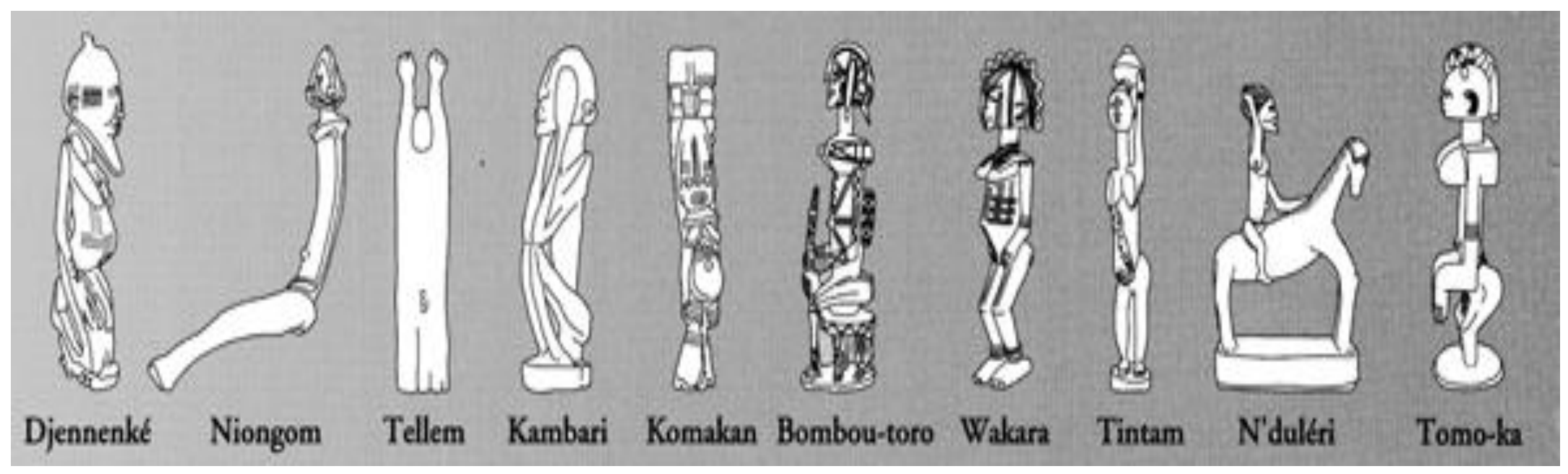

Figura 20: Alguns dos vários estilos da Escultura Dogon apresentados em texto de Hélène Leloup para a exposição Escultura Dogon no Museu Dapper, Paris, em 1994. 


\section{MAPA DOS ESTILOS DA ESCULTURA DOGON POR REGIÃO}

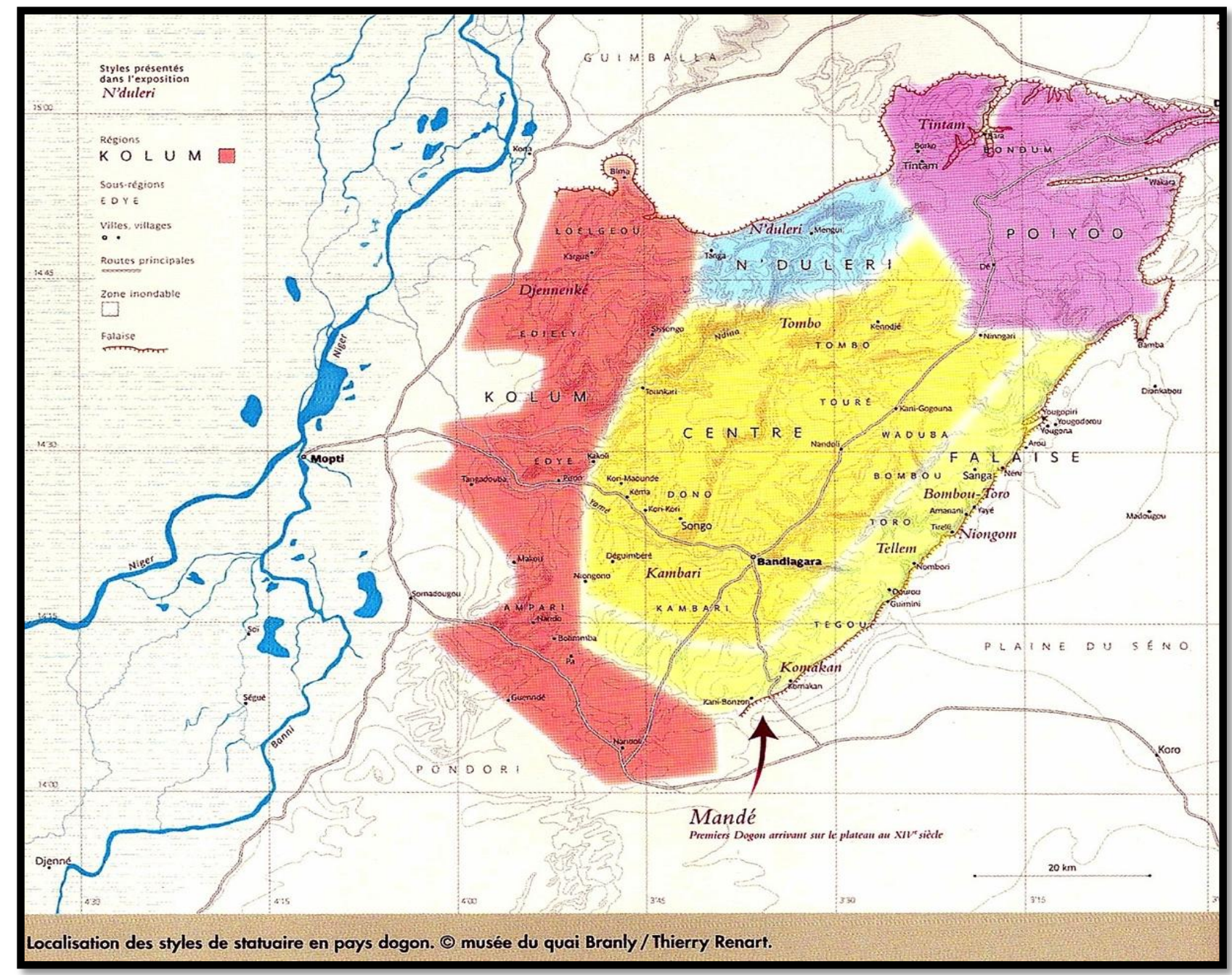

Figura 21: Mapa da localização dos estilos de esculturas no país Dogon. Fonte: Catálogo DOGON; Hélène Leloup, 2011
O País Dogon é dividido em cinco regiões. Cada uma com sua produção escultórica distinta: na região Central (Tombo e Kambari), na Falésia (Komakan Tellem, Niongom, e Bombou-Toro), na Poiyoo (N'Duleri e Kolum), em N'Duleri (N'Duleri) e no Kolum (Djenennké). 


\section{2 - ESCULTURA MANDÊ}

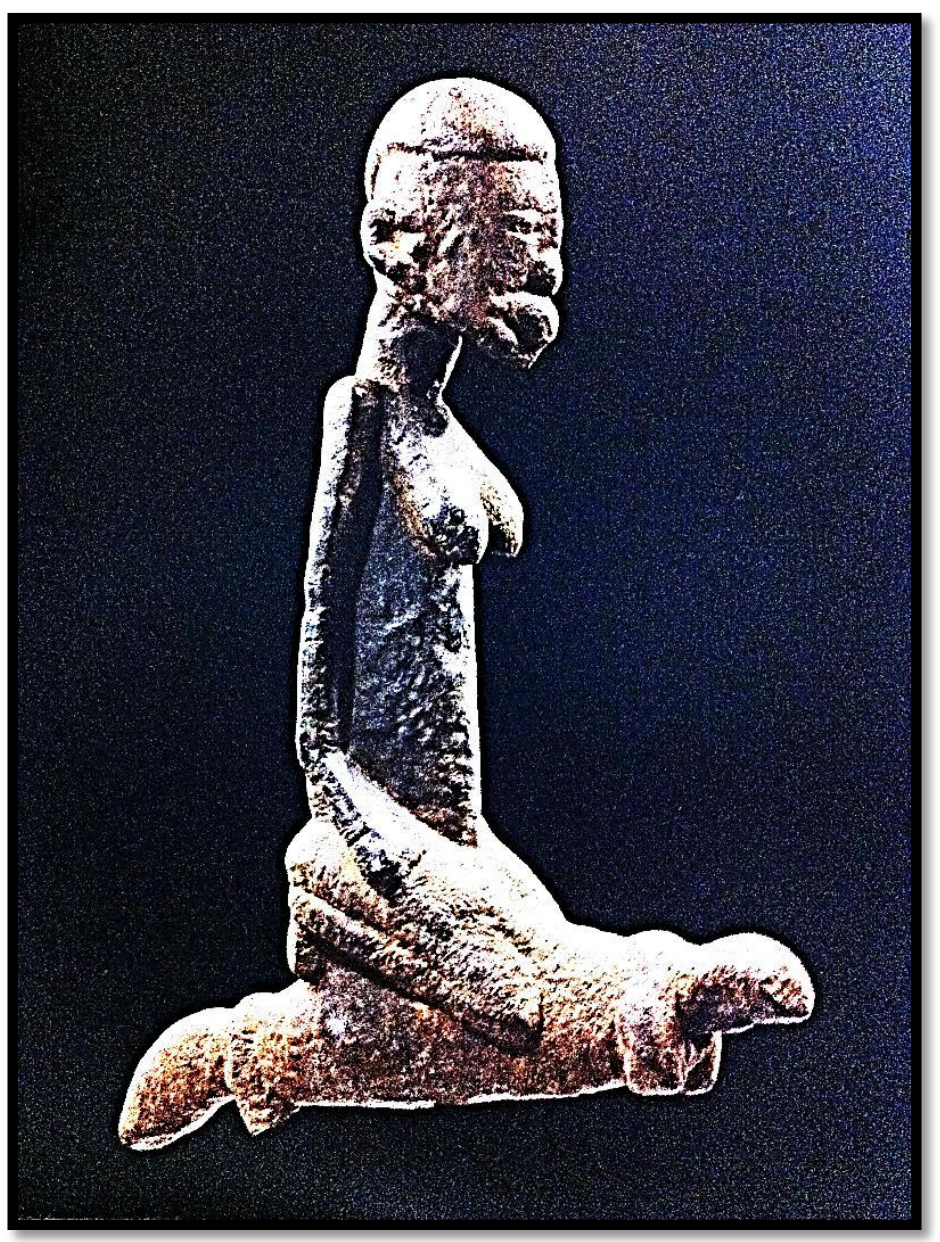

Uma figura feminina montada num animal anfíbio, provavelmente um crocodilo ou uma tartaruga, pode ser a presentificação de um episódio associado ao mito da travessia do Rio Níger durante a migração dos Dogon Mandê para a falésia de Bandiagara.

Figura 22 - Cavaleira, Madeira, 81 cm, Século XVIII-XIX, Antiga Coleção Lester Wunderman, Museu Dapper, inv. 00778, Paris, França. Fonte: Catálogo DOGON, 2011. 
O termo "Mandê" designa os Dogon originários de uma província homônima do Império do Mali, situada a sudeste de Bandiagara. Foram os primeiros a chegar na falésia no século XIV. Seu estilo frontal "clássico" de escultura aparece no século XVI. As esculturas Mandê são imediatamente reconhecíveis por imitar o estilo Tellem em seu gesto ritual de clemência pela chuva. Elas formam um conjunto inédito de figuras "em atividade".

Segundo a etnóloga francesa Germaine Dieterlen, para a qual a fonte da iconografia Dogon reside principalmente no mito, a ligação entre a iconografia de um objeto e sua função não é literal e exemplifica com a leitura de uma escultura dos tocadores de balafom ou xilofone (fig.25), criados talvez para lembrar um episódio do mito de origem, para o qual existem várias versões; as esculturas de mulheres com crianças (figs.23 e 24), podem ser interpretadas como uma alegoria à fecundidade, mas muitas vezes também podem ter finalidade terapêutica ou funerária; estátuas de mulheres pilando o milho podem ser interprestadas como se estivessem modelando o primeiro pote em argila a ser utilizado em um ritual específico.

As maternidades geralmente são representações de mulheres amamentando, com uma ou mais crianças em seus braços. Sua função é celebrar a fecundidade para continuidade do grupo. São representações simbólicas da "mãe", aquela que dá a vida, dotada de energia vital, que alimenta, protege e harmoniza a vida social. São figuras arquetípicas do princípio de vida e representam a comunidade inteira em seus fundamentos, com todas as virtudes ligadas a ela: o dom da amamentação, a bondade e a prosperidade (BLANC, 2011).

Com o seio na boca, além do leite, o que escorre é a transmissão de valores. 


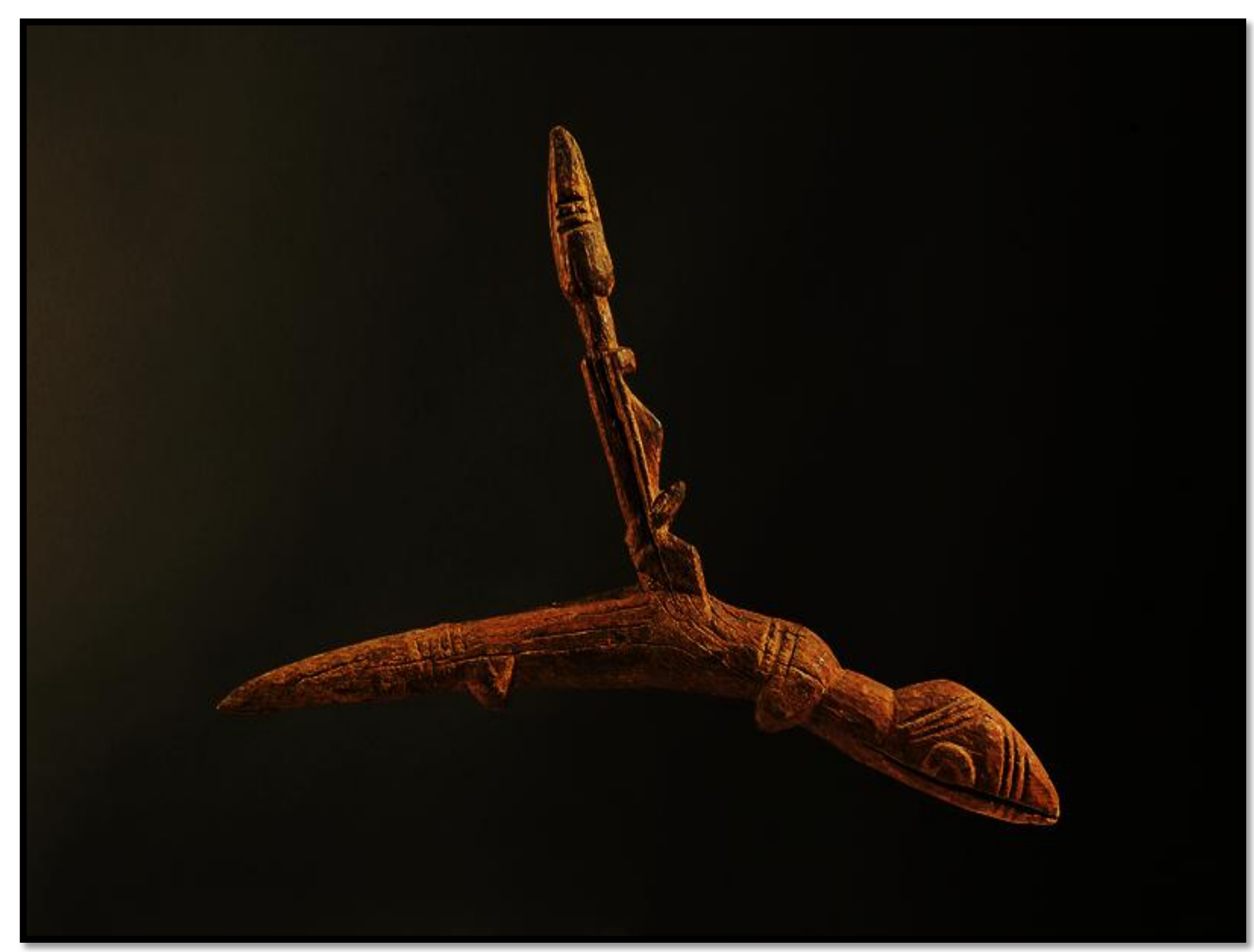






Figura 24 e 25 - Maternidade, Mandê, Cento-Oeste do planalto de Bandiagara, fim do século XVIII, madeira dura com patina rachada, $69 \mathrm{~cm}$. Paris. Coleção particular. 


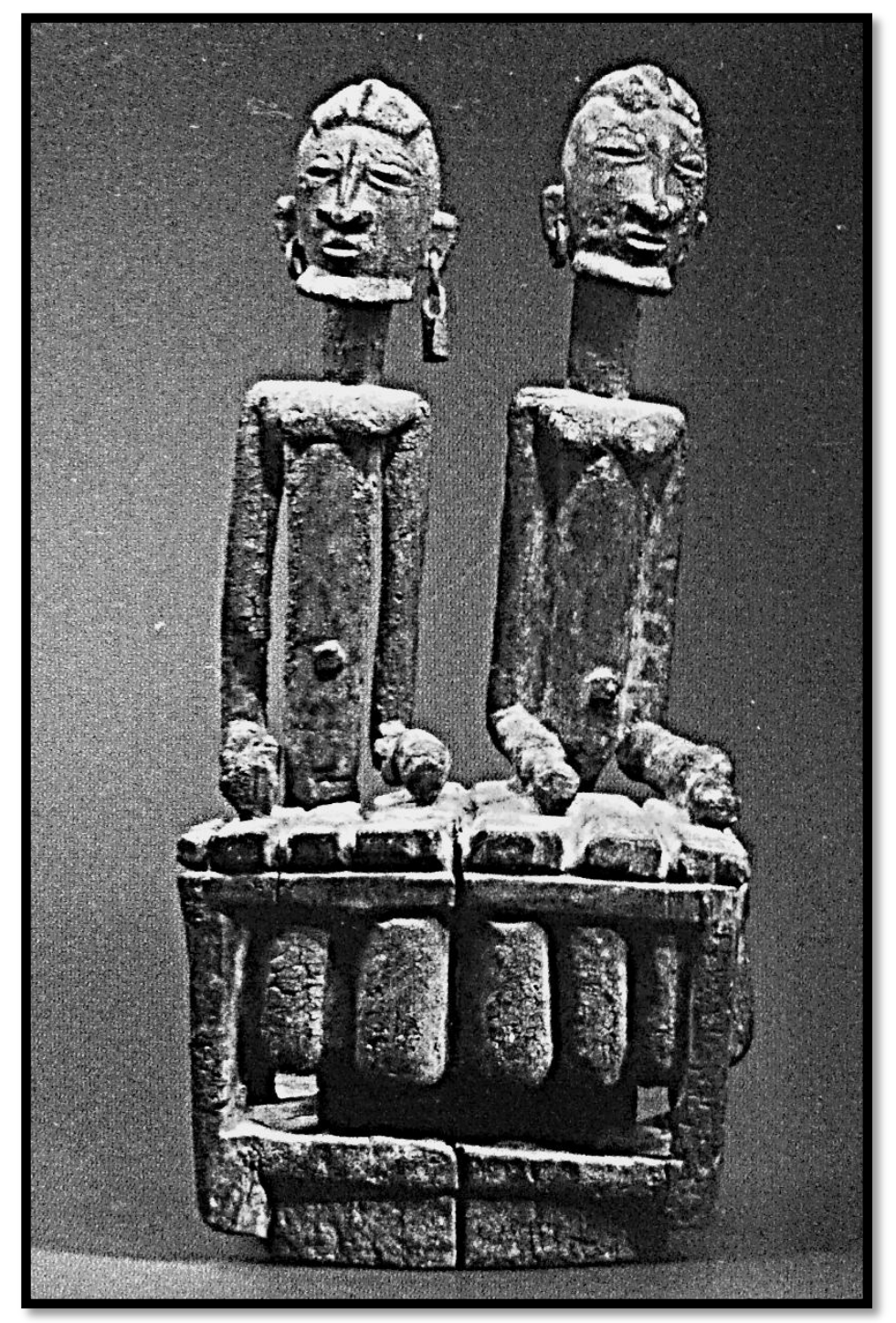

$\mathrm{Na}$ escultura dos tocadores de xilofone podemos perceber que as figuras são quase iguais e estão quase na mesma posição, porém, existem diferenças sutis; suas cabeças estão ligeiramente voltadas para lados opostos, uma tem o pescoço maior, os brincos de metal são diferentes, os umbigos estão em níveis diferentes e os cabelos não tem o mesmo corte, embora à primeira vista pareça que sim. As figuras são estilizadas, o tronco e os braços são alongados na vertical, mas o instrumento foi entalhado com realismo a ponto de podermos diferenciar as cabaças, que funcionam como caixas de ressonância, das madeiras na posição horizontal que formam o teclado.

Figura 26 - Tocadores de Xilofone, Séculos XV-XVI, Madeira patinada com brincos de ferro nas orelhas. $44 \mathrm{~cm}$. Coleção particular, Paris, França. 

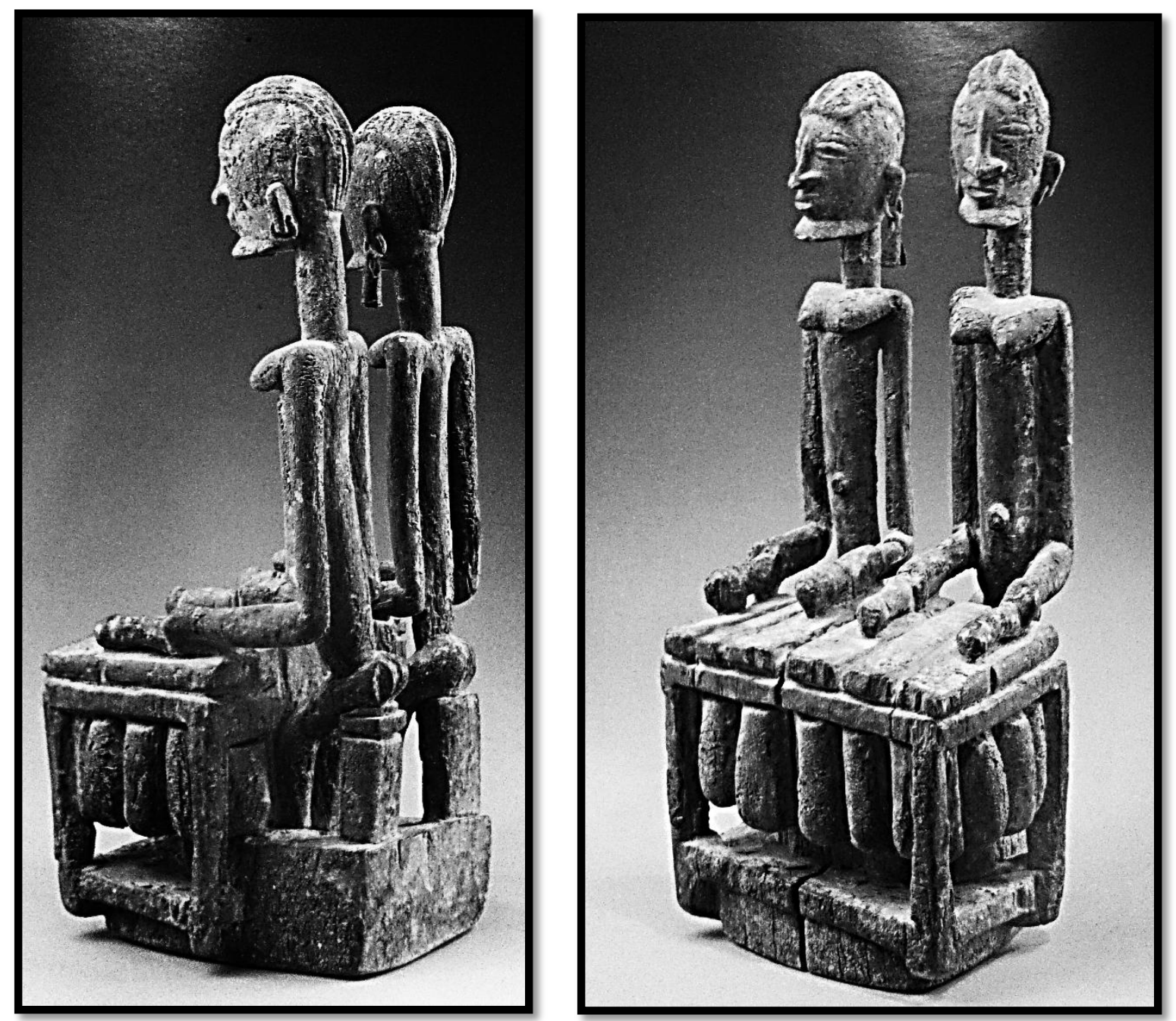

"Essa obra, considerada como uma das mais belas esculturas da coleção Dogon, é notável pelo rigor de sua construção e refinamento. Além disso, a raridade e o interesse de seu tema, conferem-Ihe uma importância histórica inigualável, como testemunho do passado deixando para cada geração um registro material de origem mandinga" (LELOUP, 2011, p. 254)

Figuras 27 e 28 - Tocadores de Xilofone, Séculos XV-XVI, Madeira patinada e brincos de ferro. $44 \mathrm{~cm}$. Coleção particular, Paris, França. 


\section{3 - ESCULTURA KOMAKAN}

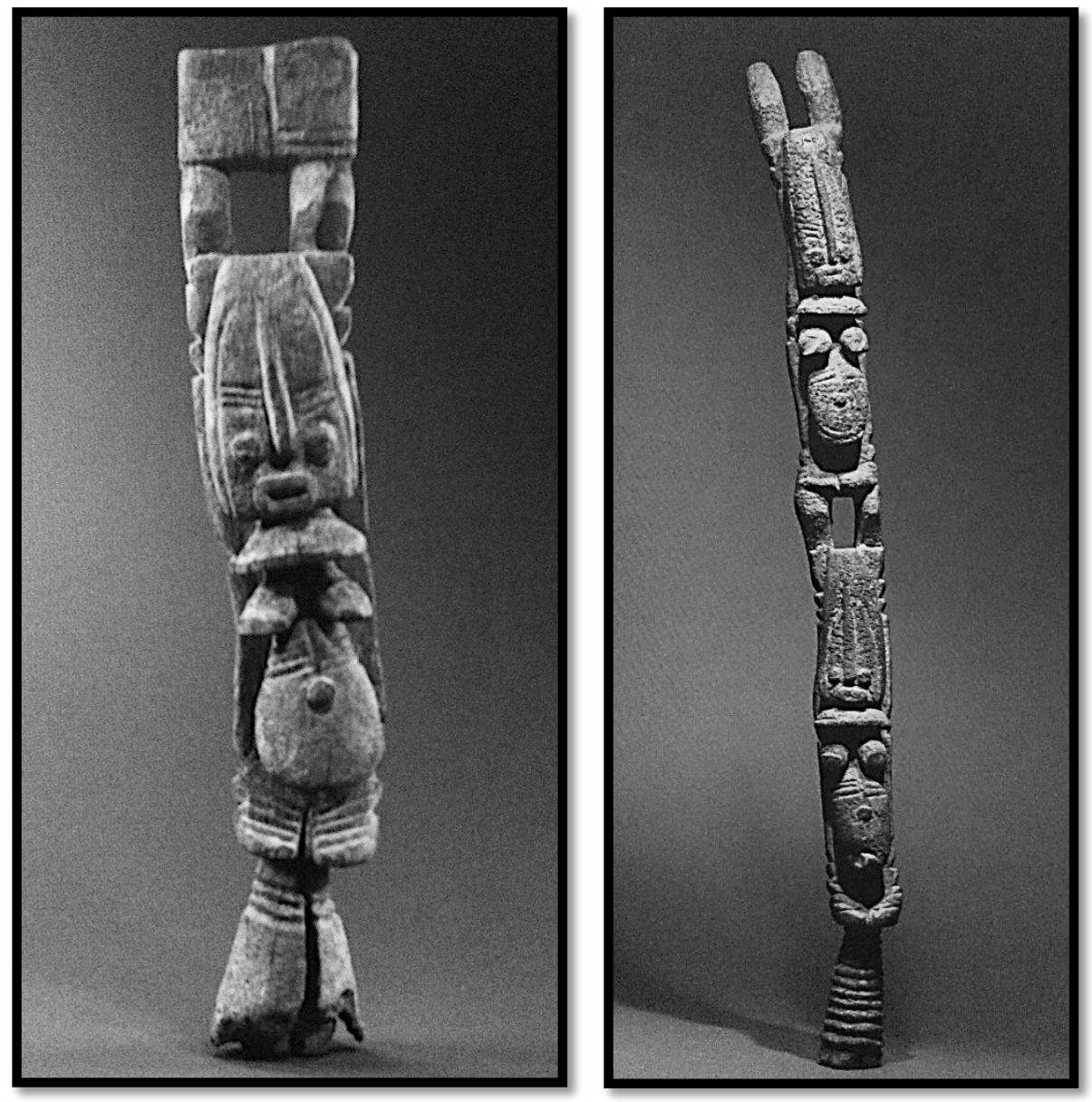

Contemporânea das culturas pré-Dogon do sul da falésia, a escultura Komakan distingui-se por uma produção onde a linha não é o principal vetor da expressão. Boa parte dessas esculturas são figuras de braços erguidos e personagens em forma de escadas, simbolizando possivelmente a continuidade da linhagem. São blocos superpostos, nitidamente separados, de onde brotam ventres, seios, barbas, lábios elípticos e olhos redondos, separados pela linha vertical do nariz que aumenta e prolonga a cabeça. Outra característica dos Komakan são as escarificações profundas, paralelas, repetidas sobre o rosto e o torso, também encontradas nas esculturas mais antigas dos Mandê (LELOUP, 2011).

Figura 29 - À esquerda, Figura com braços levantados, Século XVI, madeira com pátina crespa, sem medidas, Coleção particular, Paris.

Figura 30 - À Direita, Figura com braços levantados, Século XV-XVII, madeira com pátina crespa, $94,5 \mathrm{~cm}$. Coleção particular, Paris. 

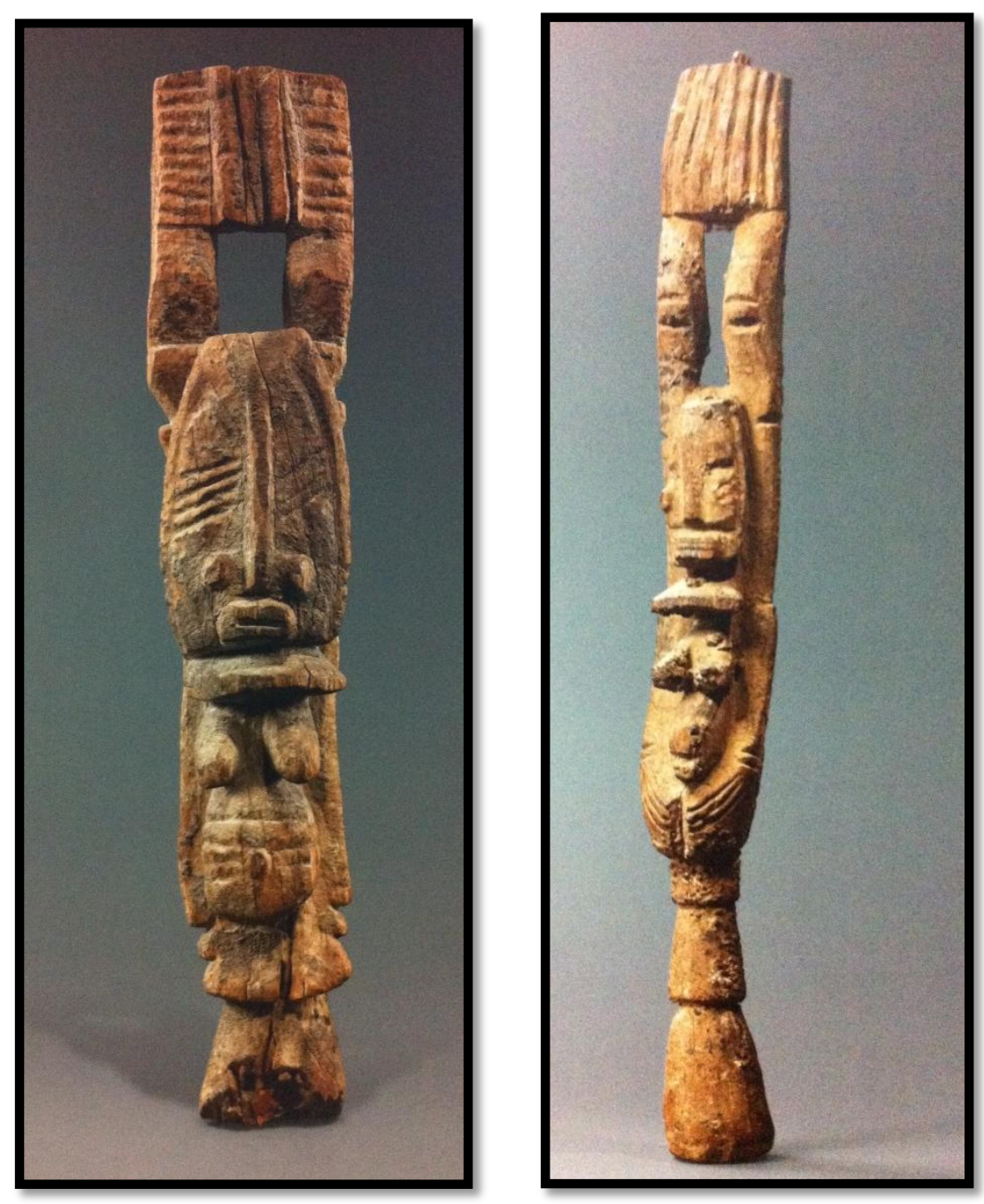

De um modo geral, pode-se dizer que as estátuas africanas, religiosas ou outras, procedem de um realismo conceitual e não um realismo visual. Por outras palavras, tratase de um realismo que não procura reproduzir fielmente os traços externos, visando antes produzir um substituto aceitável do objeto ou do personagem original, identificando-o através de símbolos e de atributos. Nessas condições, a escultura só se interessa pelas particularidades físicas do modelo na medida em que elas caracterizam atributos que the são próprios, o que, portanto, a distingue de uma representação realista e completa da presença física do modelo, tal como aquela que a arte do retrato, por exemplo, procuraria atingir. (BALOGUN, 1977).

Figura 31 - À esquerda, Figura com braços levantados, Séculop XVI, madeira e pátina grossa, $55 \mathrm{~cm}$. Coleção particular, Paris. Figura 32 - À direita, Figura com braços levantados, (s/ data), madeira e pátina crespa (s/medidas). Coleção particular, Paris. 
3.4 - ESCULTURA TELLEM
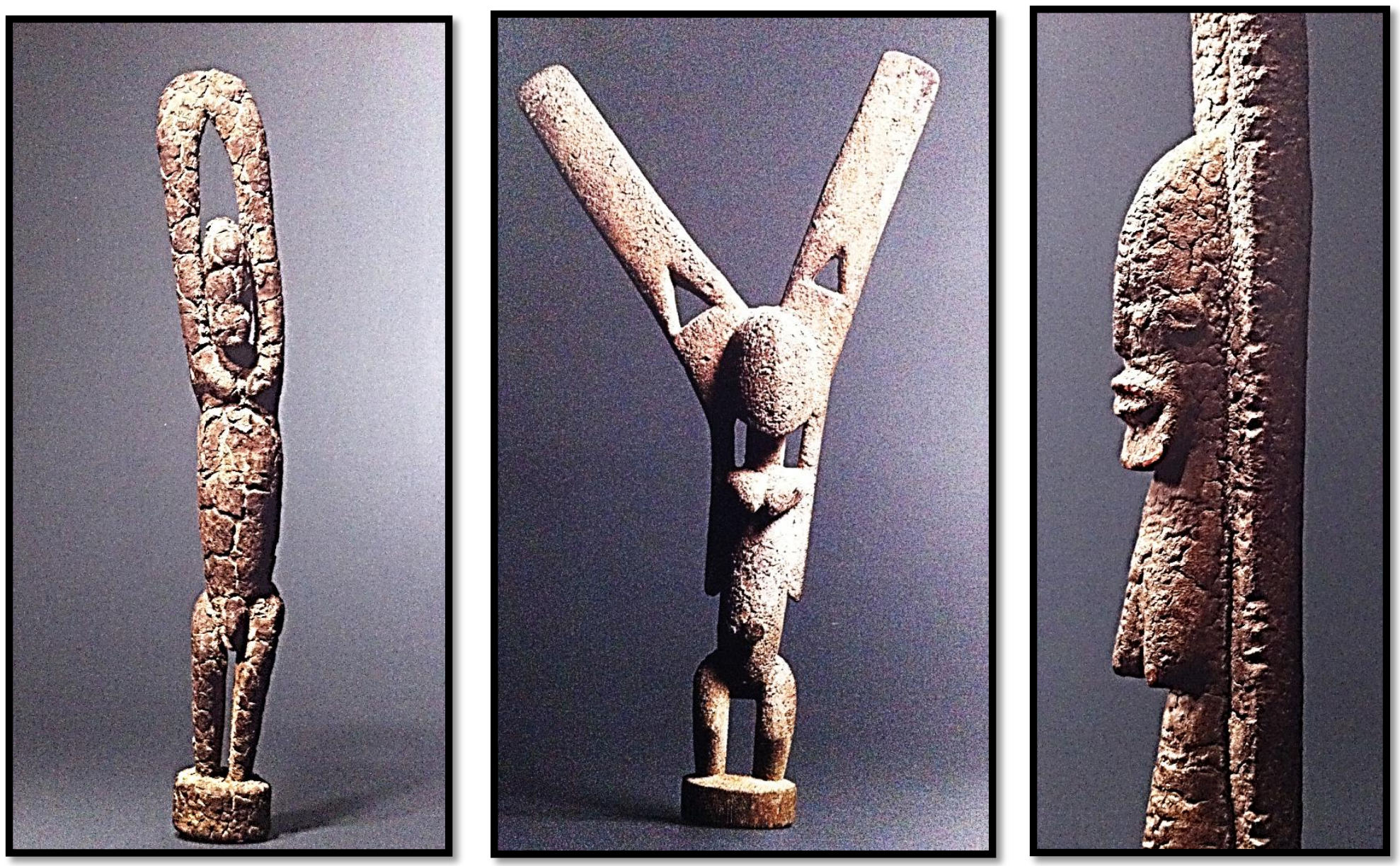

Figura 33 - À esquerda, Figura com braços levantados, Século XVI, madeira com pátina dura, $42,5 \mathrm{~cm}$. Coleção particular, Paris. Figura 34 - Ao centro, Figura Feminina, (s/ data), madeira com pátina dura, $46 \mathrm{~cm}$. Coleção particular, Paris.

Figura 35 - À direita, detalhe da Figura com braços levantados, (s/ data), madeira com pátina dura, $40 \mathrm{~cm}$. Coleção Jan-Michel Huguenin, França. 
Conhecidos como os mais antigos habitantes da África Subsaariana, os Tellem se estabeleceram sobre as pedras da falésia a partir do século $\mathrm{XI}$, utilizando as grutas como refúgio e abrigo, lugar onde montaram santuários e cemitérios. Local de difícil acesso, o arenito maciço que forma a falésia de Bandiagara não é rico em terras aráveis e, devido à acidez do solo e dos cupins, as esculturas em madeira das épocas mais antigas são extremamente raras.

As esculturas Tellem têm pequenas dimensões e são cobertas por uma espessa pátina sacrificial, crespa, espécie de crosta que cobre toda a madeira devido às várias libações - com água, sangue e mingau de milho - praticadas sobre as mesmas durante os cultos religiosos. Essa cobertura faz com que o formato dessas estatuetas, aparentemente estilizadas, aproxime-se da abstração.

São peças com cabeça volumosa, seios e umbigos ressaltados, embora não seja possível distinguir os detalhes dos dedos, dos olhos, das roupas e de possíveis sinais de escarificações por estarem cobertos pela pátina. É provável que sob a pátina possa-se encontrar a figura originalmente esculpida, o que nos levaria a identificar duplamente o estilo Tellem considerando esses dois momentos; 0 do entalhe original e sua transformação pela cobertura.

O conjunto dessas estatuetas possui uma forte unidade estilística, marcado pela verticalidade dos corpos longilíneos e esguios. As personagens inicialmente são apresentadas adotando a mesma gestualidade - braços estendidos, levantados acima da cabeça, mãos unidas - interpretadas como uma invocação à chuva.

Os Tellem são considerados pelos Dogon como os verdadeiros defensores da terra, aos quais atribuem a herança de seus saberes e rituais. Para os Dogon, Tellem significa "aqueles que por aqui estiveram". 

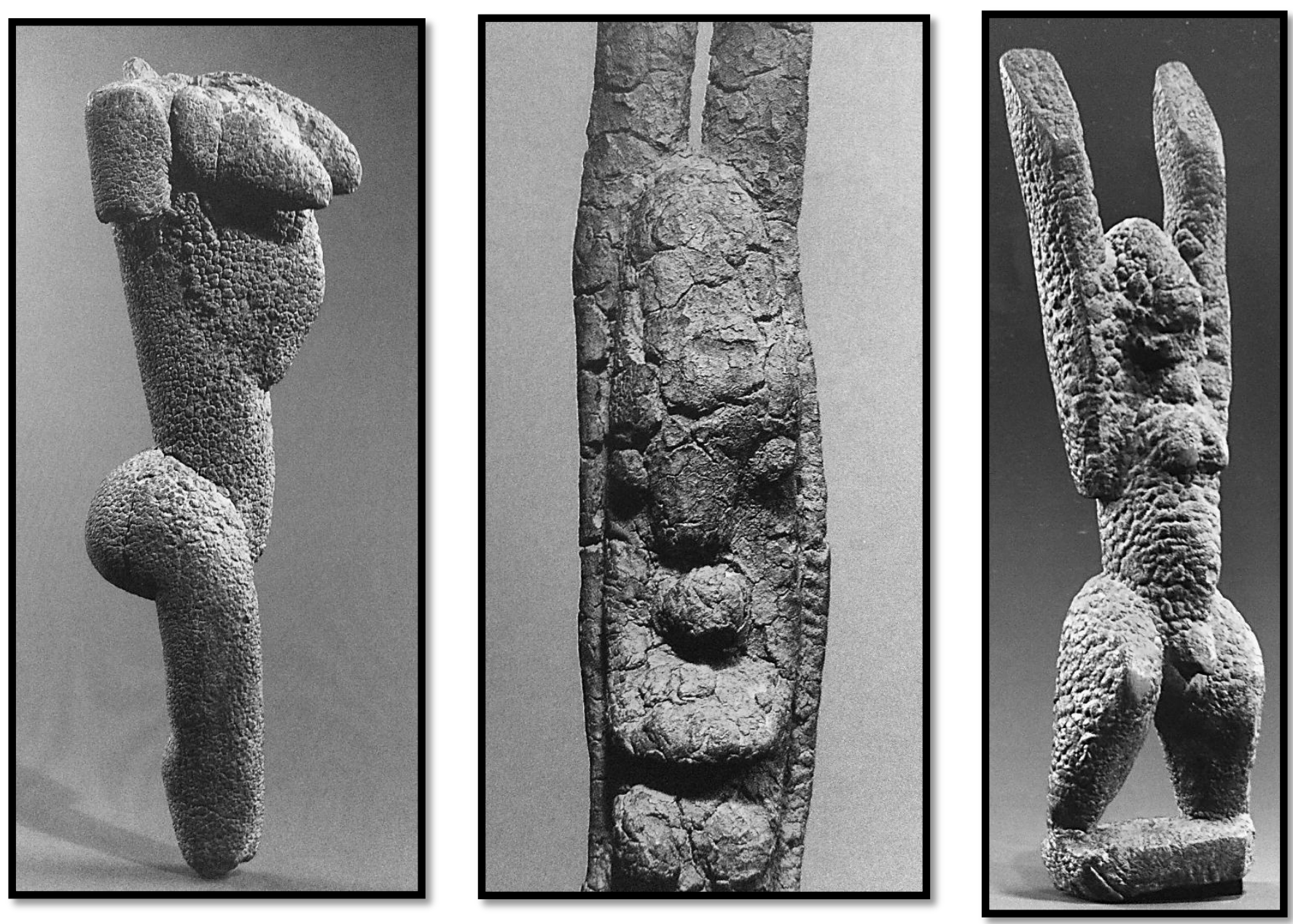

Figura 36 - À esquerda, Figura Feminina, madeira dura e pátina grossa na frente e pátina fina nas costas, Século XV-XVI, 12 cm. Coleção particular, Paris Figura 37 - Ao centro, detalhe da Figura Feminina com braços levantados, madeira dura com pátina grossa, (S/data), Coleção Particular, Paris. Figura 38 - À direita, Figura hermafrodita com braços levantados, madeira dura com pátina grossa, 
3.5 - ESCULTURA NIONGOM

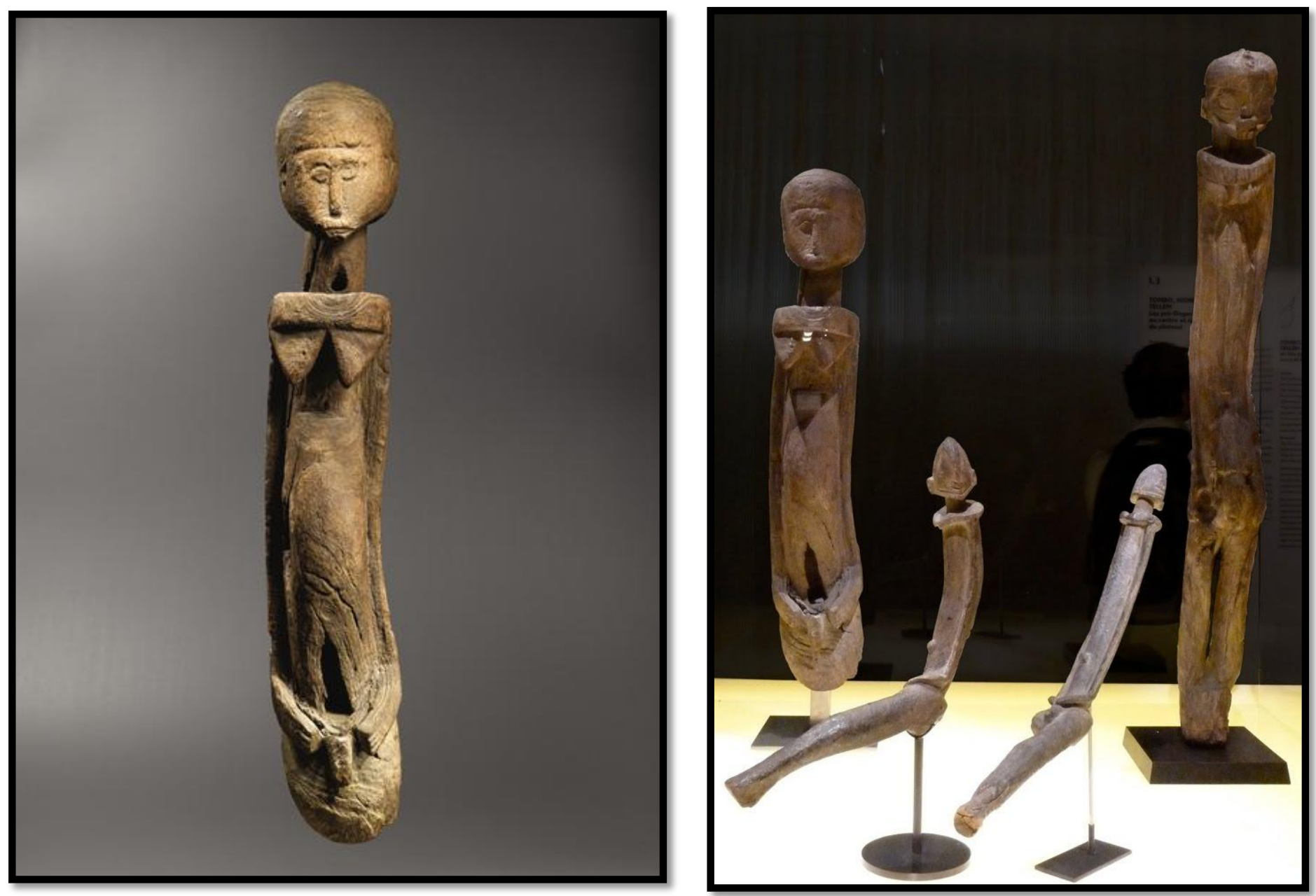

Figura 39 - Escultura Hermafrodita, Niongom, Dogon. Séculos XV/XVI. Madeira dura, patinada. Altura: $110 \mathrm{~cm}$. Coleção particular. Paris. Figura.40 - Conjunto de esculturas Niongom expostas no Pavillon des Sessions, Museu do Louvre, Paris. 
Primeiros habitantes da base da falésia, os Niongom já estavam em Bombou quando se dirigiram para o vale do Yatenga e Mandê.

As esculturas Niogom foram encontradas, na maioria das vezes, enterradas ou abandonadas. É difícil determinar a sua utilidade. As poucas peças que foram recolhidas pelas Missões Etnográficas sobreviveram graças à dureza de sua madeira.

Os Niongom identificam na madeira as semelhanças com o corpo humano e iniciam o processo de desbaste num exercício de apurada intenção artística onde preservam as formas naturais que a estrutura da madeira oferece, para entalhar apenas o necessário e configurar a escultura. As cabeças são mais detalhadas: rostos arredondados com traços acentuados, a mandíbula alargada é perpendicularmente estruturada pelo nariz em forma de seta e os olhos em formato de amêndoas.

Entre as poucas figuras do conjunto de peças desse estilo, temos a "Figura Hermafrodita do Mestre de Yayé" (figura 69), encontrada enterrada em Niongom em 1935, durante a Missão Saara-Sudão pelas pesquisadoras Denise Paulme e Debora Lifchitz. Essa escultura é uma das peças mais interessantes da arte estatuária Dogon por ter sido descoberta por acaso e trazer em si características específicas de um estilo pré Dogon como por exemplo o hermafroditismo, o formato alongado dos braços e tronco, o corte da barba e dos cabelos e a postura ligeiramente inclinada. 


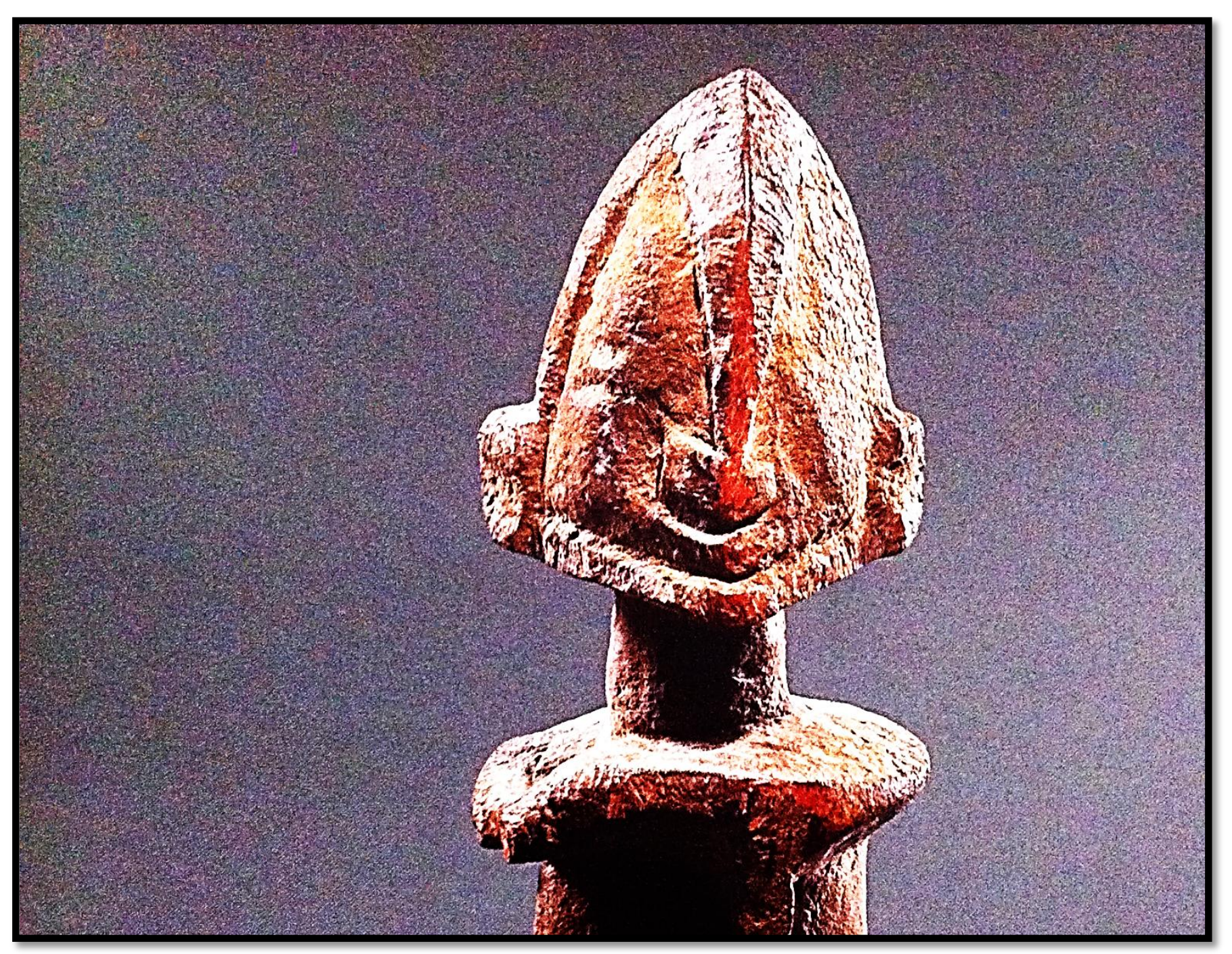

Figura 41 - Detalhe da escultura Figura, Niongom, (s/ data). Madeira dura patinada, $48 \times 61 \mathrm{~cm}$. Coleção Su e Jan Calmeyn, Anvers, Belgica. 


\section{6 - ESCULTURA BOMBOU-TORO}

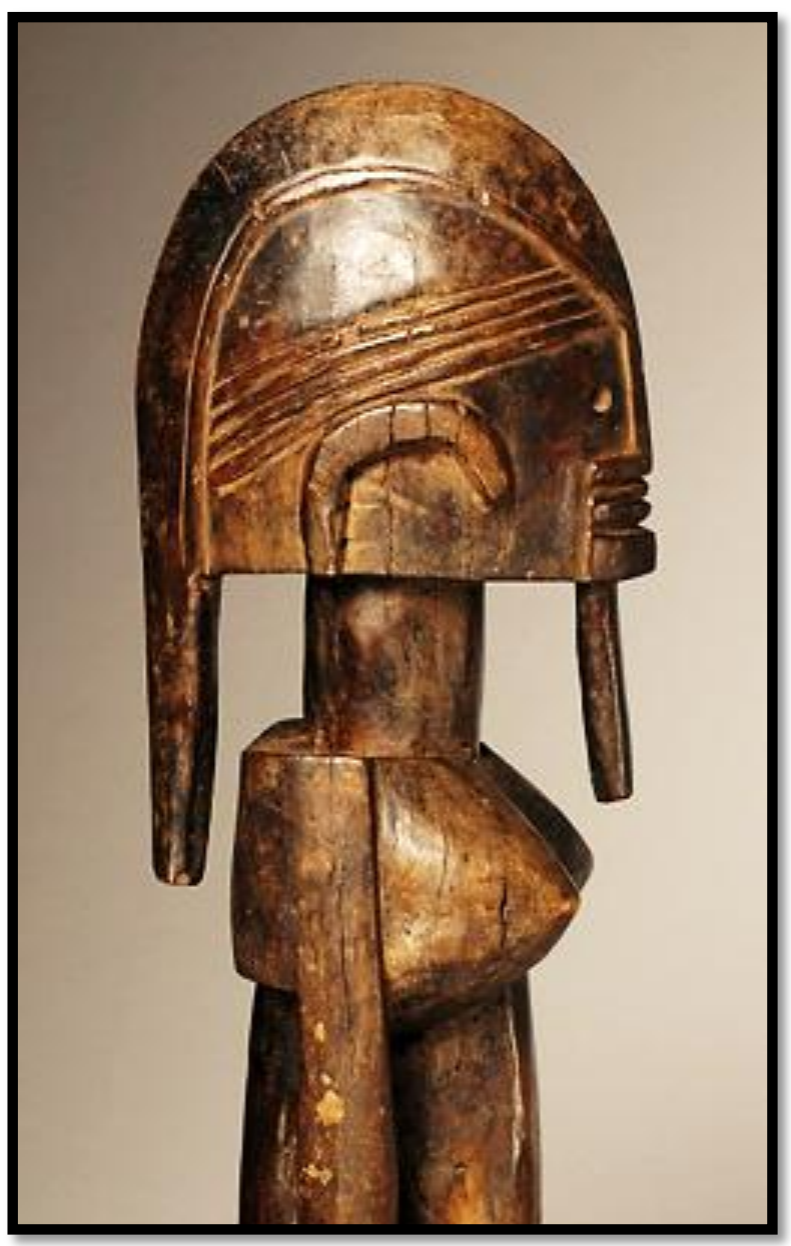

Figura 42 - Figura Feminina, atelier do mestre de Ogol (1730-1780). Terceira Missão Marcel Griaule, 1935, madeira, 70 cm, Museu do Quai Branly, Paris, França.
"Do ponto de vista da etnologia, a arte africana como todas as artes ditas primitivas é uma arte que significa; ela não representa [...] A própria essência da arte negro-africana é de significar e não de imitar; é de levar a forma que aparece na matéria a apresentar uma mensagem [...] As estátuas ancestrais (salvo raras exceções) não devem, apesar da forma humana, assemelhar-se com uma pessoa determinada. Devem ser como pessoas, mas não como pessoas determinadas. $A$ arte africana tradicional não é uma arte de imitação. É uma arte de presentificação, embora tenhamos poucos casos de representação[...] Sendo uma arte de presentificação ou de significação, ela é de fato uma linguagem e uma combinação de signos que recriam uma realidade. As esculturas africanas são manifestações diversas e precisam de grandes princípios e de ideias gerais". (MUNANGA, 2006)

Fonte: http://www.macvirtual.usp.br/mac/arquivo/noticia/Kabengele/Kabengele.asp 
A escultura Bombou-Toro está ligada à produção artística da falésia sul, santuário religioso, batizada por Fernando Lagnola como "O Vaticano Dogon”, em seu livro Voyage à Bandiagara (2009). A proximidade a esse lugar sagrado talvez justifique a numerosa quantidade de objetos com expressão e qualidade inéditas. São inúmeras figuras com troncos alongados (personagens femininas, hermafroditas, casais de gêmeos masculino-feminino), sentadas, inclinadas ou ajoelhadas. Nessas esculturas podemos notar o pleno domínio no jogo entre o cheio e o vazio, o que nos remete a alguns resultados plásticos alcançados pelos Niongom (nariz em forma de flexa, pupilas centralizadas em olhos em forma de losango e as omoplatas em relevo sobre a mesma linha dos seios suspendidos).

Aos Bombou-Toro é atribuído um conjunto de esculturas de mulheres em pé com as mãos cruzadas sobre a barriga e esse tratamento específico tem sido atribuído ao Mestre de Ogol.

A figura 43, representa uma singularidade na escultura Bombou-Toro; é uma escultura-altar com cinco faces, antropomorfa, que, ajoelhada como se estivesse em posição de oração, pode ser um receptáculo ou suporte de oferendas situadas no cruzamento das relações entre as forças divinas ou vitais em seus múltiplos aspectos: ela pode ser a presentificação de Amma, o criador; Lébé, a divindade da Terra; Nommo, o deus da água, forças de naturezas diversas e os ancestrais (LELOUP, 2011). 

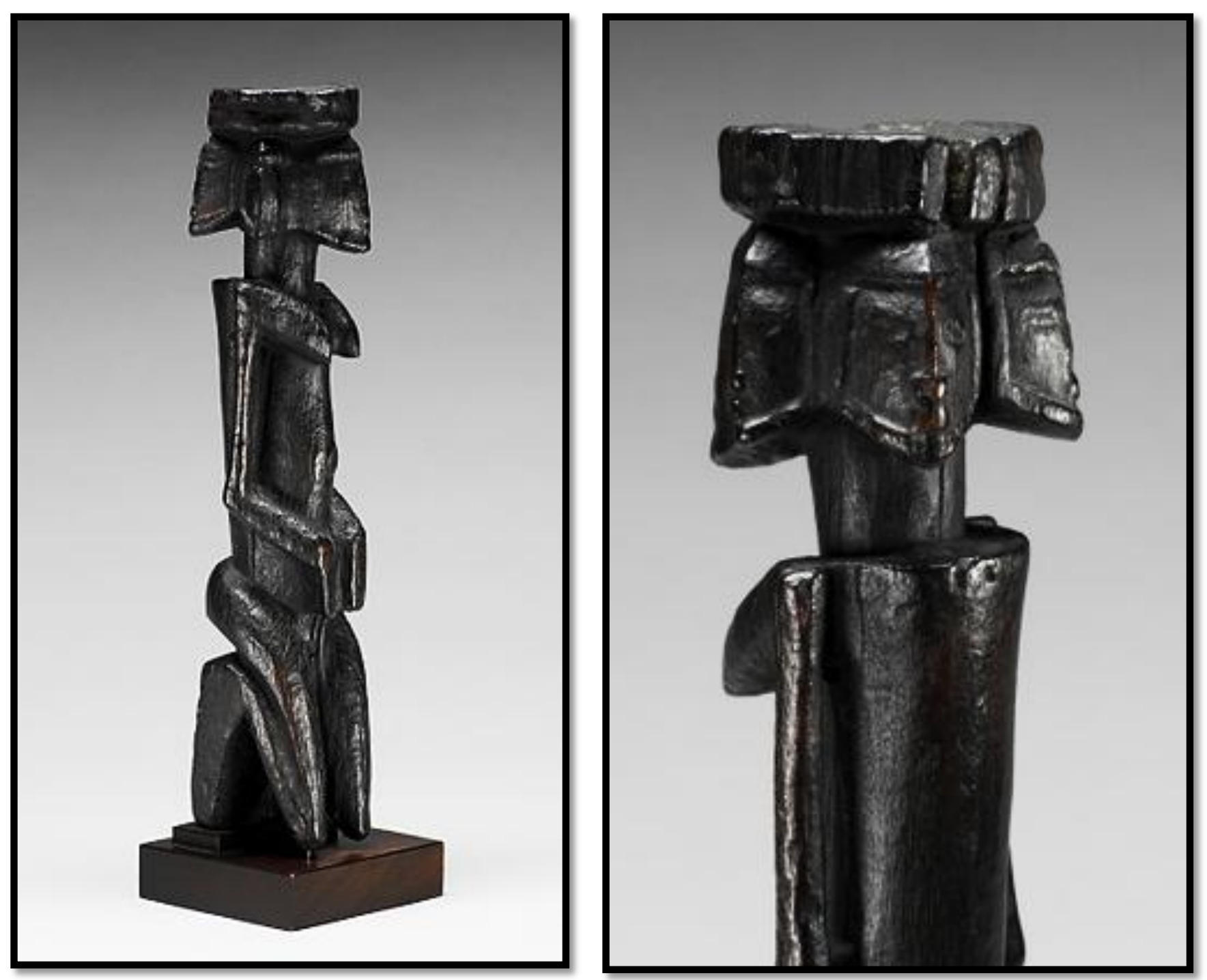

Figuras 43 e 44 - Escultura-altar com cinco faces. 1720-1780 (C 14, POZ 37888). Madeira dura patinada, 35,5×9,5×9,5cm, Museu do Quai Branly, Paris, França. Inventário 70.2003.3.1 - Antiga coleção René Rasmussen; doação, antiga coleção Hubert Goldet. 
"Por sua singularidade, ela consegue identificar a particularidade dos problemas e ativar as forças vitais por meio de oferendas de mingau de arroz, de milho ou de sangue de galinha e proporcionar uma resposta protetora. Ela está situada num nível de relações que vai do indivíduo à aldeia, passando pela família, a linhagem, a vizinhança, o clã e todos os lugares dedicados ao sagrado, altares, onde há intervenção desse material produzido pelos ferreiros-escultores. Essas esculturas caracterizam-se por uma dimensão ambivalente, negativa e positiva, que justifica uma gestão prudente do invisível. As esculturas com múltiplas faces são interpretadas como a recordação de uma visão ou um de um sonho, sua função essencial, reforçada pelo aspecto multidirecional do olhar, expressa a vigilância diante do perigo ou de uma ameaça de doença por exemplo. É possível que, à luz destas interpretações esta estátua tenha um princípio garantido, um princípio de cura. Um princípio de vigilância familiar que simboliza a solidariedade da linhagem. Com o tempo e por ter servido ao seu propósito, ela não recebe mais sacrifícios e perde os seus poderes, juntando ao panteão de imagens sobre a história de sua origem, o ancestral que justificou a sua criação" (JOUBERT, H. in LELOUP, oc.cit. p. 276). 

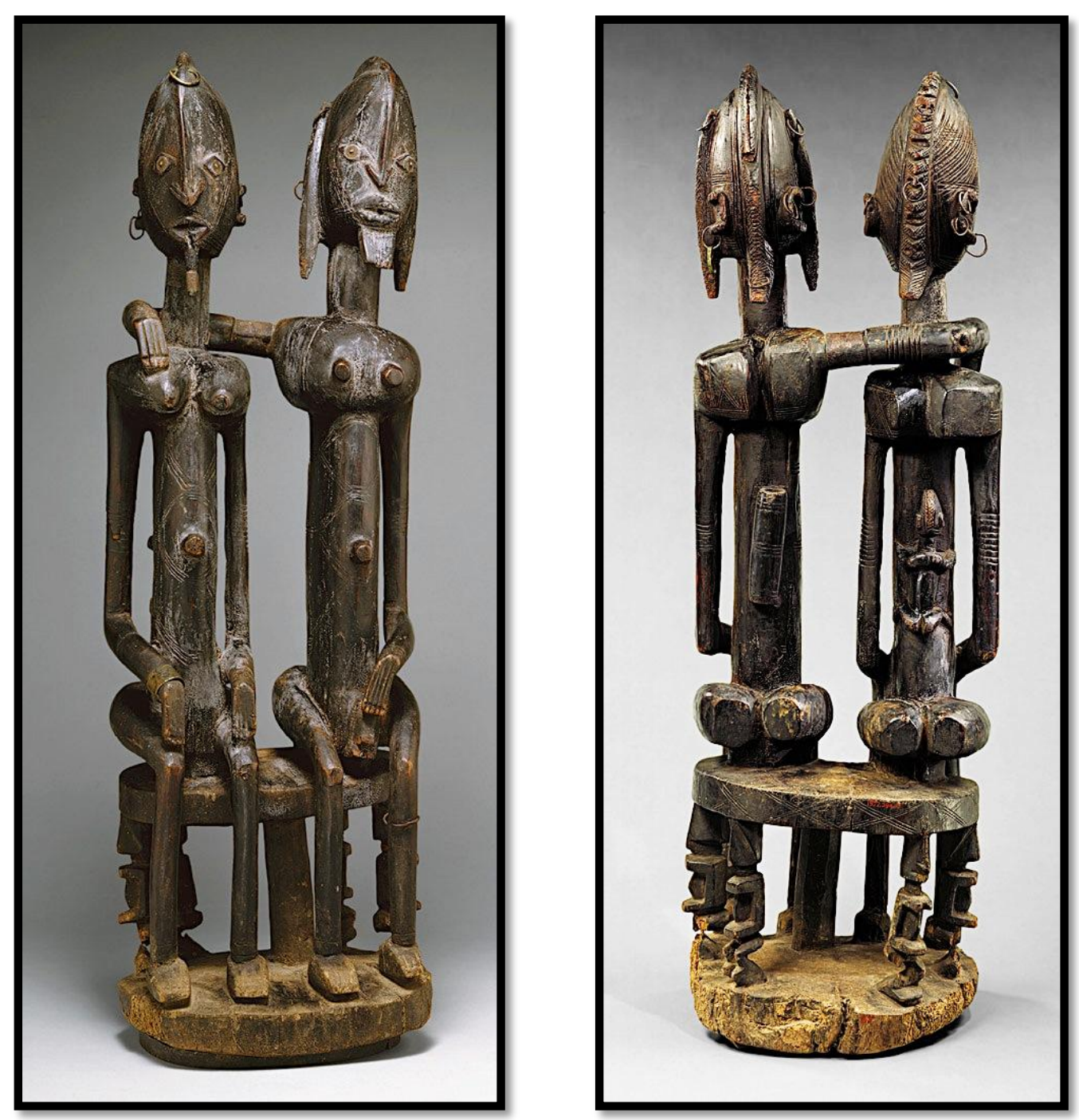

Figuras 45 e 46 - Casal sentado, de frente e de costas. Madeira e ferro, $73 \mathrm{~cm}$. (S/data). The Metropolitan Museum of Art, New York. 
3.7 - ESCULTURA TINTAM
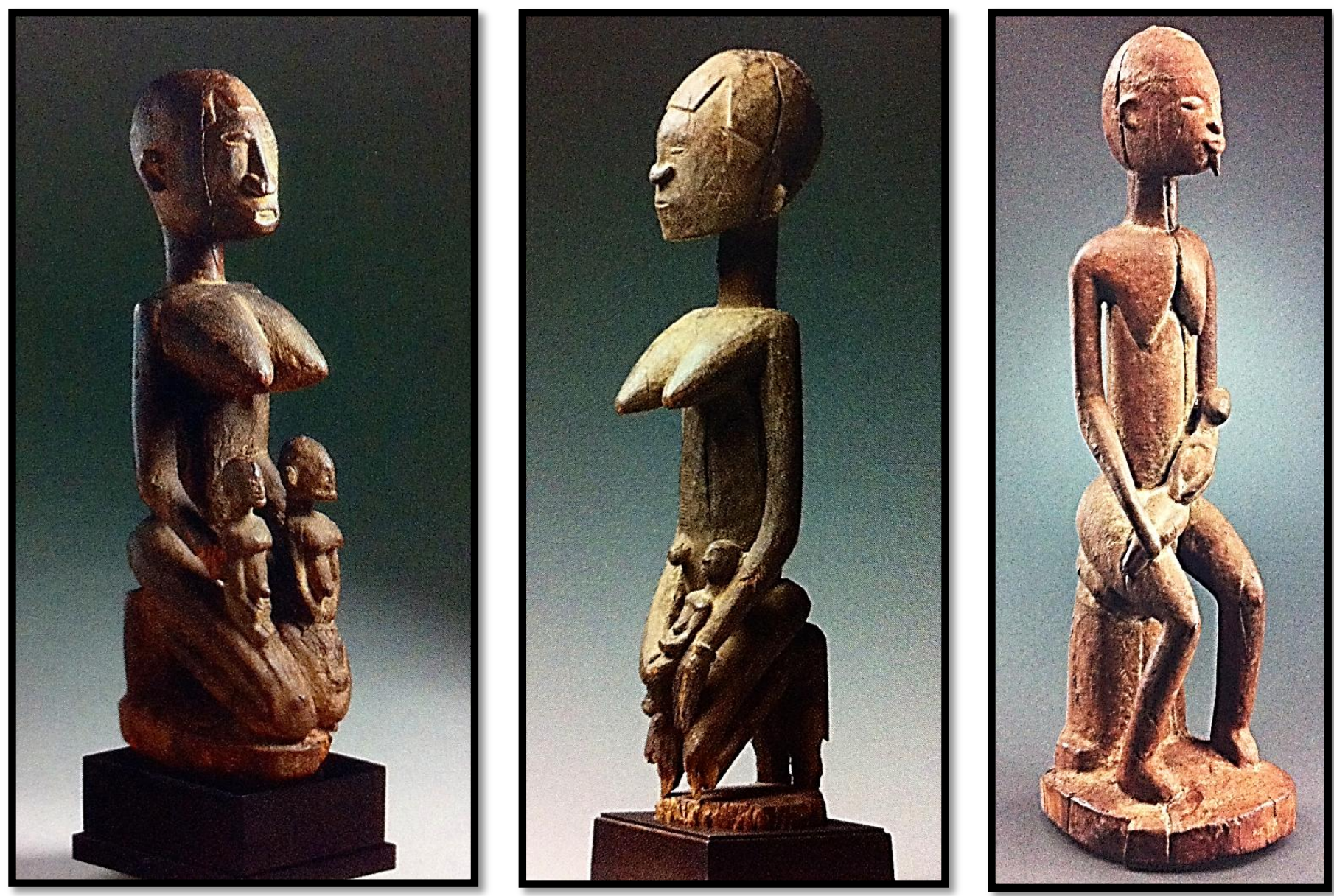

Figura 47 - À esquerda, Maternidade com gêmeos, madeira, 41 cm. Coleção Rumpj, Alemanha.

Figura 48 - Ao centro, Maternidade, $59,5 \mathrm{~cm}$. Arquivo Simonis, Dusseldorf, Alemanha.

Figura 49 - À direita, Maternidade, Mestre da maternidade vermelha, Século XIV, madeira dura, pátina vermelha, 75x20x24,5 cm. Museu do Quai Branly, 
Instalada ao noroeste do planalto, sobre um pico rochoso de difícil acesso, a aldeia Tintam está associada à criação de vários ateliers cuja estética é totalmente diferente das aldeias do sul. As esculturas Tintam podem ser definidas de várias maneiras, desde obra realista, rica em detalhes à obra geométrico-abstrata na qual a figura humana está em destaque.

A influência do Islam foi confirmada logo após a islamização dos Fulas e essas particularidades são encontradas na escultura Tintam. São esculturas de grande porte pelo fato da região onde se encontravam, Bondum, manter árvores enormes. Muitas estátuas apresentam-se com os braços erguidos, o que identifica, além da clemência pela chuva, o caráter robusto dessas esculturas. São figuras esguias, mas estruturalmente sólidas, com autoridade, demonstrando a sua força, virilidade e vigor ao mesmo tempo, contrastando com o hermafroditismo interiorizado das esculturas Bombou-Toro, por exemplo. No rosto, leva as escarificações quadriculadas dos Djennenké, tradicionais como eles, riscadas perto do canto dos olhos, como os Songhai muçulmanos (BLANC, 2011).

O conjunto escultórico dos Tintam apresenta uma série de mulheres em atividades domésticas: mães amamentando, carregadoras de água com um pote sobre a cabeça. Muitas dessas esculturas são recobertas com uma lama vermelha, cor que simboliza a energia vital. Portam tangas, colares, pulseiras e adornos nos antebraços e no queixo. Seus umbigos e glúteos são bastante ressaltados. No caso específico da figura 50-51, pode-se notar uma composição com volumes suaves, arredondados; tanto a mãe quanto a criança têm os membros afinados e não apresentam dedos. A cor vermelha está associada à vitalidade do sangue e à força vital. Os seios planos e triangulares denotam que ela é uma mulher realizada por ter amamentado. A criança é uma delicada versão em miniatura da imagem da mãe. 


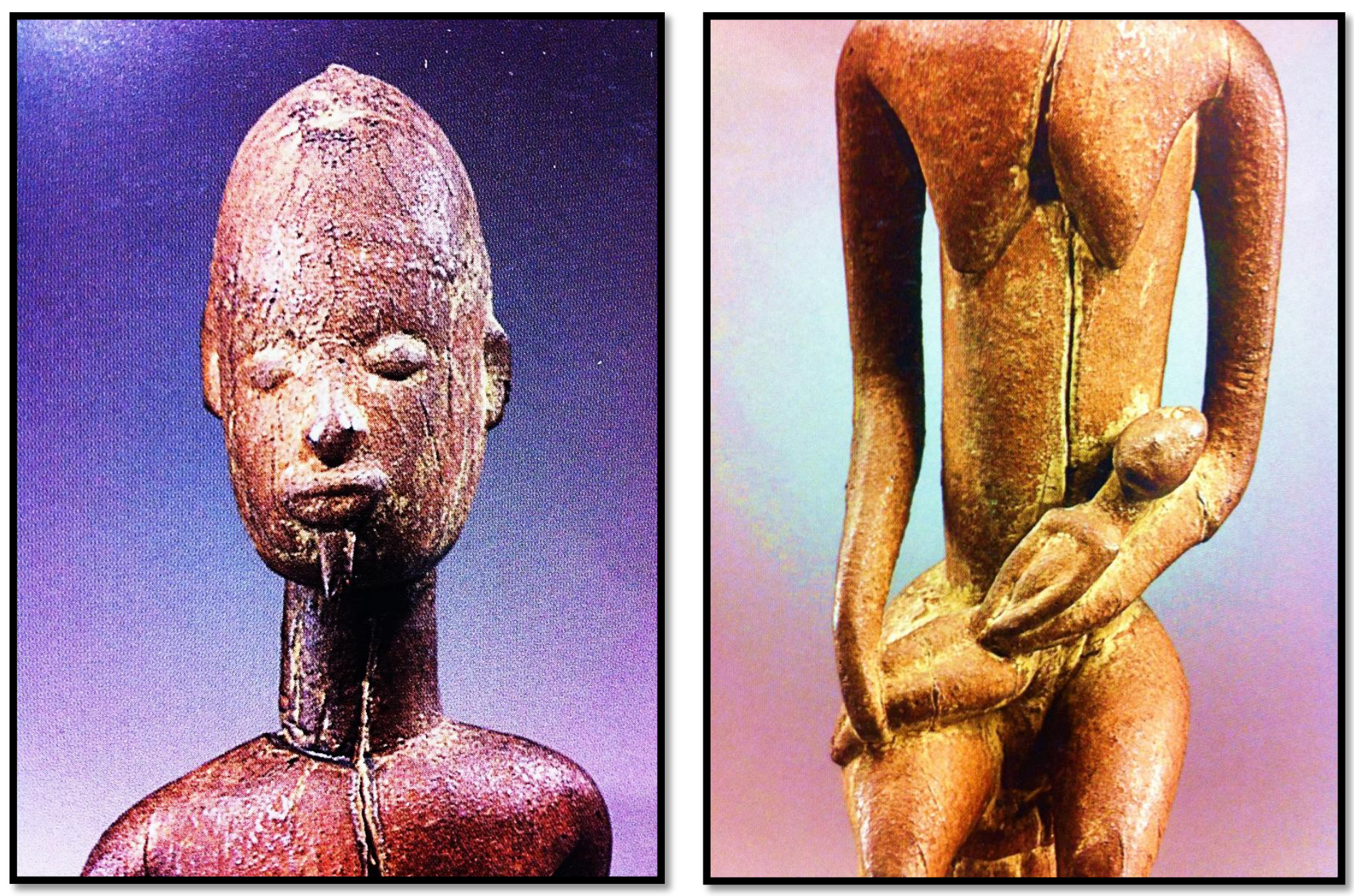

Figuras 50 e 51 - Detalhes, cabeça e tronco da escultura "Maternidade" do Mestre da maternidade vermelha, século XIV, madeira dura, pátina vermelha, pigmentos 75x20,5x24,5 cm, Museu do Quai Branly, Paris. Inv. 70.1999.9.3 . Antiga coleção Maurice Nicaud; doação antiga coleção Hubert Goldet. 


\section{8 - ESCULTURA N'DULERI}
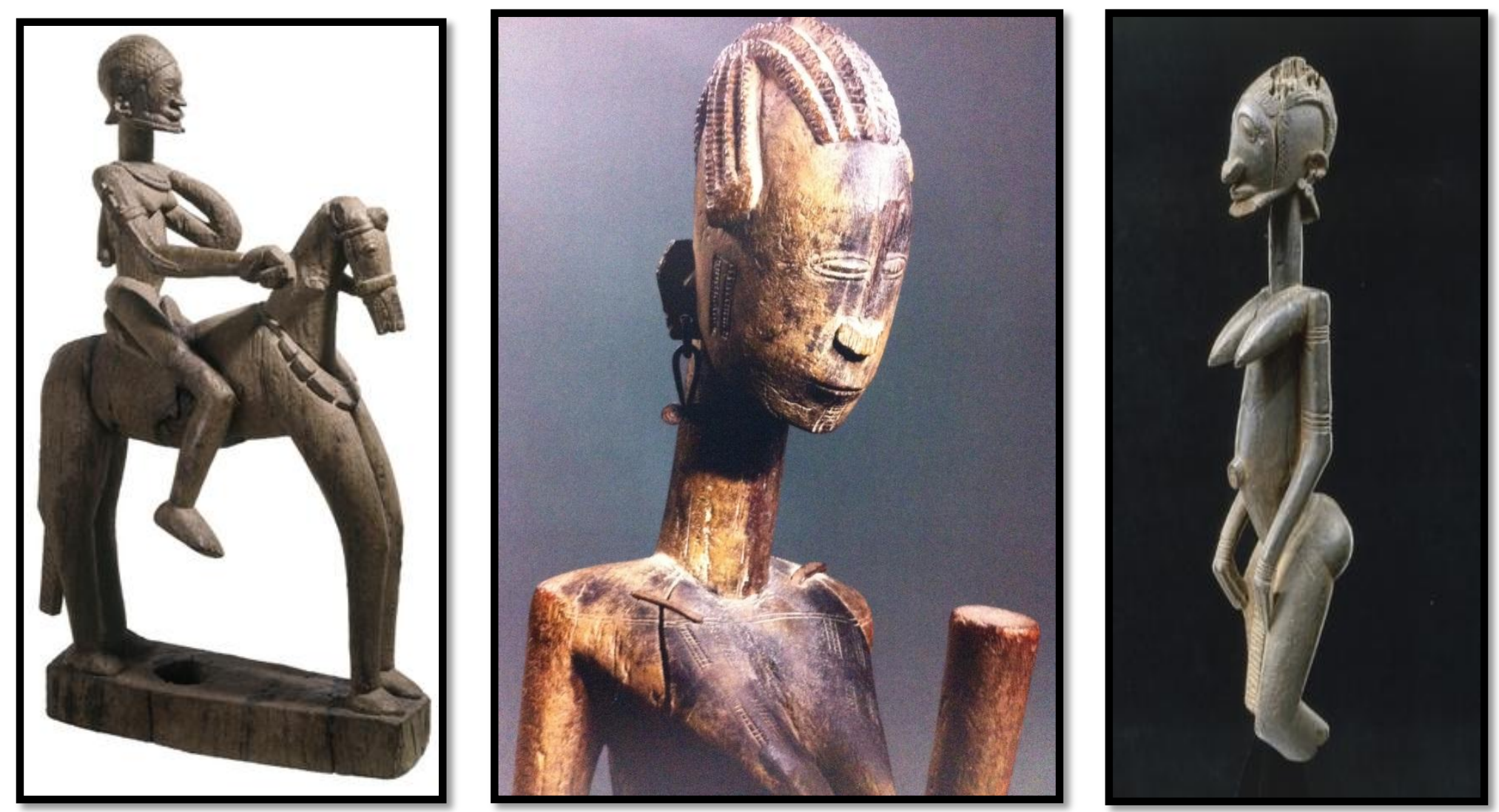

Figura 52 - À esquerda, Cavaleiro, madeira, século XVI-XVIII, 90,8×25,4x47,3 cm. Coleção particular, Paris.

Figura 53 - Ao centro, Detalhe da Piladora de milho, Século XVI-XVII, madeira dura ornamentada e peças de restauração indígena em ferro, $110 \mathrm{~cm}$. C. Part. Paris. Figura 54 - À direita, Figura feminina, Mestre dos olhos oblíquos, século XVII-XVIII, madeira e metal, 59x13×15,5 cm. Museu do Quai Branly, Paris. 
As mais antigas esculturas do estilo N'Duleri são do século XVI e perduraram até o século XX. Descendentes dos Djennenkés, os N'Duleri desenvolveram uma civilização distinta, permitindo a eclosão de uma escultura de entalhe refinado.

A influência da estatuária Djenennké é visível em obras mais recentes da estatuária N'Duleri, onde nota-se a grande habilidade para a representação das texturas e dos panos bordados, além das escarificações quadriculadas. Entretanto, existem outras esculturas que se diferem desse modelo: figuras sem roupas, com menos escarificações - apresentando um certo realismo, semelhante ao da estatuária Dejnnenké - estão cada vez mais elegantes, grandes e com formas mais flexíveis.

Entre os N'duleri havia uma tradição de produção da imagem de homens e mulheres importantes, que eram guardados como memória, as quais, às vezes eram feitos por artistas de renome.

Existe uma unidade estilística própria da escultura dessa região pela qual se conserva a elegância longilínea herdada da arte Djenennké, mas que se diferencia por uma expressão mais autêntica e estilizada. Nessa linha de transformação estilística podemos destacar o caso do "Mestre dos olhos oblíquos", que tende a acentuar alguns recursos da arte Dogon: o pescoço bem mais longo, os cortes dos planos ainda mais definidos, os olhos bem inclinados são consistentes e sensuais, assim como o formato dos seios, nádegas e coxas. 


\section{9 - ESCULTURA DJENNENKÉ}
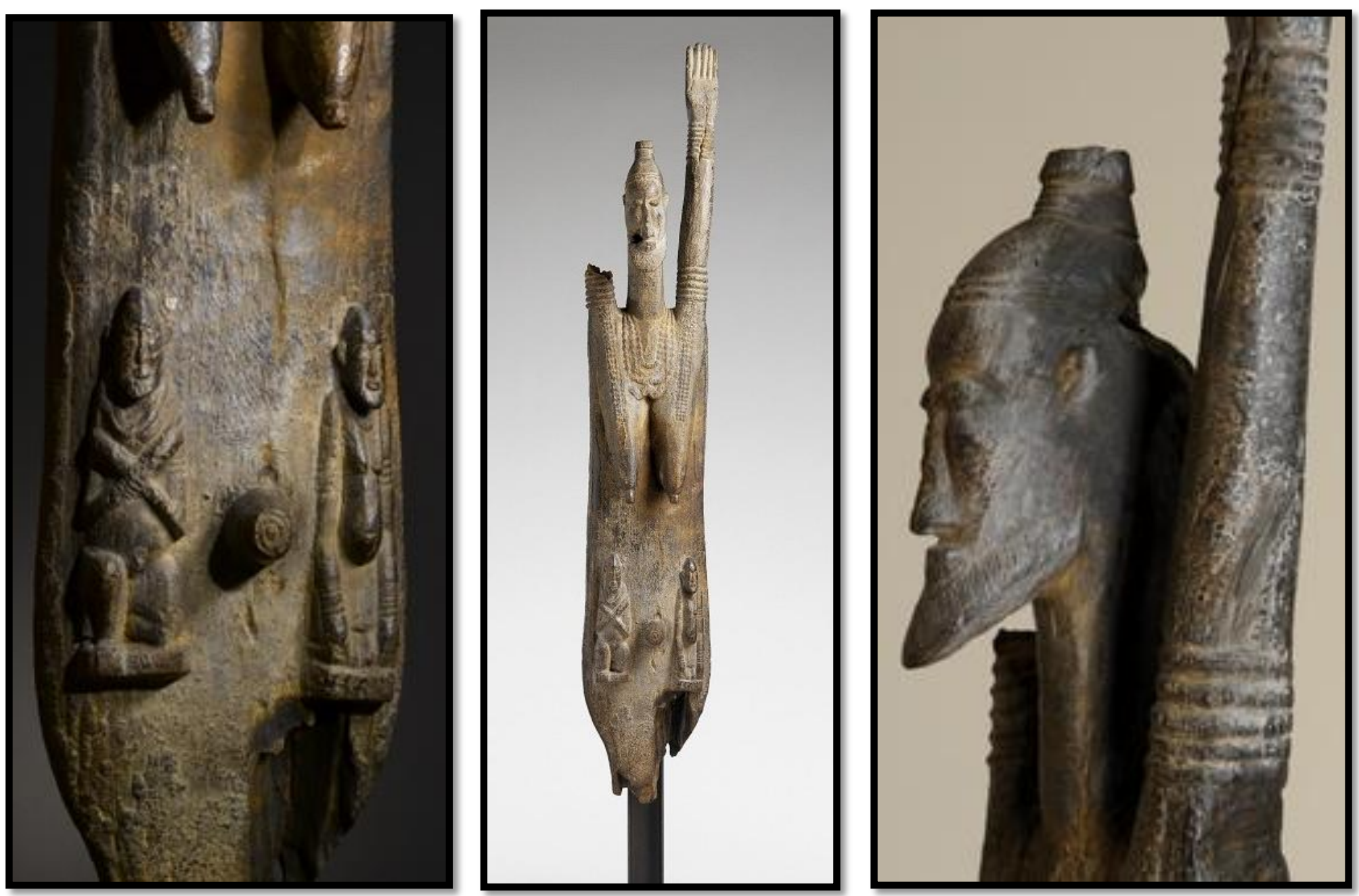

Figuras 55, 56 e 57. - Três imagens da Figura hermafrodita com os braços levantados, Século X, madeira, $210 \mathrm{~cm}$. Museu do Quai Branly, Paris. 
As esculturas Djenennké são predominantemente vazadas, verticalizadas e representam figuras humanas realistas com corpos alongados e os braços levantados. O rosto é composto por nariz afinado, olhos levemente ressaltados em formato de amêndoas. Alguns elementos são característicos desse estilo: penteados com um coque no alto da cabeça e tranças alongadas de origem berbere, barba alongada, vestindo uma espécie de tanga bordada e diversos ornamentos como braceletes e colares. Possuem escarificações quadriculadas nas têmporas, formadas por pequenos quadrados em relevo (LELOUP, 2011).

A "representação" de seres humanos e a escolha das posturas, a escultura Djenennké constitui a matriz visual e espiritual do Pays Dogon, principalmente entre os povos que os sucederam e adotaram seus desenhos e suas formas. A mitologia Dogon é a fonte dessa produção de objetos, esculpidos com a finalidade de reverenciar seus ancestrais fundadores.

Quando chegaram em Loelgeou, ao noroeste de Bandiagara, os Djenennké se dispersaram para o leste e o sudeste. Em N'dureli, seus descendentes criaram um novo estilo de escultura. A influência estilística Djenennké é perceptível entre os outros tantos povos e estilos do País Dogon. 

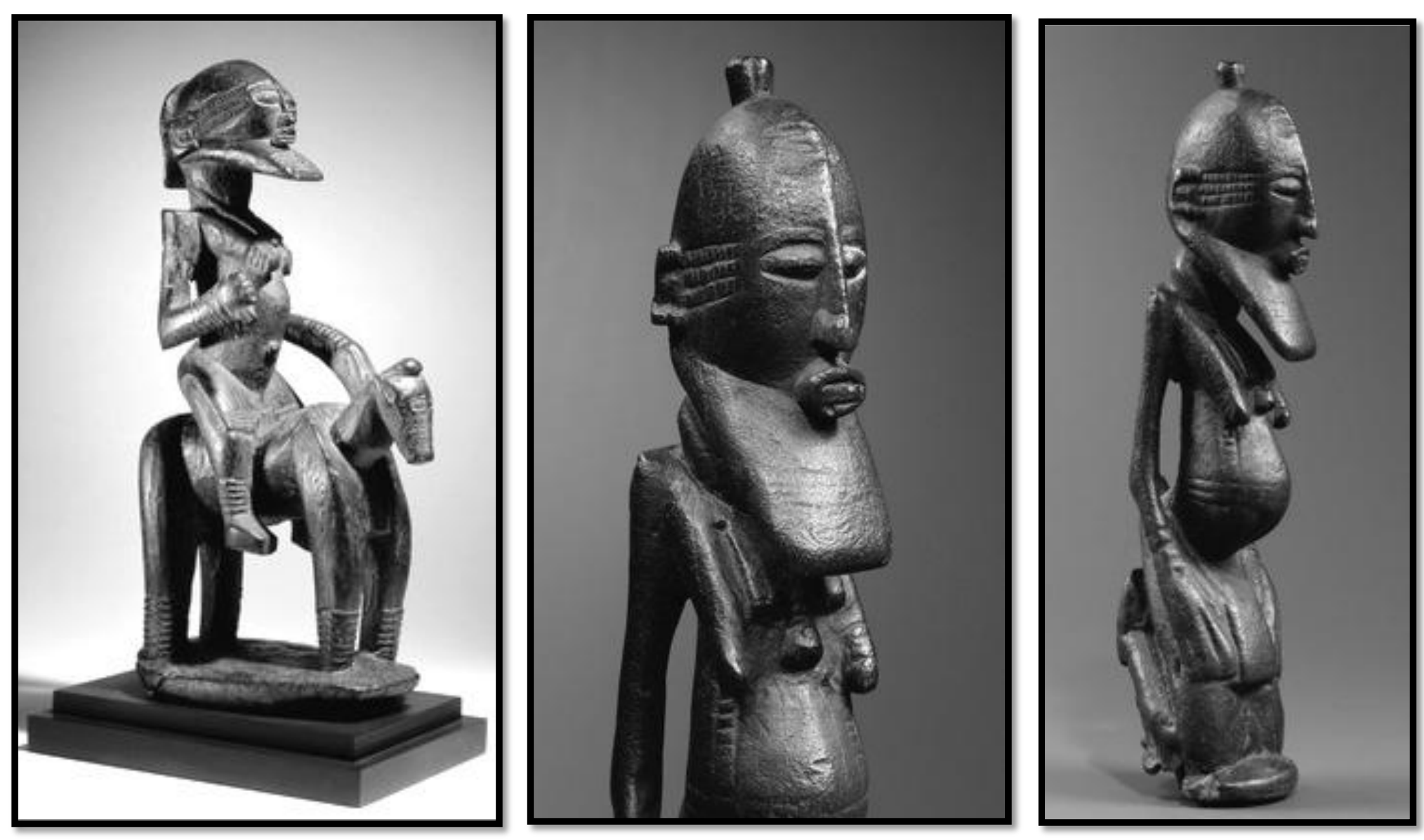

Figura 58 - À esquerda, Cavalo e cavaleiro, madeira, Século XIV-XV, 54,3X16,5 cm, coleção particular, New York.

Figuras 59 e 60 - Ao centro (detalhe) e â direita, Figura hermafrodita ajoelhada, madeira, Século XII-XIII, 31 cm, coleção particular, Champigny. 


\subsection{0 - ESCULTURA TOMBO}
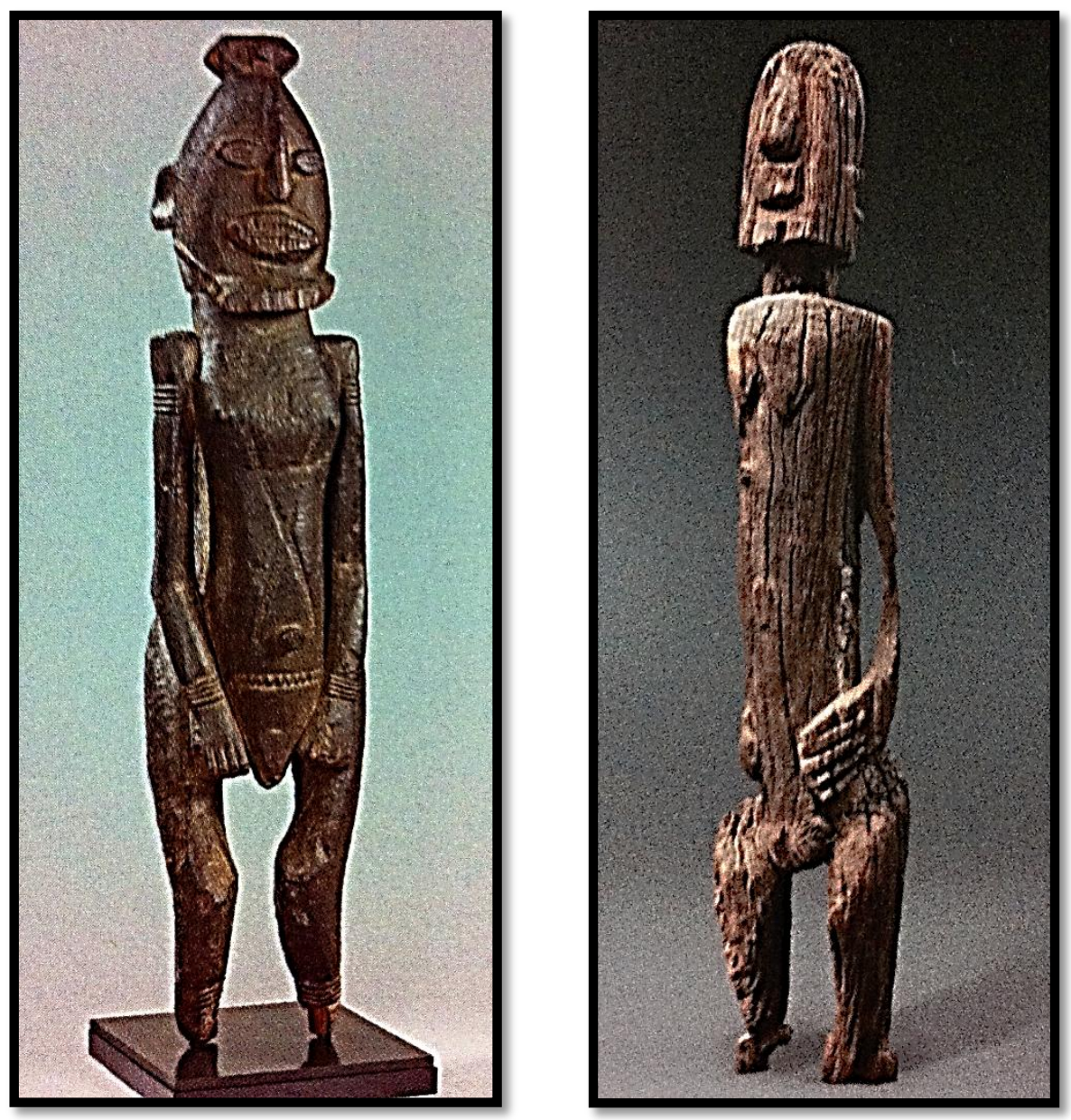

Povo pré-Dogon e conhecido como os mais temíveis guerreiros, os Tombo ocuparam grande parte do planalto de Bandiagara até a chegada dos Djenennké pelo norte e dos Mandê pelo sul. Após aceitarem a influência cultural-ancestral desses povos, seguiram para 0 norte instalaram-se numa área de difícil acesso ao norte-central. Nesse local, mantiveramse isolados e preservaram um alto grau de independência social, religiosa e estética.

Figura 61 - À esquerda, Figura Masculina, madeira, século XIII-XIV, 93×22×18 cm. Coleção Patrick e Béatrice 


\subsection{1 - ESCULTURA KAMBARI}
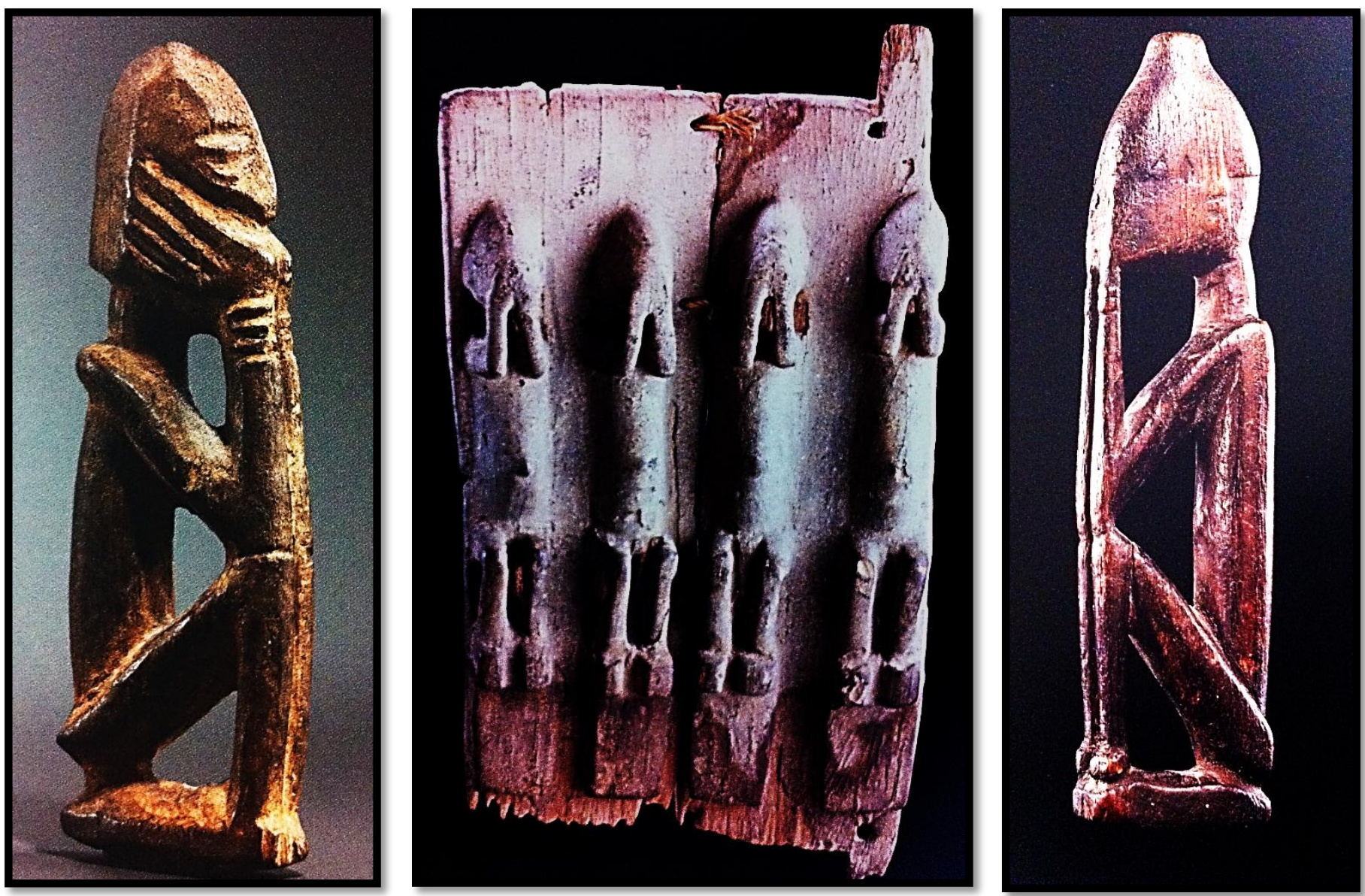

Figura 63 - À esquerda, Figura sentada com as mãos na boca. Madeira dura patinada, 12,5 cm, (S/data), Coleção particular, Paris. Figura 64 - Ao centro, Porta de celeiro, (S/data), (S/medida). Madeira, corda e pátina dura. Museu Dapper, Paris. 
A aldeia de Kambari é próxima a Bandiagara. Nesta região foi criado um tipo de escultura de tamanho pequeno e médio, sem escarificações e com formas extremamente simplificadas, o rosto redondo e os membros geometrizados.

A posição das figuras é notável; estão sentadas com os cotovelos apoiados sobre os joelhos e com as mãos sobre o rosto, cobrindo a face, numa atitude que não se encontra em qualquer outra região do Pays Dogon. Supostamente, seria a expressão de um antepassado lamentando sua incapacidade de sustentar a sua família durante um período de fome, personificando assim o sentimento de vergonha.

O fato das esculturas cobrirem os olhos, a boca ou os ouvidos com as mãos poderia ser interpretado como um símbolo daquilo que, às vezes, precisaria ser escondido, como a vergonha que capturara o primeiro homem criado por Amma logo após ter cometido o incesto com sua mãe, a Terra. A posição dos cotovelos sobre os joelhos acentua a inspiração dos escultores nesse magnífico trabalho no jogo das diagonais, entre o cheio e o vazio, quando as esculturas são vistas de perfil (BLANC, 2011). 

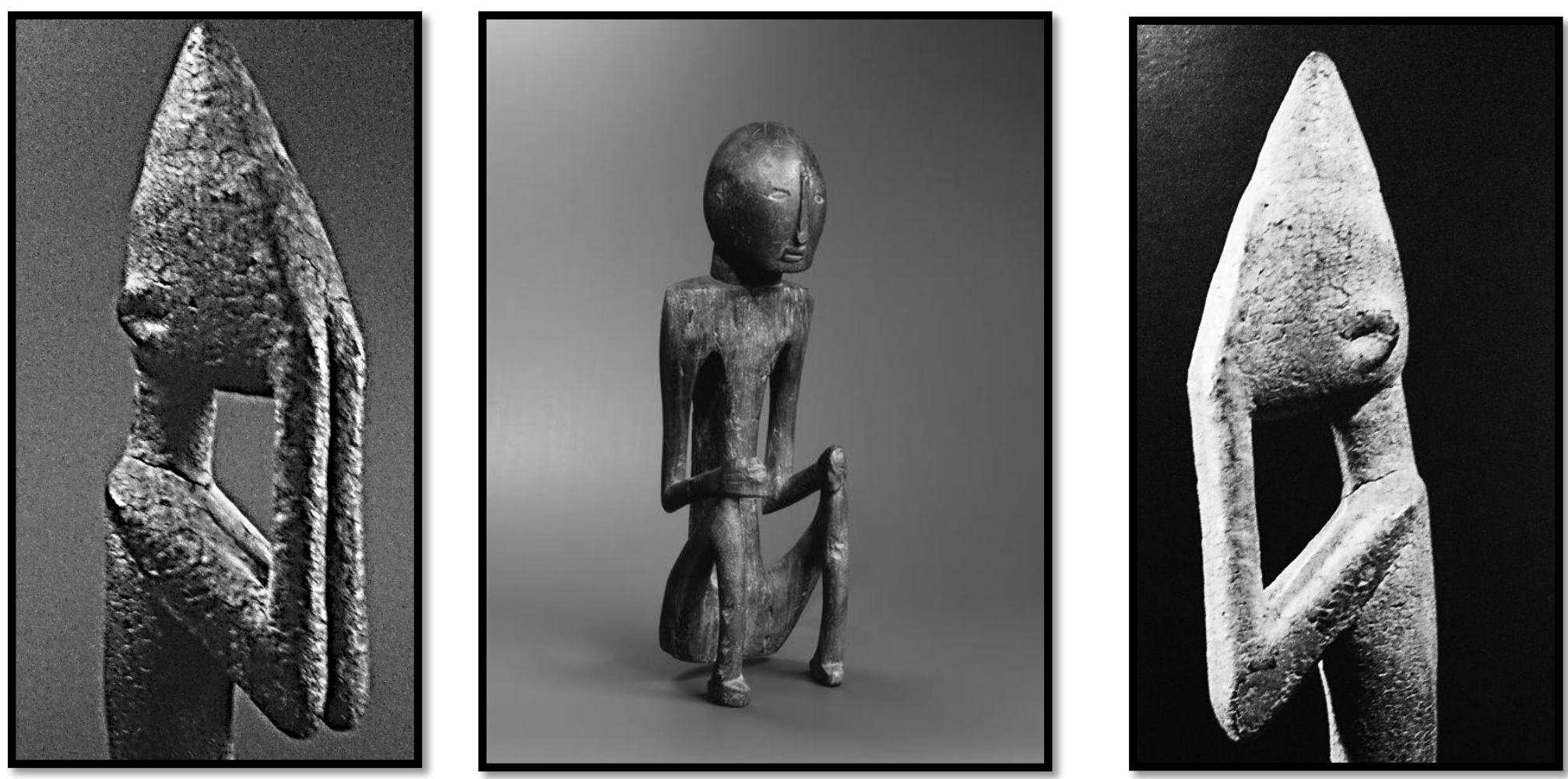

Figura 66 e 68 - À esquerda e à direita, detalhes da Figura sentada com as mãos nos olhos, madeira dura patinada, (s/data), 15,5 cm, coleção particular, Hamburgo Figuras 67 - Ao centro, Figura sentada, madeira dura patinada, 70 cm, coleção particular, Paris. 


\section{CONSIDERAÇÕES FINAIS}

A arte estatuária Dogon circula pela história da etnografia francesa desde a sua fundação até os dias de hoje, passando de objeto etnográfico à obra prima, num percurso conflituoso para os estudiosos da Arte Africana, muito mais que para os seus produtores. Sua valorização na história da arte ocidental pode ser vista como um paradigma; se por um lado há um movimento de continuidade na relação desigual de poder, pois, apesar de ser criada por grandes escultores, a arte estatuária Dogon está fixada como escultura que fala do seu primitivismo genial ou mostra uma sociedade extraordinária, ou seja, de alguma maneira é uma valorização que desloca a hipótese de que haja um desenvolvimento no interior da sociedade Dogon, que seja capaz de expressar na madeira um produto da produção humana, dentro de uma produção histórica e que tenha algo a dizer à Europa, mas não do lugar do outro, do ser inferior, do primitivo, mas, horizontalmente, no mesmo plano.

A pergunta que fica é: qual seria a dinâmica histórica que permitiu aos Dogon ou a esse conjunto de pessoas num determinado momento ter uma alta produção criativa traduzida em escultura? E como é pensada essa dinâmica criativa quando o centro é outro? Como é que ela é recuperada pela Europa? Seria a produção Dogon condenada a permanecer aprisionada à noção do primitivismo? O que separa o senso comum da construção do crítico de arte quando a coleciona e a expõe? Seria sua exposição, expressão do mundo Dogon ou do mundo Europeu em crise e em busca de novos horizontes estéticos? Contudo, quando os objetos Dogon chegam à Europa a propaganda colonial apoiava-se em uma promessa de futuro, separando-se do primitivo e apresentando-se como polo universal da 
civilização e da modernidade. As esculturas encontraram, portanto, um lugar paradoxal dentro de uma narrativa assimétrica. Como então, os artistas que reconheceram nas esculturas africanas uma fonte de renovação criativa dialogaram com elas? Tiveram que ter a sensibilidade para compreender aquela linguagem e a sua produção; veriam, por exemplo, no mestre de Yayé um colega ou outro artista? A arte africana tornou-se inspiração, modificou e impactou a arte do século XX na Europa, mas não encontrou espaço de diálogo, sendo incorporada sem o reconhecimento adequado e sem diálogo intercultural (DE L'ESTOILE).

Trabalhar a Arte Estatuária Dogon a partir de uma narrativa fixada no objeto pode ser uma metáfora da relação proposta pela Europa e o mundo ocidental aos Dogon, sendo que os Dogon aqui representam e ocupam o espaço das produções criativas, das produções históricas de uma proposta de humanidade que a relação de dominação tende a absorver e neutralizar o outro como "outro", a alteridade desse outro.

A organização da sociedade Dogon é a plena demonstração de que existe, de fato, sociedades que se desenvolveram fora da história europeia, com condições de estabelecer um diálogo de alteridades, embora esse diálogo não exista, na medida que, para que o diálogo aconteça, é preciso que se tenha dois interlocutores. Enquanto houver apenas vozes paralelas esse diálogo será impossível. Mas, a fala africana expressa na escultura em madeira, irrompe, ganha e vai além das suas próprias fronteiras, permanecendo como um objeto insubmisso.

A criação de novas propostas para a exposição desses objetos são formas atualizadas de comportá-los e entendê-los sob os paradigmas europeus, que modificam a própria visão europeia sem 
deixar de ser europeu. Assim, como é que os objetos africanos ganharam a Europa e qual é o lugar deles desde o início até o momento atual? Como é que ele chega e vai para as reservas técnicas e transformam-se em objetos da composição dos monumentos?

Os monumentos são os "lugares de memória" europeus, depois da desconstrução desses monumentos, esses lugares demonstram a vontade que a Europa tem de transformar a sua própria memória e de criar uma outra narrativa para a sua própria memória.

O conceito da Yayé vai mudando a partir do momento que ela sai do Trocadero e vai para o Louvre e também quando ela vai pro Quai Branly. O Quai Branly é uma forma europeia de buscar renarrar ou narrar diferentemente um processo da colonização onde a colonização em si desaparece e se torna abstrata ou é colocada numa disciplina. É muito interessante a narrativa do Quay Branly: é a antroplogia que participou do fato colonial, não as artes. Estas teriam finalmente reconhecido seu lugar pela transformação do conceito de primitiva para primeira, pela criação de um ambiente esteticamente contemporâneo para expor os objetos criados por sociedades e artistas de África, Américas e Oceania. O Trocadero foi o museu das coleções organizadas e narradas pelas ciências humanas como espaço para o estudo do Outro, o Quay Branly é o ambiente privilegiado dos profissionais da arte, os quais explicitam intensões de construir um discurso estético pretensamente novo, desligando-se da história colonial e suas assimetrias de poder e econômicas, sem, no entanto, deixar de ser uma narrativa centrada na Europa e sem estabelecer diálogos, conforme enfatizou Aminata Traoré (TRAORÉ, 2006 ).

A Yayé permanece ativa na medida em que ela rompe com o espaço lá onde ela foi desenterrada e vai ganhar outras vidas. Mesmo que a escultura continua sendo a mesma, seja a exposta no 
Trocadero, no Louvre ou no Branly, nota-se que ainda há uma grande mudança, uma mudança geral que atinge o universo carnal, no terreno dessas peças, que se distanciaram a partir do momento que elas tiveram contato com a estética e foram analisadas como forma, mas, ainda não conseguimos ver nenhuma nota de rodapé sobre elas. O que vemos é a origem da peça, o lugar aonde está, se era uma peça de ritual ou não. Portanto, a Yayé é uma evocação de um tipo de humanidade, de prática social que escapa às descrições habituais. Essa lacuna na narrativa sobre a peça na exposição DOGON, nos catálogos e na explicação da peça colocada pros visitantes deixa visível a sobrevivência do antigo no novo, portanto, a sobrevivência daquilo que move certo pensamento colonial, podendo ou não estar presente ali, modifica sem romper com a verticalidade na relação com a assimetria de poder e de criação de mundo, mas, também não se pode negar que a Europa se debruçou sobre o conhecimento acerca da estatuária Dogon e a estatuária Africana, avançando no sentido de que as pesquisas foram feitas e as regiões de produção foram mapeadas. É importante resgatar a historicidade do conhecimento para que permaneça a questão das formas atuais da própria sociedade Dogon de expressar a sua criatividade.

Junto com a história da Yayé, como num pano de fundo, está a história da museologia na França. Inicialmente a Yayé será exposta num dos mais importantes museus coloniais, o Trocadero, seu paradigma. Em seguida ela irá para o Louvre, quando já se começa a discutir as artes primeiras e a ideia de que há obras primas, sendo que o importante é entender que a produção africana não é uma produção primitiva, mas que a África produz obras primas, mesmo que essas obras primas tenham sido classificadas pelos europeus e algumas delas conquistem a possibilidade de serem expostas juntas com as peças do Egito. A partir disso, abre-se o debate sobre "como é?" e "o que é?" o Quai Branly, 
havendo a necessidade de refundar o discurso e criar um novo conceito: "da arte primitiva à arte primeira", onde a arte primeira continua levantando questões e o outro lado ou prisma dessa história é pensar a circulação comercial, a história da movimentação econômica que essas peças vão gerar em termos de circulação dentro e fora da Europa desde a chegada desses objetos.

Aqueles objetos que migraram para os grandes centros urbanos, para os grandes museus, eles também exercem uma influência sobre o conjunto de objetos que estão nas exposições, feiras e galerias, mesmo os que estão em poder de colecionadores privados. A Yayé é uma espécie de sustentáculo dessa narrativa europeia porque é preciso dar conta dessa massa de objetos garantidos pela sua referência.

Uma outra questão é a discussão em torno da devolução das peças para a África, quando o que se vê é a proliferação, a criação e o surgimento de museus locais. Museus de aldeias, como se isso fosse a forma do colonialismo explicar, na maneira europeia, a questão do entrelaçamento de mundos. Ou seja, se a Yayé voltasse para um museu em Bamako, ela voltaria pra onde? Que símbolos são esses que estão postos em movimento e cria valor? Cria valor pra quem? Como é que o movimento dessas peças exerce influência ou algum papel na história da criatividade e na inscrição dos Dogon no seu próprio espaço no mundo, como autores, como sujeitos da história?

A modernidade da Yayé é uma modernidade dependente de uma narrativa que é sempre uma narrativa do mesmo. A Yayé, a arte estatuária Dogon e a Escultura Africana precisam ser entendidas como algo que afirma-se no mundo presente, numa relação que não seja marcada pela dependência. 


\section{REFERÊNCIAS BIBLIOGRÁFICAS}

BALANDIER, G. Antropo-lógicas. Cultrix, Edusp. São Paulo, 1976.

BALOGUN, O. Formas e expressão nas artes africanas. In: ALPHA, Sow. Introdução à cultura africana. Lisboa: UNESCO/Edições70, pp. 27- 94.

BARROS, D.D. Itinerários da Loucura em territórios Dogon. Ed. Fio Cruz. Rio de Janeiro, 2004.

BLANC, D. L'Harmonie au monde. In: Dogon, Revue Connaissance des arts (hors-serie) Musée du Quai Branly. Paris, 2011.

BOUJU, J. La statuaire Dogon au regar de l'antropologie. In: PAUDART, C. Et al. (Orgs.) Dogon: XVXVII siècles. Paris: Museé Dapper, 1994.

BRUMANA, F.G. O Sonho Dogon: nas origens da etnologia francesa. São Paulo: Edusp, 2011.

CANCLINI, N.G. A Sociedade sem relato: Antropologia e Estética da Iminência. Edusp. São Paulo, 2012. 
CLIFFORD, J. Poder e diálogo na etnografia: a iniciação de Marcel Griaule. GONÇALVES, J.R.S.(org.) In A experiência etnográfica: antropologia e literatura no século XIX,pp. 180-226. Rio de Janeiro: Editora UFRJ, 1998.

DE L'ESTOILE, B. Le goût des Autres. De l'Exposition coloniale aux Arts premiers. Flammarion. Paris, 2010.

GRIAULE, M. Masques Dogon. Paris: Institut d'Ethnologie, Museé de l'Homme, 1938.

GRIAUle, M. e DIETERLEN, G. Le Renard Pâle. Institut d’Ethnologie. Paris, 1965.

LAUDE, J. Le sens de la forme, une approche des arts dogon. In: PAUDART, C. Et al. (Orgs.) Dogon: XV-XVII siècles. Museé Dapper. Paris, 1994.

LEIRIS, M. A África Fantasma. São Paulo: Cosac Naify, 2007.

LELOUP, H. Dogon. Paris. Somogy Éditions d’Art. Musée du Quai Branly, 2011.

LOPES, T. Sistema de arte na África. In : História da Arte: ensaios contemporâneos /Org.: Marcelo Campos, Maria Berbara, Rocerto Cunduru, Vera Beatriz Siqueira. EdUERJ. Rio de Janeiro, 2011.

MUNANGA, Kabengele. Arte afro-brasileira: o que é afinal? In: Mostra do

Redescobrimento: arte afro-brasileira = Afro-Brazilian art (Catálogo). São Paulo: Associação

Brasil 500 Anos Artes Visuais: Fundação Bienal de São Paulo, 2000. p. 98-111.

PAULME, D. Organisation Sociale des Dogon. Paris. Editions Jean-Michel Place, 1940. 
PRICE, S. Arte primitiva emcentros civilizados. Editora UFRJ. Rio de Janeiro, 2000.

RUBIN, W. Primitivism in 20th. Century Art. Museum of Modern Art, vol. 1. New York, 1984.

SILVA, D.M. ; CALAÇA, M.C.F. Arte africana e afro-brasileira. São Paulo: Terceira Margem, 2007.

\section{WEB BIBLIOGRAFIA:}

http://etudesafricaines.revues.org/,

http://www.arteafricana.usp.br/,

http://www.africultures.com/php/,

http://www.afroasia.ufba.br/index.php,

http://www.persee.fr/web/guest/home,

http://www.scielo.br/scielo.php?pid=S0104-71832008000100009\&script=sci arttext

http://www.vub.ac.be/BIBLIO/nieuwenhuysen/african-art/african-art-collection-statues.htm

http://www.quaibranly.fr/,

http://afrologia.blogspot.com.br/

http://www.dapper.com.fr/, 
http://www.museums-of-paris.com/musee fr.php?code=342,

http://www.gestress.be/rando/MaliDogon.htm,

http://rcfilms.com.sapo.pt/espelho.html,

http://hupomnemata.blogspot.com.br/2010_03_01_archive.html,

http://inton.over-blog.com/article-696638.html,

http://en.wikipedia.org/wiki/Bandiagara,

www.wpmap.org/wp-content/uploads/2012/04/political-map-of-Mal

http://www.casadasafricas.org.br/wp/wp-content/uploads/2011/08/Por-dentro-e-ao-redor-da-arteafricana.pdf

\section{VIDEOGRAFIA:}

SELIGMANN, G. - DVD, Les Dogon, chronique d'une passion, Arte vídeo, França, 2006.

BARROS, D. - DVD, Dogon, Niantao, Antares Multimeios, Brasil, 2004. 